CONSELHO NACIONAL DE DESENVOLVIMENTO CIENTíFICO E TECNOLOGICO (CNPq) INSTITUTO NACIONAL DE PESQUISAS DA AMAZÔNIA (INPA)

\title{
Anatomia foliar de Bromeliaceae da Campina
}

Marilene Marinho Nogueira Braga INPA - Manaus

ACTA AMAZONICA Vol. 7(3): Suplemento 
BRAGA. Marilene M. N.

Anatomia foliar de Bromeliaceae da campina. Acta Amazonica, Manaus, 7(3) : Suplemento jul., 1977.

74p. ilust.

1. Bromeliaceae - Anatomia foliar 2. Bromeliaceae - Aspectos ecológicos 3. Bromeliaceae - Aspectos fisiológicos I. Título.

CDD $581.497 \quad 18 . e d$

CDU 581.45

RESUMO: Foi feito um estudo anotômico-foliar das seguintes espécies de Bromeliaceae de uma campina da Amazônia Central: Aechmea mertensii, Aechmea setigera, Ananas ananessoides, Streptocalyx poeppigii, Tillandsia adpressiflora e Vriesesea splitgerberi. Por meio de cortes histo!ógicos, epidermes dissociadas e raspagens das superficies foliares de várias regióes đa folho, foram feitas descriçốes das estruturas foliares acompanhadas de fotomicrografios e desenhos esquemáticos e contagens d? número de estômatos c escamomas. A epiderme de todas as espécies apresenta a estrutura típica encontracia ro familia. O maior número de escamas foi encontrado no regiốo basal da folha em todas as espécies estudadas. Na maioria das espécies existe um relacionamento estrutural entre os estómatos e escamas, o que sugere um relacionamento funcional. A disp:siçâo, volume e aspecto dos tecidos variam de es. pécie para espécie e dentro de uma mesma folho. Todas as plantas apresentam caracteristicas estruturais que justificam sua presença na campina. 
Streptocalyx poeppigii Beer ................ 40

Epiderme superior em vista frontal ......... 40

Epiderme inferior em vista frontal .......... 40

Região meio-meio em corte transversal ....... 40

Região meio-margem em corte transversal ..... 42

Região ápice-meio em corte transversal ....... 45

Região base-meio em corte transversal ...... 45

Estômatos: vista frontai e corte transversal .... 45

Escamas: vista frontal e corte transversal ..... 47

Tillandsia adpressiflora Mez ................ 48

Epiderme superior em vista frontal .......... 48

Epiderme inferior em vista frontal .......... 48

Região meio-meio em corte transversal ....... 48

Região meio-margem em corte transversal ..... 50

Região ápice-meio em corte transversal ....... 50

Região base-meio em corte transversal ......... 53

Estômatos: vista frontal e corte transversal e longitudinal .......................... 57

Escamas: vista frontal e corte transversal ..... 58

Vriesea splitgerberi (Mez) L. B. Smith \& Pittendrigh 58

Epiderme superior em vista frontal .......... 58

Epiderme inferior em vista frontal ........... 58

Região meio-meio em corte transversal ....... 60

Região meio-margem em corte transversal ..... 62

Região ápice-meio em corte transversal ....... 62

Região base-meio em corte transversal ....... 62

Estômatos: vista frontal e corte transversal e lon-

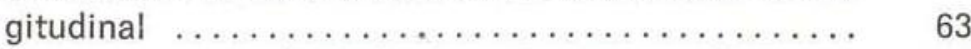

Escamas: vista frontal e corte transversal ..... 65

Discussão e Conclusões . . . . . . . . . . . . . . . . . 66

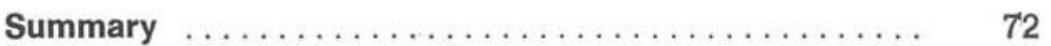

Bibliografia citada $\ldots \ldots \ldots \ldots \ldots \ldots \ldots \ldots \ldots \ldots \ldots \ldots$ 
CONTEÚDO

Introdução

Agradecimentos $\ldots \ldots \ldots \ldots \ldots \ldots \ldots \ldots \ldots \ldots$

Material e Método $\ldots \ldots \ldots \ldots \ldots \ldots \ldots \ldots \ldots \ldots$

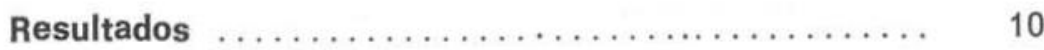

Aechmea mertensii (Meyer) Schult. ........... 10

Epiderme superior em vista frontal .......... 10

Epiderme inferior em vista frontal .......... 10

Região meio-meio em corte transversal ........ 13

Regiāo meio-margem em corte transversal ..... 15

Região ápice-meio em corte transversal ........ 18

Região base-meio em corte transversal ........ 18

Estômatos: vista frontal e corte transversal ...... 19

Escamas: vista frontal e corte transversal ...... 20

Aechmea setigera Mart. ex Schult. .......... 20

Epiderme superior em vista frontal ......... 20

Epiderme inferior em vista frontal .......... 22

Região meio-meio em corte transversal ........ 23

Região meio-margem em corte transversal ...... 26

Região ápice-meio em corte transversal ....... 27

Região base-meio em corte transversal ....... 27

Estômatos: vista frontal e corte transversal e lon-

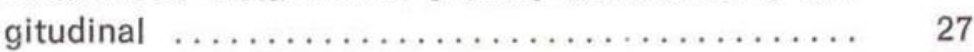

Escamas: vista frontal e corte transversal ...... 28

Ananas ananassoides (Baker) L. B. Smith ....... 30

Epiderme superior em vista frontal ......... 30

Epiderme inferior em vista frontal ........... 31

Região meio-meio em corte transversal ........ 32

Região meio-margem em corte transversal ...... 36

Região ápice-meio em corte transversal ....... 36

Região base-meio em corte transversal ........ 36

Estômatos: vista frontal e corte transversal e longitudinal ....................... 36

Escamas: vista frontal e corte transversal ..... 39 
A anatomia e fisiologia das Bromeliaceae são interessantes, entre outros aspectos, pelas adaptações ecológicas que estas apresentam. Estas adaptações consistem na progressiva redução estrutural e funcional das raízes e o concomitante desenvolvimento de parênquimas, estruturas de sustentação e principa!mente de escamas nas superfícies foliares.

Tomlinson (1969) cita variações estruturais entre escamas de uma mesma folha e entre as de folhas de espécies diferentes. Entretanto, não faz referências numéricas específicas sobre as diferenças que podem ocorrer nas diversas regiões da lâmina foliar. As variações estruturais que ocorrem são concernentes à forma, tamanho, número de células, espessamento das paredes, etc. Além disso, Tomlinson estuda a estrutura foliar e suas múltiplas adaptações.

Por toda a variabilidade adaptativa que apresentam as Bromeliaceae, a obtenção de dados anatômicos de escamas e estrutura foliar destas torna-se atraente e importante uma vez que possibilita especulações sob o ponto de vista filogenético, ontogenético, fisiológico, ecológico e taxonômico.

Em face dos motivos acima citados, pensou-se em realizar este trabalho, como uma contribuição para a aquisição de dados anatômicos referentes às escamas e estrutura foliar das Bromeliaceae em relação a um ambiente específico, de preferência bem delimitado. Isto permitiria fazer comparações entre as espécies em estudo e outras dos mesmos gêneros, cujas estruturas anatômicas já fossem conhecidas e verificar, caso ocorram, quais são as adaptações que estas espécies apresentam para um determinado tipo de ambiente.

Existindo na região um tipo vegetacional com características semelhantes às desejadas, foi fixada a área de trabalho. Trata-se de uma campina, ambiente relativamente delimitado, com aspectos edáficos e climáticos que Ihe dão características peculiares: a campina amazônica, tomada como referência para este estudo, é rala e baixa, muitas vezes com manchas arenosas expostas pela falta de cobertura vegetal. Por esta condição lembra "ilhas" dispersas no seio da floresta, contrastando com a exuberância desta, pela diferença de porte, estrutura e fisionomia (P. Lisbôa, 1975).

A campina é envolvida pela campinarana. que, segundo P. Lisbôa (1975), é uma vegetação mais desenvolvida do gradiente sucessional da campina, com árvores altas (até $20 \mathrm{~m}$ ), indivíduos sempre isolados e caracterizando-se pela presença de muitas epífitas em suas árvores.

O Instituto Nacional de Pesquisas da Amazônia possui, numa de suas reservas, uma área de campina típica - Reserva Biológica INPASUFRAMA - e nesta resolveu-se realizar 0 presente trabalho.

Nesta campina, a ocorrência de Bromeliaceae é muito representativa, inclusive na campinarana adjacente. As espécies ocorrentes são terrestres ou epífitas.

Para que melhor se possa situar nesta campina, foram anexados os dados climáticos seguintes:

Campina: umidade relativa média entre $81,0 \%$ e $90,0 \%$ temperatura do ar mínima absoluta de $17,7^{\circ} \mathrm{C}$, máxima absoluta de $38,0^{\circ} \mathrm{C}$ e temperatura média de $24,3^{\circ} \mathrm{C}$ e $27,3^{\circ} \mathrm{C}$;

Campinarana: umidade relativa média entre $91,0 \%$ e $97,0 \%$

temperatura do ar mínima absoluta de $19,0^{\circ} \mathrm{C}$, máxima absoluta de $33,0^{\circ} \mathrm{C}$ e temperatura média de $23,3^{\circ} \mathrm{C}$ e $26,0^{\circ} \mathrm{C}$ (Ribeiro \& Santos, 1975). 
R. Lisbôa (1975) fêz medições de luz sob e fora da copa de duas espécies arbóreas que tanto ocorrem na campina como campinarana e obteve:

Aldina heterophylla Spr. ex Benth.: $\bar{x}-3524,34$ lux sob a copa, 26895,38 lux fora da copa e $13,03 \%$ de luz filtrada;

Glycoxylon inophyllum (Mart. ex Miq.) Ducke: $\bar{x}-8220,89$ lux sob a copa, 24464,10 lux fora da copa e $33,67 \%$ de iuz filtrada.

Conhecendo-se os aspectos acima, que podem estar influenciando o desenvolvimento das Bromeliaceae na campina, foram relacionados os objetivos específicos deste trabaIho: - recolher dados que permitam melhor caracterização funcional das escamas, relacionando região da folha, número de estômatos e escamas por área, tipo de escamas e estômatos, número de células do pedículo e do escudo e aspectos gerais da epiderme. Pensa-se numa possível variação numérica de es- camas numa folha, que, junto com variações estruturais, possam sugerir áreas diferentes quanto à distribuição das mesmas, levando em conta as possíveis funções que possam realizar. Paralelamente, serão reunidos dados da estrutura da folha, que serão analisados com os anteriores, sob o ponto de vista do ambiente em que as espécies em questão foram encontradas e, finalmente, os resultados obtidos serão comparados com os dados conhecidos sob o ponto de vista anatômico, fisiológico e filogenético.

\section{AGRADECIMENTOS}

A Professora Dra. Berta Lange de Morretes, Dr. Ghillean T. Prance, Dr. Herbert Schubart e Dr. Arno Brune meus agradecimentos pela revisão parcial ou total deste trabalho. A todos que participaram de alguma forma para a realização deste - obrigado. 


\section{MATERIAL E MÉTODO}

A coleta do material em estudo foi feita nas campinas dos km 60 e 62 da BR-174, estrada Manaus-Caracaraí - Reserva Biológica INPA-SUFRAMA. A campina do km 62 ocorre na latitude $2^{\circ} 30^{\prime} 00^{\prime \prime} \mathrm{S}$, longitude $60^{\circ} 00^{\prime} 00^{\prime \prime}$. W a 44 metros de altitude (Ribeiro \& Santos, 1975).

As espécies em estudo neste trabalho, comuns nestas campinas, são:

Aechmea mertensii (Meyer) Schult.

Aechmea setigera Mart. ex Schult.

Ananas ananassoides (Baker) L. B. Smith

Streptocalyx poeppigii Beer

Tillandsia adpressiflora Mez

Vriesea splitgerberi (Mez) L. B. Smith \& Pittendrigh

O material-testemunho encontra-se no Herbário do Instituto Nacional de Pesquisas da Amazônia (INPA) e sua identificação foi feita pela especialista na família, Ruby Braga.

1 - Aechmea mertensii (Meyer) Schult. Col. M.M.N. Braga 82-A (INPA 50562) (Fig. 1) - é uma espécie amplamente dispersa na campina; ocorre tanto epífita como terrestre. no solo arenoso ou sobre cobertura vegetal, umbrófila ou heliófila. Suas folhas, ainda, que, às vezes, estreitas, têm a base alargada, formando um pequeno tanque de armazenamento de água.

2 - Aechmea setigera Mart. ex Schult. - Col. M.M.N. Braga 111 (INPA 63642) (Fig. 2) ocorre como epífita ou terrestre (casualmente), umbrófila. Suas folhas são espessas e têm a base muito alargada, o que permite armazenamento de grande quantidade de água. Os acúleos encontrados nas margens de suas folhas, geralmente, prendem folhas caídas de outras árvores.

3 - Ananas ananassoides (Baker) L. B. Smith - Col. M.M.N. Braga 112 (INPA 61941) (Fig.

3) - é uma espécie que ocorre nas imedia- ções entre campina e campinarana; terrestre, umbrófila. Tem folhas espessas, mas suas bases são relativamente estreitas, podendo armazenar pequena quantidade de água.

4 - Streptocalyx poeppigii Beer - Col. M.M.N. Braga 81-A (INPA 50561) (Fig. 4) ocorre tanto na campina como nas imediações desta com a campinarana; terrestre ou epífita, umbrófila ou heliófila. Forma com a base das folhas um tanque de armazenamento de considerável quantidade de água.

5 - Tillandsia adpressiflora Mez - Col. M.M.N. Braga 113 (INPA 63643) (Fig. 5) - é encontrada na campina e campinarana; terrestre ou epífita, umbrófila ou heliófila, armazena grande quantidade de água na base de suas folhas.

6 - Vriesea splitgerberi (Mez) L. B. Smith \& Pittendrigh - Col. M.M.N. Braga 105 (INPA 50563) (Fig. 6) - ocorre, principalmente, nos limites entre campina e campinarana; terrestre ou epífita, umbrófila, com a base das foIhas largas armazena grande quantidade de água.

As folhas usadas neste trabalho foram sempre aquelas localizadas na periferia da roseta por se tratarem de folhas adultas. Com o material foi realizado o seguinte:

a - DISSOCIAÇÃo DE EPIDERMES: para análise das epidermes foram tomadas cinco foIhas de cada espécie de uma mesma planta e de plantas diferentes. Cada folha foi dividida em seis regiões: base-meio, base-margem, meio-meio, meio-margem, ápice-meio e ápice-margem. De cada região citada foram cortados cinco quadrados de aproximadamente 1 $\mathrm{cm}$ de lado. Tal especificação foi feita para comparar o número e aspecto dos estômatos e escamas pertencentes a folhas da mesma espécie e regiões pertencentes a uma mesma foIha. 
As epidermes foram dissociadas pela mistura de Jeffrey (ácido crômico a 10\% e ácido nítrico a $10 \%$ em igual quantidade). Após a dissociação foram passadas na série água destilada, álcool $50 \%$, safranina, álcool $50 \%$, com inclusão em gelatina glicerinada.

A contagem do número de estômatos e escamas foi feita utilizando o aparelho Universal Projector UP-360 da Olympus Optical Co. Ltd. com aumento de $100 x$.

De cada quadrado acima referido foi feita a contagem do número de escamas da epiderme superior e das escamas e estômatos da epiderme inferior, incluídos no espaço de $1 \mathrm{~mm}^{2}$.

b - CORTES HISTOLÓgicos: o material para corte foi retirado de quatro regiões da foIha: base-meio, meio-meio, meio-margem e ápice-meio. Foram utilizados quatro diferentes fixadores: Dicromato de Potássio $(2 \%, 3 \%$, $4 \%$ e $5 \%$ aquoso), Lewitzki (ácido crômico $1 \%$ e formol $10 \%$ em partes iguais), FAA (álcool etílico a $50 \%$, ácido acético glacial e formol a $35 \%$ na proporção de 40:1:5 partes respectivamente) e Bouin (ácido acético glacial, for$\mathrm{mol} \mathrm{a} 40 \%$ e ácido pícrico aquoso saturado na proporção de 1:5:15 respectivamente).

Após a fixação foi feita a desidratação passando o material pela série alcoólica até parafina. Com permanência de um dia na estufa, o material foi incluído em parafina.
Os cortes foram feitos com 10 a $15 \mu \mathrm{m}$ de espessura num micrótomo rotativo Minot da Leitz, tipo 1212. Foram desparafinados e corados em vários corantes: Safranina-verde-luz (Sass, 1951), Hematoxilina de Heidenhain (Sass, 1951) modificada e Astrablau-Fucsina básica (conforme é usado por L. Krieger na Univ. Fed. de Juiz de Fora). Depois da coloração os cortes foram passados na série alcoólica e posteriormente montados em Bálsamo do Canadá.

C - RASPAGENS DAS SUPERFICIES FOLIARES: foram feitas raspagens com auxílio de uma lâmina de barbear para obtenção de escamas das seguintes regiōes: base-meio, base-margem, meio-meio, meio-margem, ápice-meio e ápice-margem. O material obtido foi montado com gelatina glicerinada.

d - CORTES À MÃo livre: de todas as espécies foram feitos cortes à mão livre de material fresco para uma análise comparada do mesmo e para realização de teste microquímico para amido (Sass, 1951).

Os desenhos esquemáticos foram feitos com uma câmara clara Leitz adaptada a um microscópio Reichert. As medidas foram tomadas com uma escala micrométrica Leitz. As fotomicrografias foram tiradas com um apareIho Nikon Apophot M. e com um fotomicroscópio da Zeiss equipado com ariel para contraste de fase. 

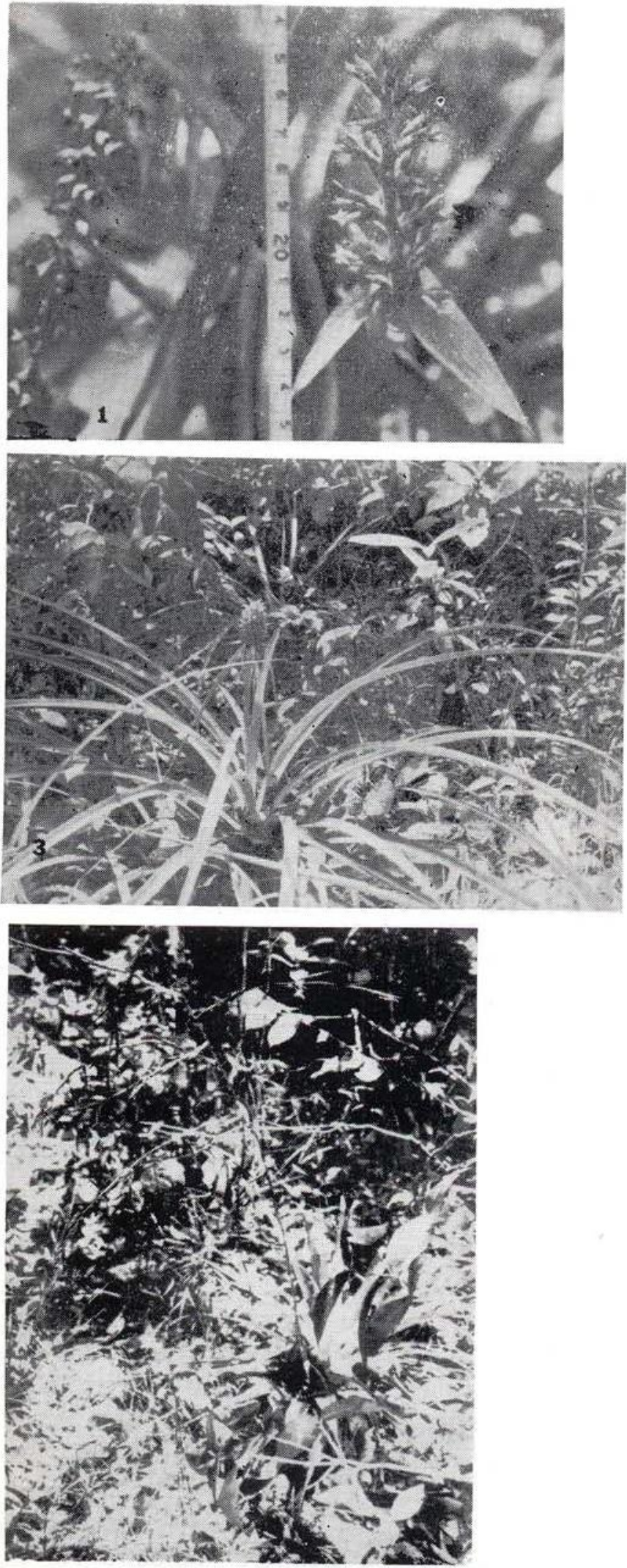
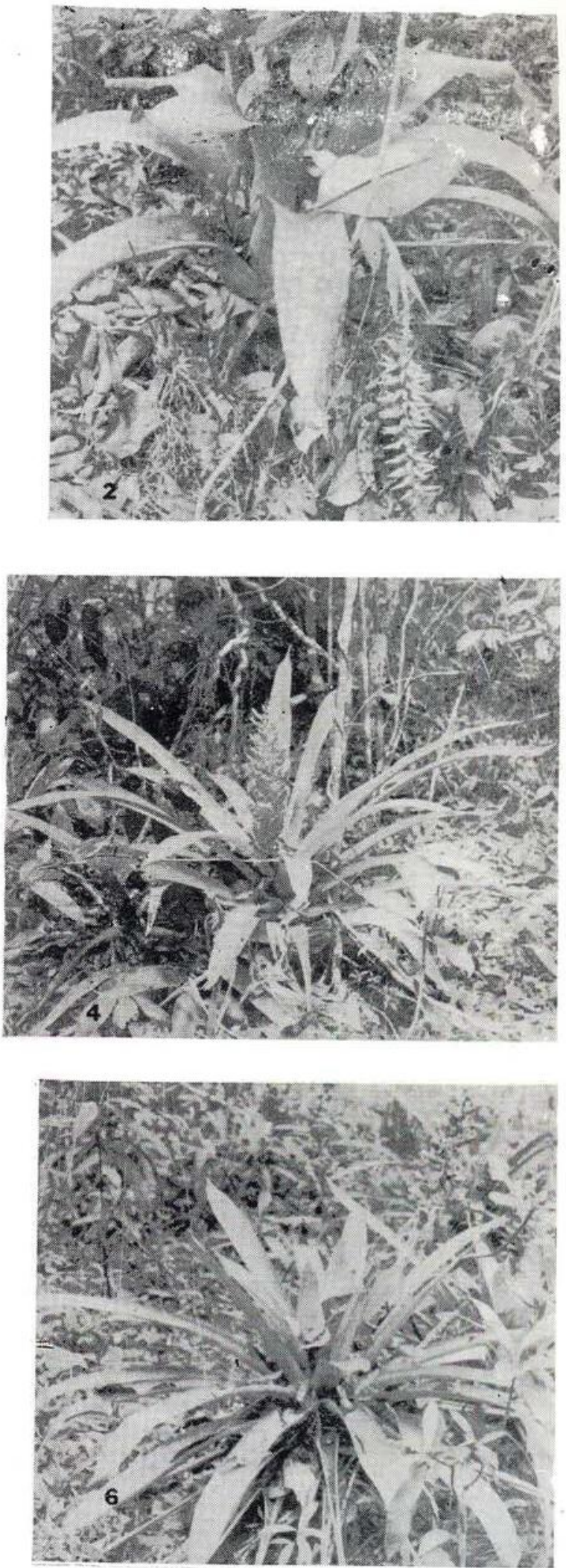

Fig. 1-6 - Aspecto das plantas na campina e imediaçôes com campinarana: 1. Aechmea mertensii, 2. Aechmea setigera, 3. Ananas ananassoides, 4. Streptocalyx poeppigii, 5. Tillandsia adpressiflora e 6. Vriesea splitgerberi. 


\section{RESULTADOS}

\section{Aechmea mertensii (Meyer) Schult.}

\section{EPIDERME SUPERIOR}

REGIÃO MEIO-MEIO:

A epiderme superior da folha de Aechmea mertensii é provida de escamas.

As células epidérmicas, em vista frontal, aparecem dispostas em fileiras' longitudinais com o eixo maior no mesmo sentido do comprimento da folha, apresentando forma quadrada, retangular ou irregular (Fig. 7 e 3); as células epidérmicas, localizadas entre duas escamas próximas, na mesma fila ('), têm geralmente a forma quadrada (Fig. 8). As paredes anticlinais das células são muito onduladas lembrando um quebra-cabeça (Fig. 7). No lume de cada uma, pode-se observar a presença de um pequeno corpo silicoso (Fig. 7).

As escamas encontram-se dispostas em filas irregulares: o espaço entre duas filas vizinhas é variável, bem como o espaço entre duas escamas próximas, na mesma fila. A média do número de escamas, que ocorre nesta região, é de 9,04 escamas por milímetro quadrado.

OUTRAS REGIÕES:

Nas demais regiões observadas: meio-margem, ápice-meio, ápice-margem, base-meio e base-margem, o aspecto da epiderme é semelhante a meio-meio, variando o número de escamas: na margem de cada região, o número de escamas foi menor que no meio da região correspondente; base-meio e ápice-meio apresentaram maior número de escamas que meio-meio (Fig. 9 e 10, Gráfico 1). Na base-margem as células apresentaram o menor tamanho e forma muito irregular (Fig. 11).
Na região onde emerge um acúleo, geralmente, há alteração na forma (irregulares), tamanho (pequenas) e disposição (confluindo para o acúleo) das células.

\section{EPIDERME INFERIOR}

REGIÃO MEIO-MEIO:

A epiderme inferior da folha de Aechmea mertensii é provida de escamas e estômatos.

As células epidérmicas têm características semelhantes às das células da epiderme superior, no que se refere à disposição, tamanho, forma, parede e conteúdo.

As escamas distribuem-se em filas irregulares como na epiderme superior (Fig. 12), em média de 6,84 escamas por mílimetro quadrado.

Os estômatos encontram-se nos espaços entre escamas consecutivas de uma mesma fila, às vezes em grupos de dois, três ou isolados (Fig. 12). Ocorrem sempre a uma certa distância das escamas, geralmente não estão cobertos pelo escudo das mesmas (Fig. 13). A média do número de estômatos, nesta região, é de 31,96 estômatos por milímetro quadrado.

OUTRAS REGIÕES:

As células epidérmicas da base-meio e base-margem apresentam diferenças das do meio-meio, no que se refere ao tamanho - geralmente são menores, as da base-margem caracterizam-se ainda pela forma que é irregular (Fig. 14).

As escamas apresentam variação numérica de região para região, conseqüentemente variando a distância entre uma e outra (Fig 12, 15 e 16, Gráfico 1).

(1) - Neste trabalho, refere-se à fila como uma disposição de apenas um elemento atrás do outro $=$ "fila indiana". 

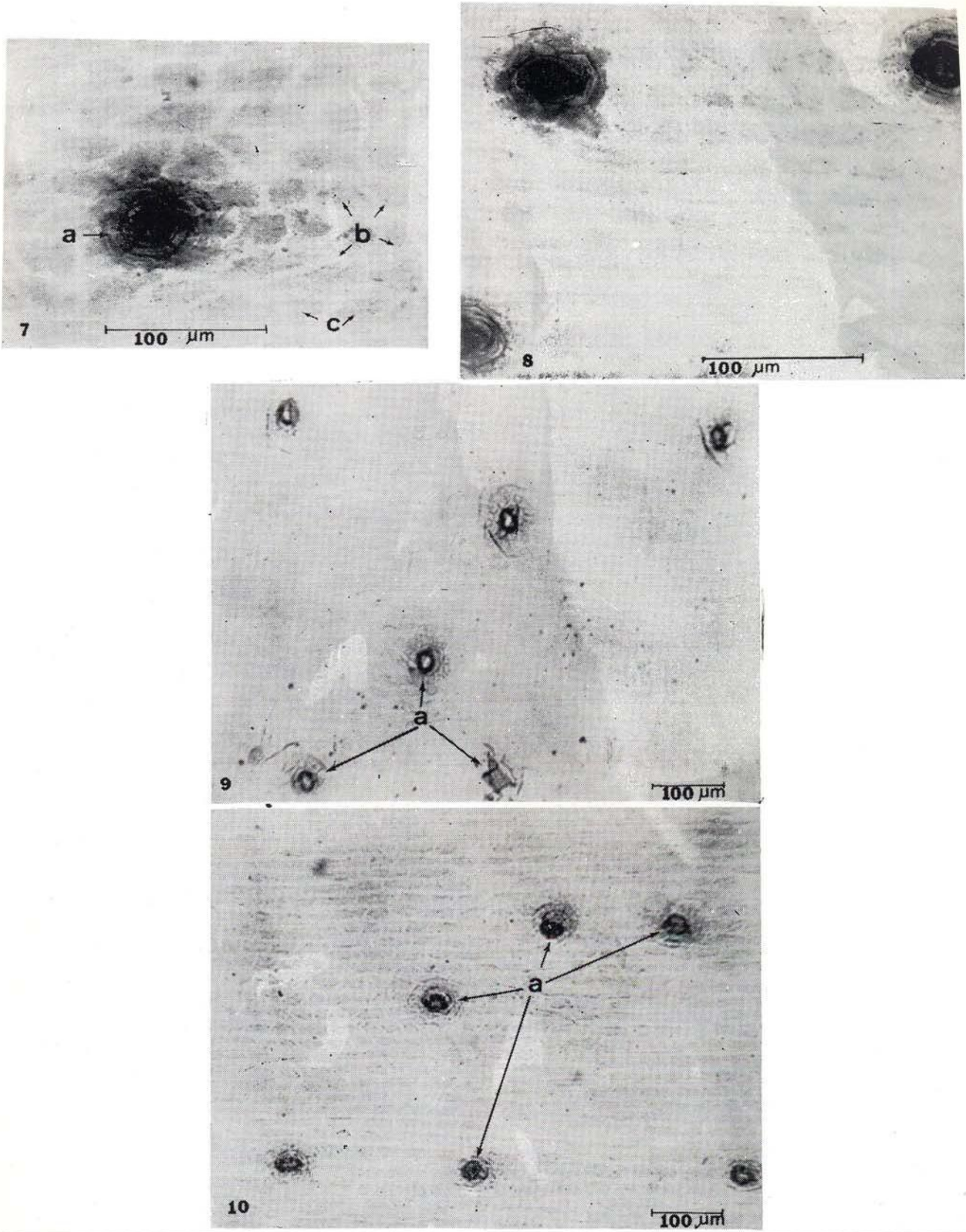

Fig. 7-10 - Aechmea mertensii. Epiderme superior em vista frontal; Fig. 7 - Meio-meio. a - escama, b células epidérmicas e c - corpos silicosos; Fig. 8 - Ápice-meio. Variação no tamanho das células epidérmicas entre duas escamas de uma mesma fila e entre escamas de filas diferentes; Fig. 9- Base-meio. a - escamas; Fig. 10 - Ápice-meio. a - escamas. 

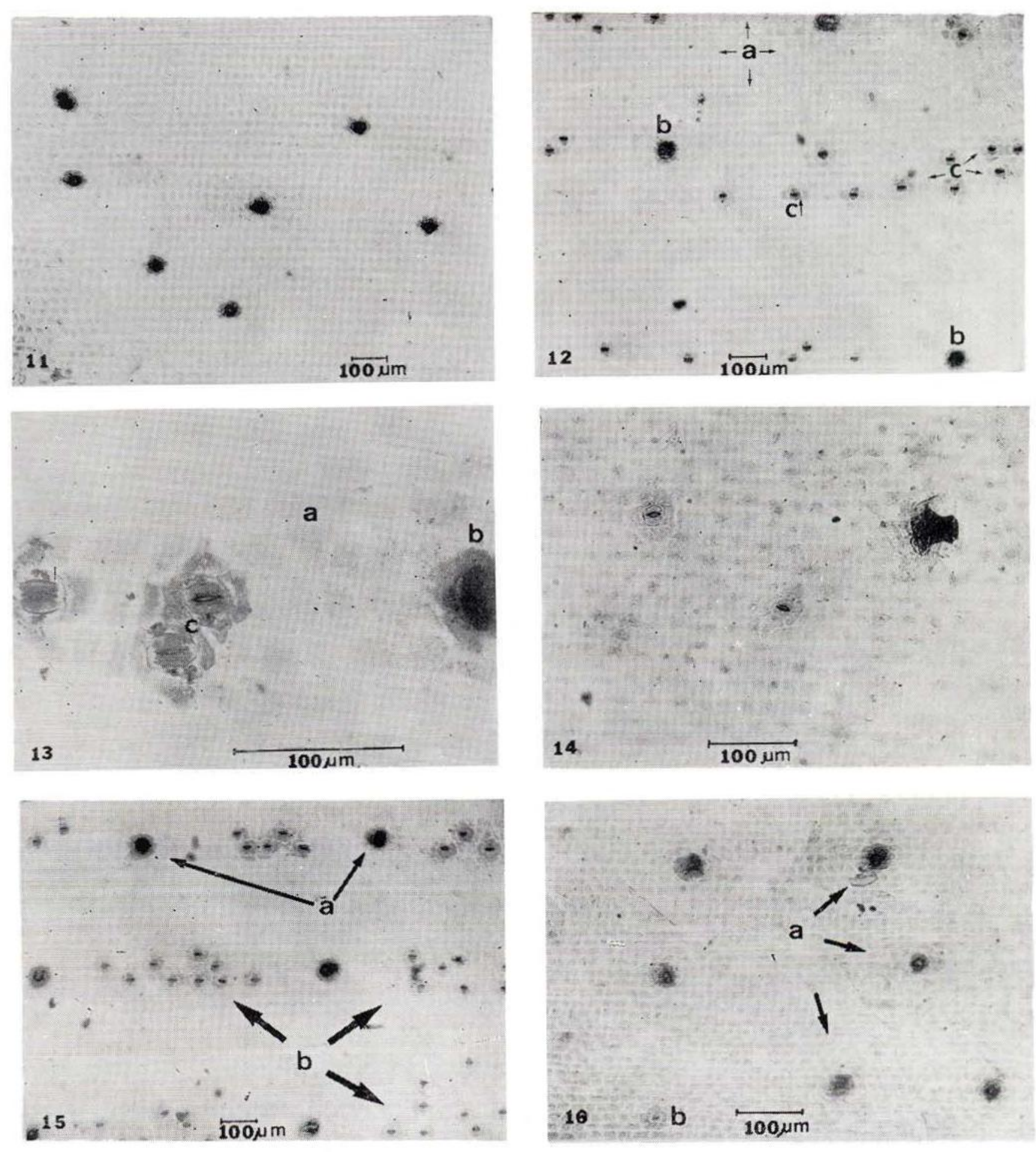

Fig. 11-16 - Aechmea mertensii: Fig. 11 - Epiderme superior em vista frontal. Base-margem. Variação do tamanho e forma das células comparados com de outras regiōes; Fig. 12 - Epiderme inferior. Meio-meio. a - células epidérmicas, b - escamas e c - estômatos; Fig. 13 - Epiderme inferior. Meio-meio. a - células epidérmicas, b - escama e c - estômatos; Fig. 14 - Epiderme inferior. Base-margem. Variação no tamanho e forma das células epidérmicas em comparação com as células do meio e ápice; Fig. 15 - Epiderme inferior. Ápice-margem. Variação do número de escamas e estômatos. a - escamas e b - estômatos; Fig. 16 - Epiderme inferior. Base-meio. Variação do número de escamas e estòmatos. a - escamas e b estômato. 
Os estômatos da região meio-margem se dispõem como na região meio-meio; no ápice-meio e ápice-margem estão mais agrupados que em meio-meio; na base-meio e base-margem deviáo ao pequeno número de ocorrência destes, encontram-se isolados (Fig. 15 e 16, Gráfico 1). O número de estômatos decresce do ápice para a base (Gráfico 1). Os estômatos não apresentam relacionamento estrutural com as escamas (Fig. 16 e 17).

\section{REGIÃo MEIO-MEIO DA FOLHA EM CORTE} TRANSVERSAL (Fig. 18)

A epiderme superior da folha de Aechmea mertensii, em corte transversal, mostra-se constituída de uma camada de células pequenas, pentagonais, cujas paredes anticlinais e periclinal interna possuem um espessamento, sendo a parede periclinal externa muito delgada. O lume de cada célula é reduzido, tem geralmente forma de uma lente biconvexa e é portador de um pequeno corpo silicoso esférico.

As células da epiderme dispõem-se normalmente, lado a lado, em linha reta, no entanto, aquelas que envolvem o pedículo de uma escama ocupam um nivel inferior às demais.

Logo abaixo da epiderme observa-se a hipoderme uniforme, com células arredondadas, pouco maiores que as células epidérmicas, de paredes delgadas e sem conteúdo aparente, às vezes o espessamento das células

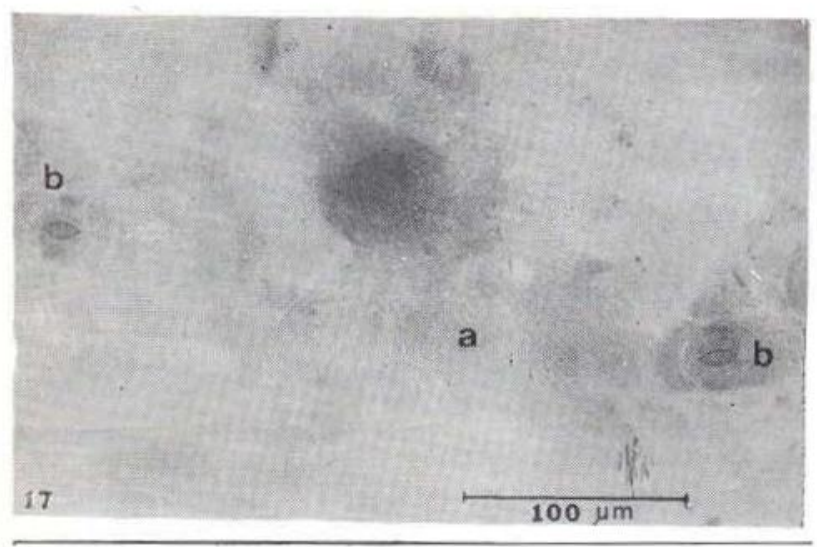

Fig. 17 - Aechmea mertensii. Epiderme inferior em vista frontal. Ápice-margem. O escudo da escama ñão cobre os estômatos. a - escudo da escama e b - estômatos.

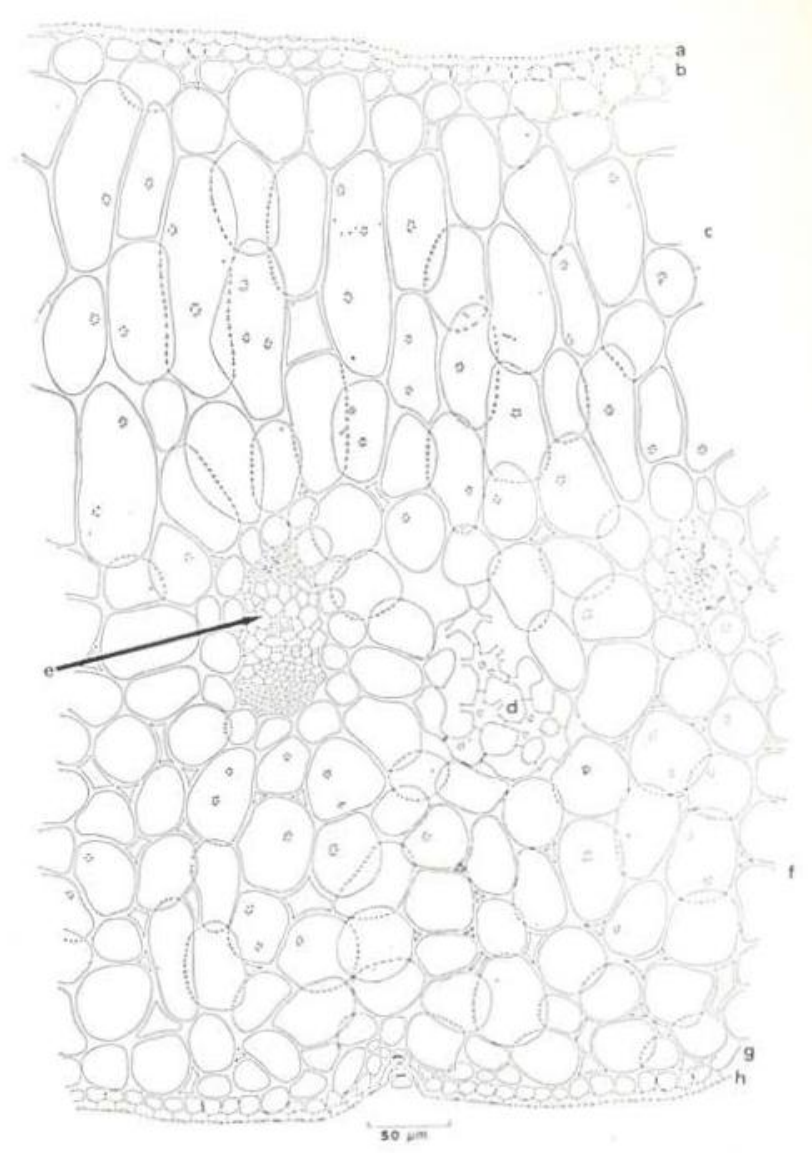

Fig. 18 - Aechmea mertensii. Corte transversal da região meio-meio. Aspecto geral: a - epiderme superior; b - hipoderme superior; $\mathrm{c}-$ parênquima aqüífero; d - parênquima braciforme; e - feixe vascular; $f$ - parênquima clorofiliano; $g$ - hipoderme inferior; $\mathrm{h}$ - epiderme inferior.

epidérmicas "prolonga-se" nas paredes anticlinais dessas células. Em seguida encontrase o parênquima aqüífero constituído de várias camadas de células (quatro a cinco), que é responsável por metade da espessura da foIha. O parênquima aqüífero possui células grandes, hexagonais, arredondadas ou irregulares, de paredes delgadas e, algumas vezes, contendo uns poucos cloroplastos (Fig. 19).

A metade inferior da folha é constituída, principalmente, pelo parênquima clorofiliano. Este apresenta-se sob duas formas: parênquima clorofiliano propriamente dito e parênquima braciforme, aos quais se pode acrescentar, também, o parênquima aqüífero. Na figura 20 , verifica-se a distribuição de cloroplastos nestes tecidos. 

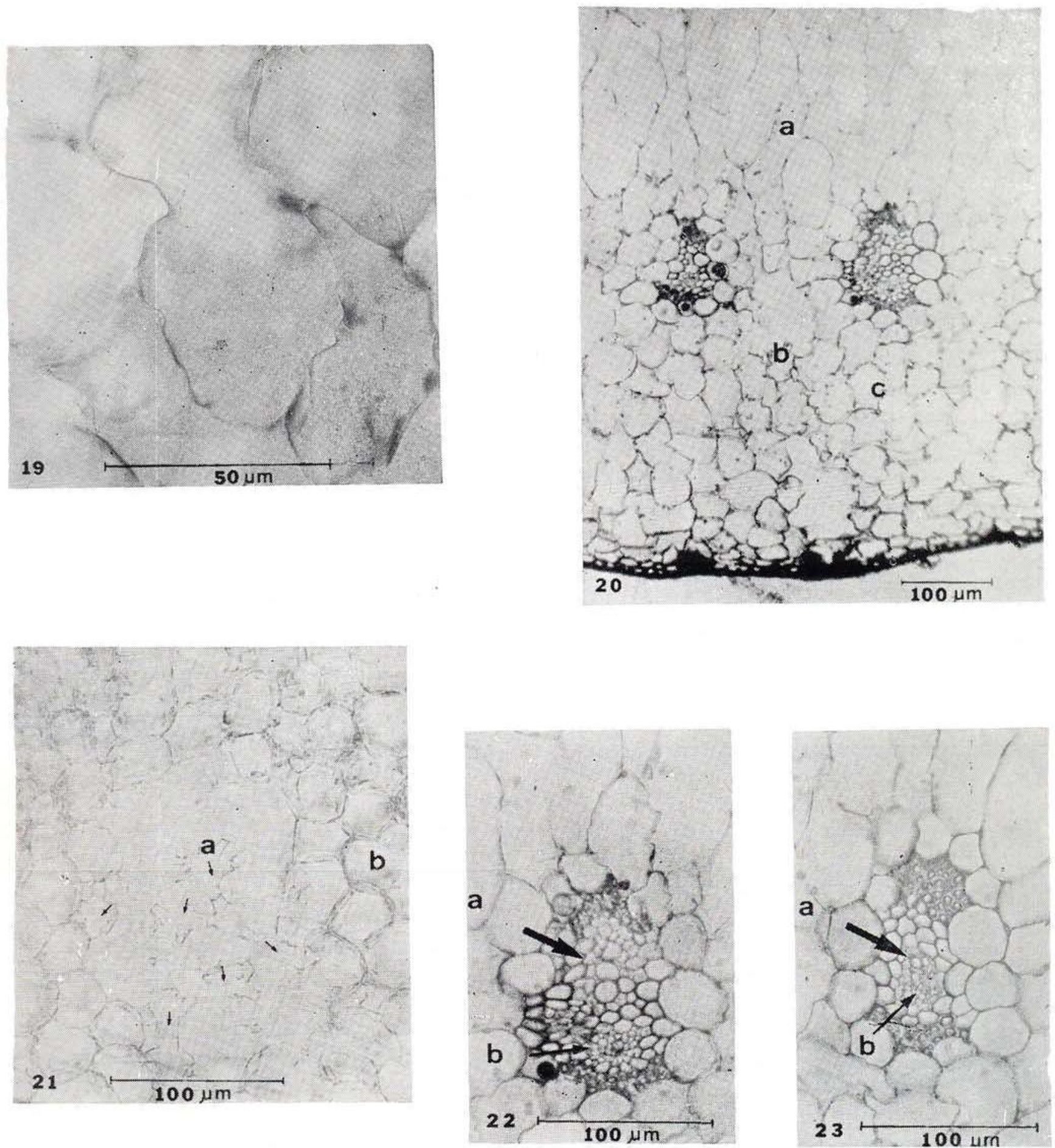

F'ig. 19-23 - Aechmea mertensii: Fig. 19 - Corte transversal da região meio-meio. Células do parênquima aqüífero; Fig. 20 - Corte transversal da região meio-meio. Distribuição de cloroplastos, a - no parênquima aqüífero, $\mathrm{b}-$ no parênquima braciforme e $\mathrm{c}-$ no parênquima clorofiliano; Fig. 21 - Corte transversal da região meio-meio. Células do parênquima braciforme entre células do parênquima clorofiliano, a - células do parênquima braciforme e b - células do parênquima clorofiliano; Fig. 22 - Corte transversal da região meio-meio. Feixe vascular principal. a - xilema e b-floema; Fig. 23 - Corte transversal da região meio-meio. Feixe vascular secundário. a - xilema e b - floema. 
O parênquima clorofiliano propriamente dito é constituído de várias camadas de células arredondadas, grandes, de paredes finas, poucos cloroplastos (principalmente nas camadas inferiores) (Fig. 20).

O parênquima braciforme encontra-se entre os feixes vasculares, situando-se em nível ligeiramente inferior aos mesmos. Suas células apresentam cerca de cinco a seis braços, paredes finas e poucos cloroplastos, não formam um "canal" distinto de células até os estômatos. O espaço entre os feixes ocupado por este parênquima é relativamente pequeno, o que sugere que a quantidade de ar armazenada neste é pequena (Fig. 21).

Os feixes vasculares dispõem-se para!elamente uns aos outros, separados em parte pelo parênquima braciforme e por células do parênquima clorofiliano propriamente dito que circundam o parênquima braciforme. Encontram-se, lado a lado, feixes mais desenvolvidos (feixes principais) e feixes menos desenvolvidos (feixes secundários). De um modo geral os feixes apresentam em suas extremidades superior e inferior grupos de fibras esclerenquimáticas. O metaxilema possui cerca de dois vasos grandes envolvidos por células parenquimáticas (Fig. 22). As células localizadas lateral e externamente no feixe apresentam paredes um pouco espessadas. Feixes vasculares menos desenvolvidos apresentam menor número de vasos (Fig. 23). Verificamse, freqüentemente, feixes atravessando o parênquima braciforme, que permitem uma comunicação entre os feixes paralelos, que percorrem a folha em sentido longitudinal (Fig. 24 e 25).

Abaixo do parênquima clorofiliano ocorre uma hipoderme semelhante quanto ao aspecto à hipoderme superior.

A epiderme inferior difere da epiderme superior por apresentar estômatos.

\section{REGIÃo MEIO-MARGEM DA FOLHA EM CORTE TRANSVERSAL (Fig. 26)}

Um corte da região meio-margem difere de um corte da região meio-meio, nos seguintes aspectos:
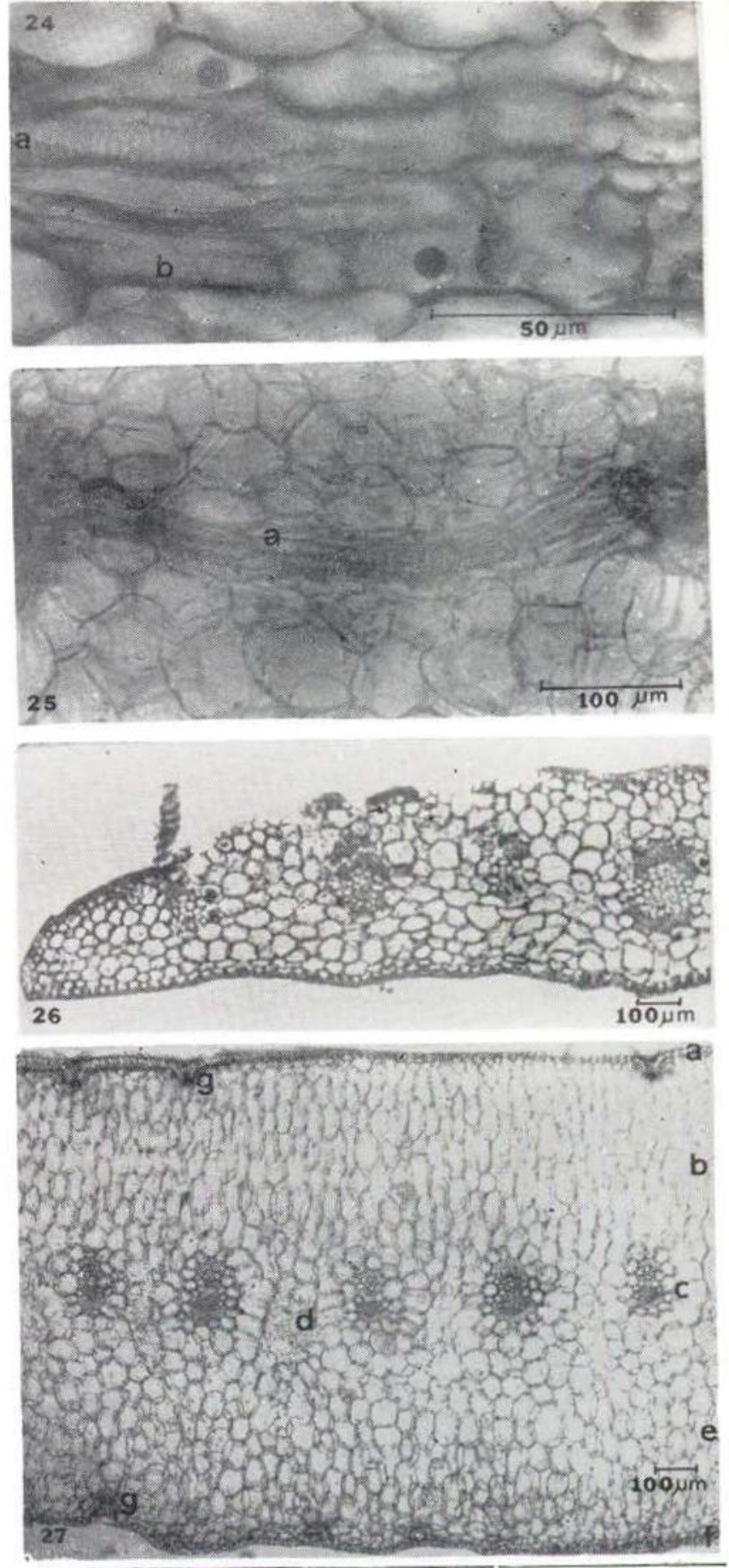

Fig. 24-27 - Aechmea mertensii. Fig. 24 - Corte transversal da região meio-meio. Feixe atravessando o parênquima braciforme. a - elemento de vaso com espessamento escalariforme e b - elemento de vaso com espessamento pontuado. Fig. $25-$ Corte transversal da região meio-meio. a - ramificação lateral ligando dois feixes vasculares. Fig. 26 - Corte transversal da região meio-margem da folha. Aspecto geral. Fig. 27 - Corte transversal da região ápice-meio da folha. Aspecto geral. a - epiderme e hipoderme, $\mathrm{b}$ - parênquima aquífero, c feixe vascular, d - parênquima braciforme, e parênquima clorofiliano, $\mathrm{f}$ - epiderme e hipoderme inferiores e g - escamas. 

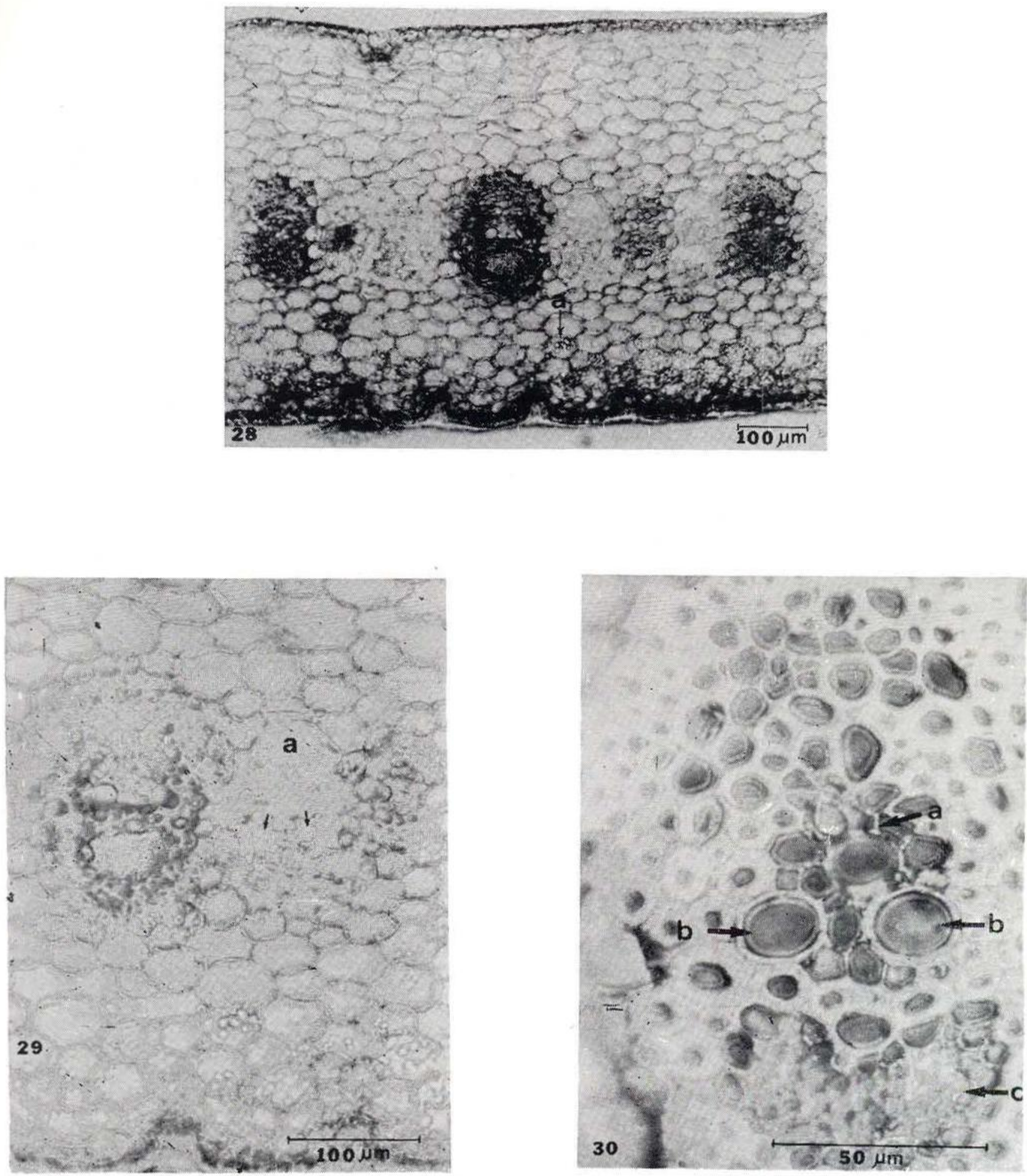

Fig. 28-30 - Aechmea mertensii. Fig. 28 - Corte transversal da região base-meio. Aspecto geral. a - grãos de amido. Fig. 29 - Corte transversal da região base-meio. Parênquima braciforme diretamente ligado ao feixe vasculan a - células do parênquima braciforme. Fig. 30 - Corte transversal da região base-meio. Feixe vascular. a - vestígios de elementos de vasos do protoxilema, b - elementos de vasos do metaxilema e c - floema. 

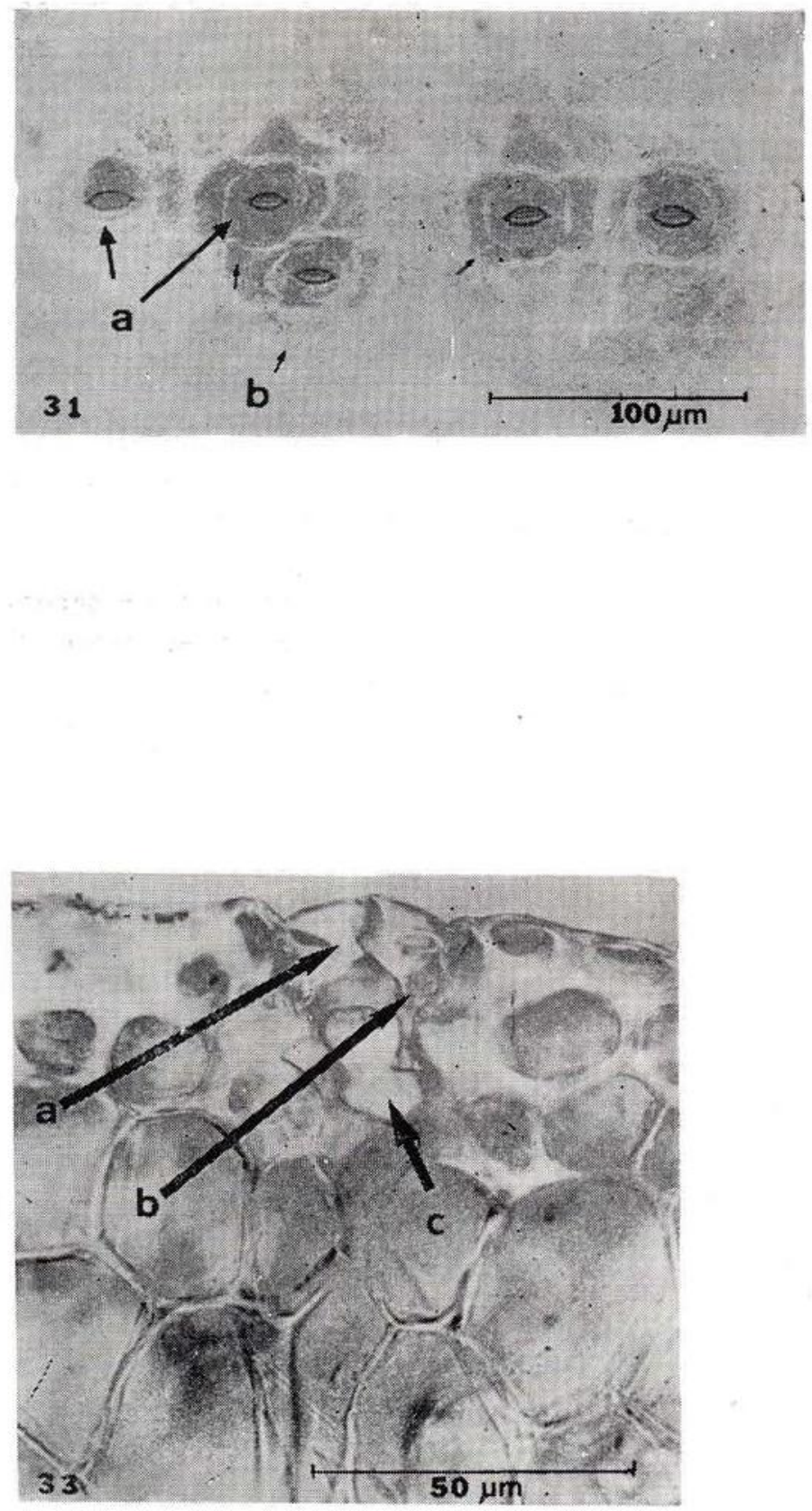
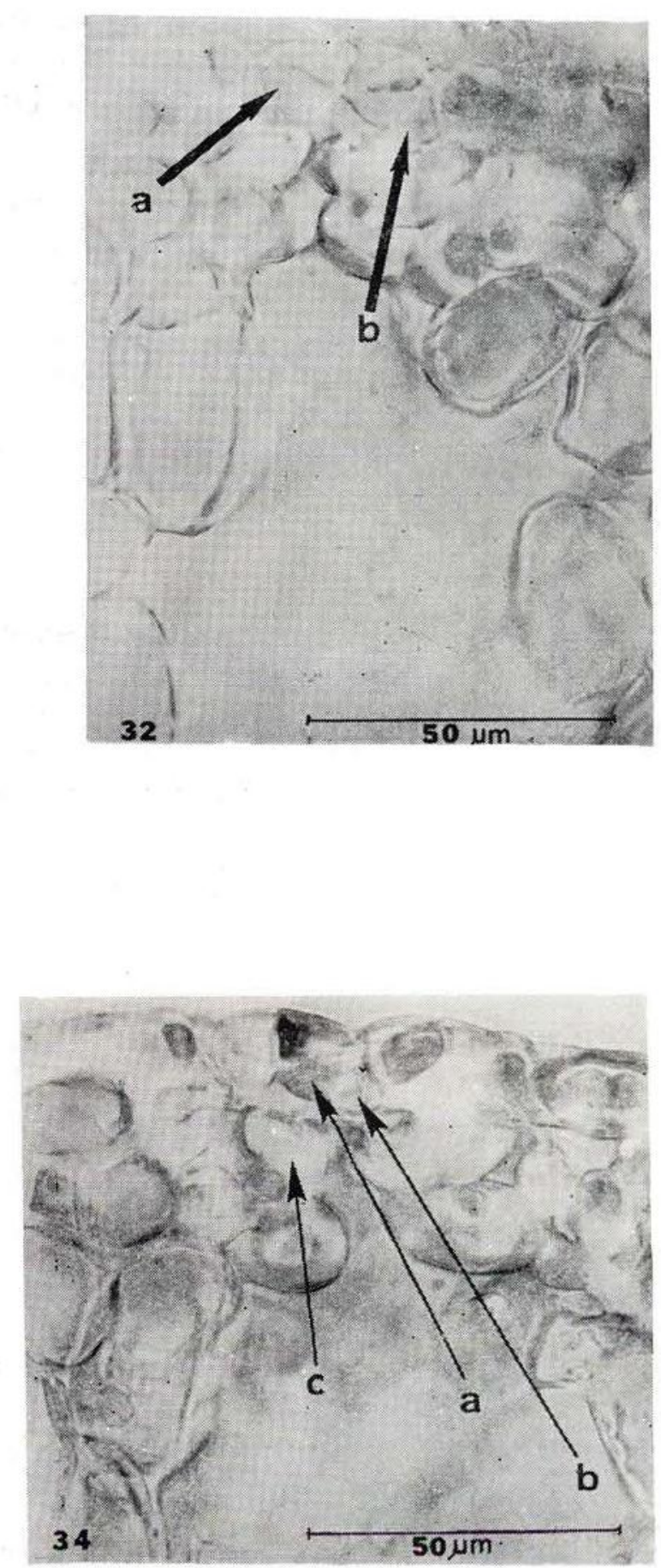

rig. 31-34 - Aechmea mertensii. Epiaerme inierior em vista frontal. Fig. 31 - Vista frontal. Ápice-margem. a - células guardas dos estômatos e b - células vizinhas dos estômatos. Fig. 32 - Corte transversal da região meio-meio. a - célula-guarda do estômato em corte transversal na região mediana e b - célula subsidiária. Fig. 33 - Corte transversal da região meio-meio. a - célula-guarda do estômato em corte transversal na região mediana, b - célula subsidiária e c - projeções esclerificadas, obstruindo a entrada da câmara subestomática. Fig. 34 - Corte transversal da região meio-meio. a - célula-guarda do estômato em corte transversal na região polar, b-célula subsidiária e c - projeções esclerificadas, obstruindo a entrada da câmara subestomática. 
- as células do parênquima aqüífero não apresentam sua forma característica - hexa. gonais alongadas, tendendo à forma esférica;

- o parênquima braciforme não ocorre, sendo o espaço deste ocupado por células do parênquima clorofiliano; e

- os feixes vasculares que ocorrem na periferia são feixes menos desenvolvidos feixes secundários.

\section{REGIÃO ÁPICE-MEIO DA FOLHA EM CORTE} TRANSVERSAL (Fig. 27)

Esta região apresenta a mesma distribuição estrutural que meio-meio; diferencia-se desta pelo fato de as células, tanto do parênquima clorofiliano como aqüífero, serem pequenas, o que resulta num maior número de camadas de células, uma vez que quase não há diferença de espessura da folha de uma região para outra; além disto, os feixes vasculares apresentam o revestimento de fibras esclerenquimáticas das extremidades mais desenvolvido.

\section{REGIÃo BASE-MEIO DA FOLHA EM CORTE} TRANSVERSAL (Fig. 28)

Esta região apresenta muitas diferenças em relação à região meio-meio:

- as células do parênquima aqüífero possuem forma e tamanho semelhante aos das células do parênquima clorofiliano;

- o parênquima braciforme é mais desenvolvido, estando suas células diretamente ligadas ao feixe vascular (Fig. 29);

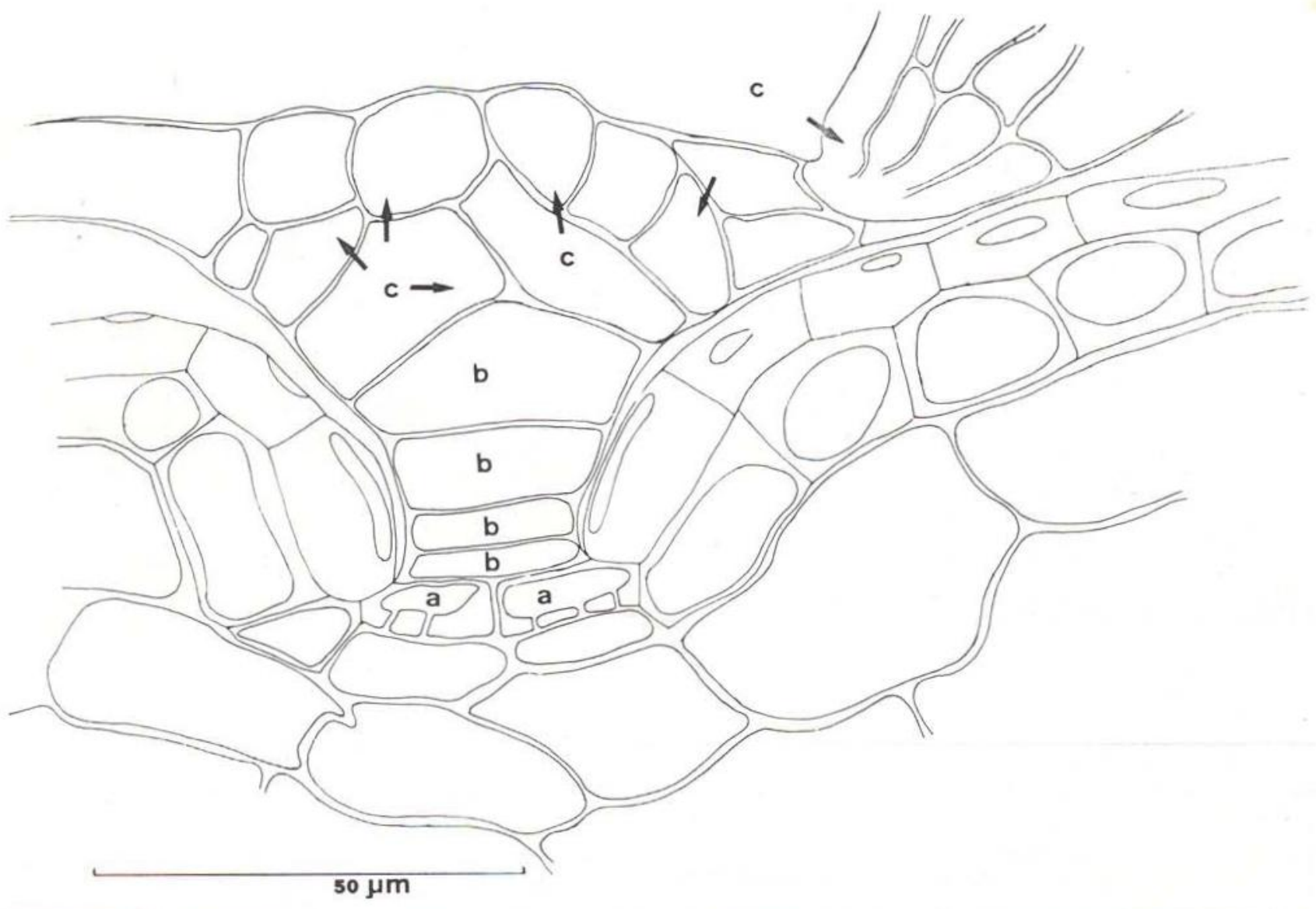

Fig. 37 - Aechmea mertensii - Corte transversal de uma escama. Base-meio. Epiderme superior. a - células basais, b - células do pedículo e c - células do escudo. 
- nos feixes vasculares observa-se um nítido espessamento das células que envolvem o xilema e o floema (Fig. 30);

- as células correspondentes àquelas dos parênquimas clorofiliano e braciforme não possuem cloroplastos e estão repletas de grãos de amido, estes podem ocorrer em menor quantidade, no parênquima açüífero (Fig. 29). Os grãos de amido apresentam-se isolados, geminados ou trigeminados.

\section{EsTômatos: vista frontal e corte transversal}

Os estômatos, em vista frontal da face externa da epiderme, aparecem envolvidos por cerca de quatro a sete células vizinhas. Estas células diferenciam-se das demais células ep:dérmicas por não apresentarem corpo silicoso e por terem as paredes, ou pelo menos a parede voltada para o estômato, retilíneas, sem as características ondulações das paredes das demais células epidérmicas (Fig. 31). Destas células vizinhas, duas se dispõem nos polos do estômato (uma em cada), duas a quatro se dispõem lateralmente nos polos.

Quando os estômatos estão agrupados, geralmente a célula vizinha de um estômato o é também de outro, isto é, dois estômatos têm uma ou mais células vizinhas em comum.

As figuras 32 e 33 mostram cortes transversais da região mediana das células-guardas dos estômatos. Pode-se observar que as células subsidiárias encontram-se latero-inferiormente em relação às células-guardas, quase não atingem o nível da parede periclinal externa das células epidérmicas, o que dificulta a observação daquelas em vista fronta! da face externa da epiderme.

O lume das células-guardas parece uma lente biconvexa, o mesmo não se observa em relação a este na região polar das mesmas, onde tem a forma de um triângulı isósceles em posição horizontal (Fig. 34).
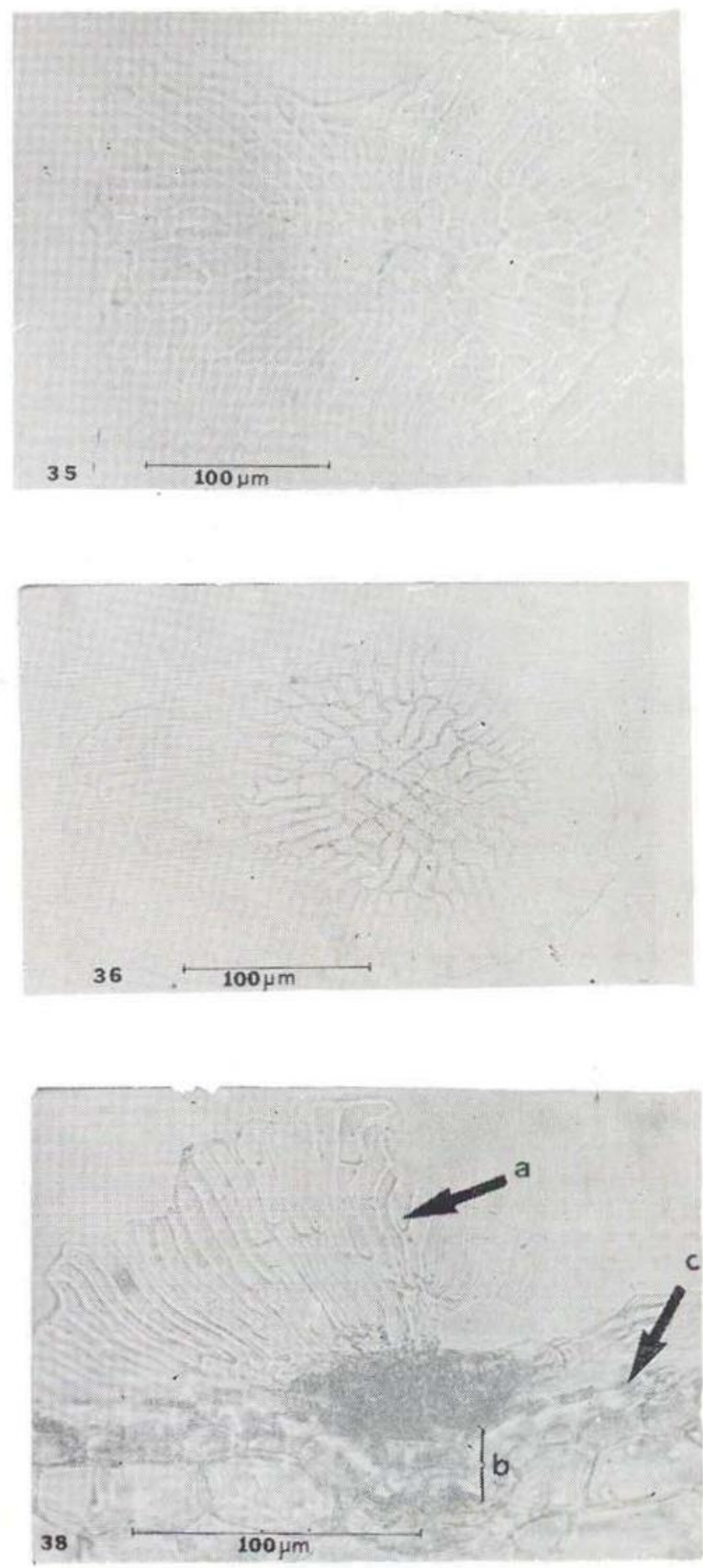

Fig. 35, 36 e 38 - Aechmea mertensii. Escamas. Fig. 35 - Escama da epiderme superior em vista frontal. Meio-meio. Escudo com camadas de células concêntricas desorganizadas. Fig. 36 - Escama da epiderme inferior em vista frontal. Base-meio. Escudo com camadas de células concêntricas organizadas. Fig. 38 - Corte transversal de uma escama. Base-meio. Epiderme superior, a - escudo, b pedículo e c - célula epidérmica 
Ainda, nestas figuras 32,33 e 34 , verifica-se a presença de células de paredes espessas, cujo lume geralmente desaparece, e que obstruem a entrada da câmara subestomática.

ESCAMAS: vista frontal e corte transversal

As escamas em vista frontal, apresentam-se, às vezes, com a forma arredondada, ora regular, ora irregular. A partir do centro do escudo, possuem três ou quatro, camadas de células, sendo que em cada camada pode ocorrer uma nova divisão em algumas células, dando um aspecto desorganizado à estrutura do escudo (Fig. 35); às vezes, o desenvolvimento das células de cada camada, mesmo com as referidas divisões, é semelhante, o que permite visualizar a nítida formação das camadas (Fig. 36).

Em corte transversal, estas escamas mostram ser constituídas de: duas células basais, quatro células do pedículo e células do escudo. As células basais possuem paredes espessas com grandes pontuações, o que também pode ser observado nas células adjacentes inferiores (Fig. 37 e 38).

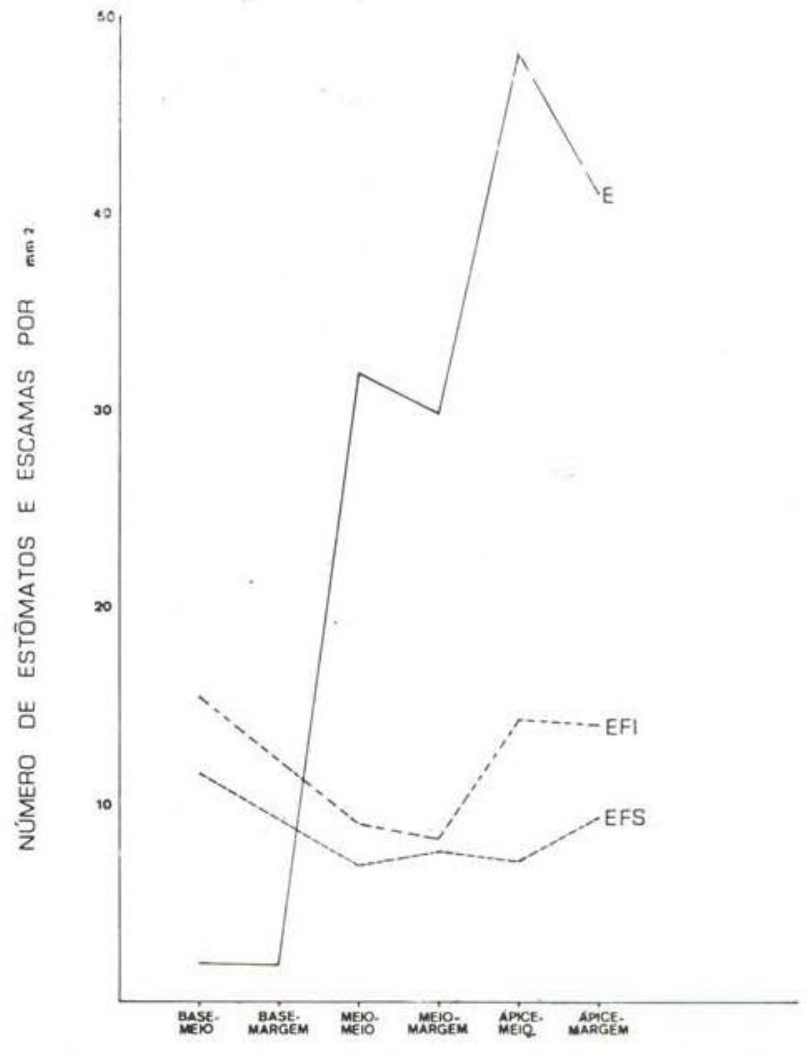

Gráfico 1 - Aechmea mertensii. E - média do número de estômatos, EFS - média do número de escamas da face superior e EFI - média do número de escamas da face inferior.

Aechmea setigera Mart. ex Schult.

\section{EPIDERME SUPERIOR}

REGIÃO MEIO-MEIO:

A epiderme superior da folha de Aechmea setigera é provida de escamas.

As células epidérmicas, em vista frontal, aparecem dispostas em fileiras longitudinais, estando o eixo maior das células no mesmo sentido do comprimento da folha; possuem forma quadrada, retangular ou retangular alongada, mas principalmente a forma retangular (Fig. 39). As células localizadas entre duas filas próximas têm geralmente a forma alongada, enquanto as que se encontram entre duas escamas vízinhas, na mesma fila, apresentam, geralmente, a forma quadrada. As paredes an- ticlinais das células são muito onduladas, lembrando um quebra-cabeça. No lume das células, podemos observar a presença de um pequeno corpo silicoso.

As escamas se dispõem em filas muito irregulares, variando o espaço entre duas filas vizinhas e o espaço entre duas escamas consecutivas, na mesma fila. A média do número de escamas é de 9,2 por milímetro quadrado.

OUTRAS REGIÕES:

Nas regiões meio-margem, ápice-meio e ápice-margem, o aspecto da epiderme é semeIhante a meio-meio, variando, como para as outras regiões, o número de escamas (Fig. 40 e 41, Gráfico 2). 

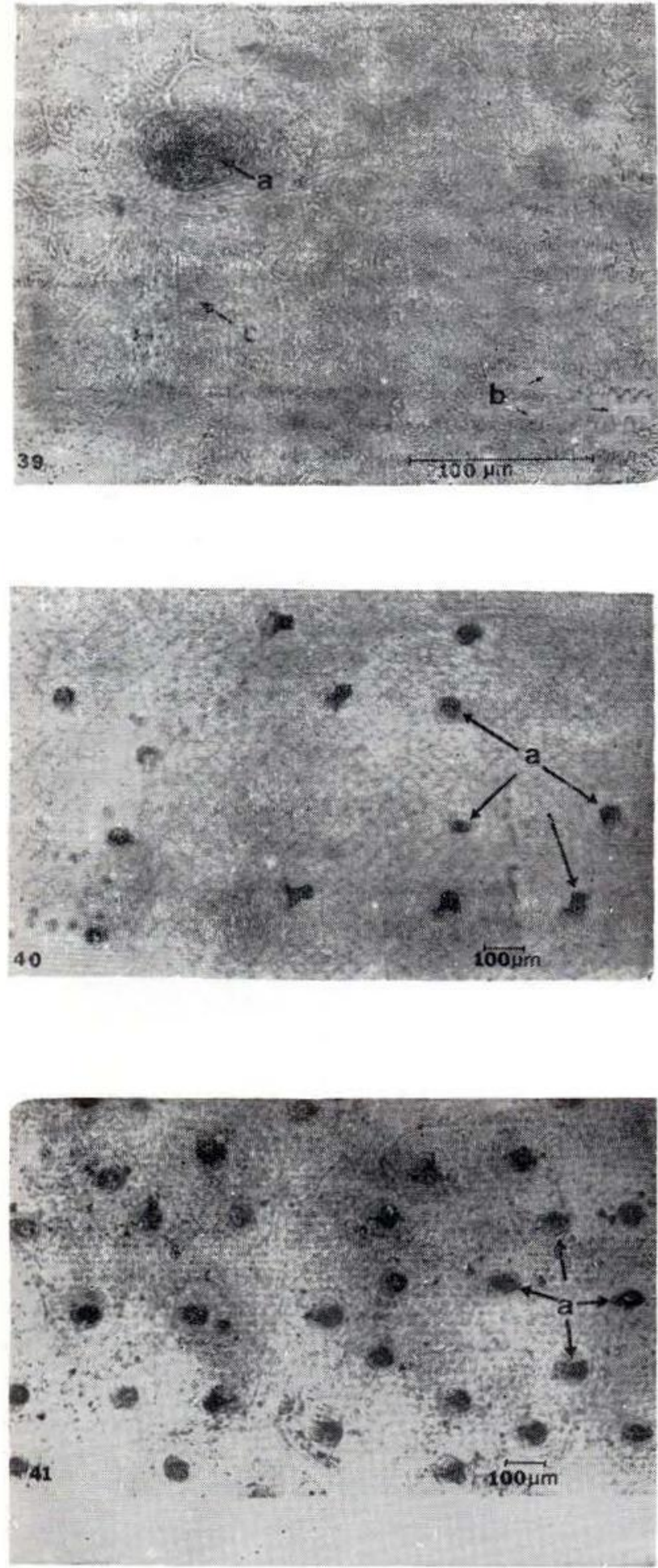

Fig. 39-41 - Aechmea setigera. Epiderme superior em vista frontal. Fig. 39 - Meio-meio. a - centro da escama, b - células epidérmicas e c - células do escudo. Fig. 40 - Ápice-meio. Variação do número de escamas. a - escamas. Fig. 41 - Base-meio. Variação do número de escamas. a - escamas.
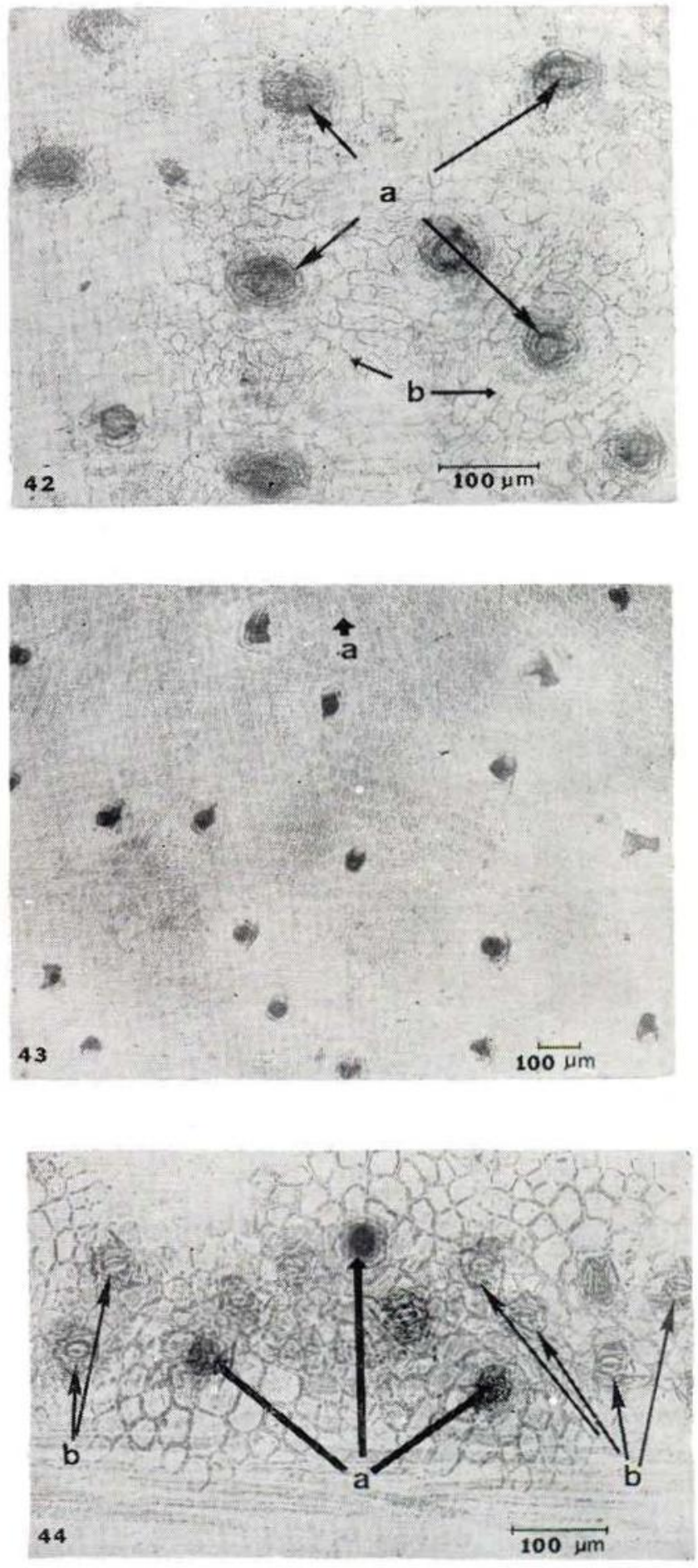

Fig. 42-44 - Aechmea setigera. Fig. 42 - Epiderme superior em viste frontal. Base-meio. Escudos das escamas cobrem completamente a superfície foliar. a - centro da escama e b - células do escudo. Fig. 43 - Epiderme superior em vista frontal. Meio-margem. a - região onde sai um acúleo. Fig. 44 - Epiderme inferior em vista frontal. Meio-meio. Faixa de escamas, estômatos e células epidérmicas. $\mathrm{a}$ - centro das escamas e b - estômatos. 
A região que apresenta o maior número de escamas é a região basal, esta tem o dobro do número de escamas do ápice e o triplo do número de escamas do meio (Gráfico 2).

$\mathrm{Na}$ base-meio e base-margem, além da variação do número de escamas, verificam-se também diferenças, em relação às demais regiões, no que concerne ao tamanho das células, que, agora são pequenas e principalmente quadradas (Fig. 42).

Em face do número de escamas, que ocorre na base, anteriormente citado, as escamas se encontram muito próximas, o que faz com que seus escudos cubram completamente a superfície da epiderme nesta região. (Fig. 42).

$\mathrm{Na}$ margem de qualquer região, onde emerge um acúleo, a forma da célula tende a irregular, o tamanho é pequeno e a disposição torna-se invertida: o eixo maior da célula tem o mesmo sentido do comprimento do acúleo (Fig. 43).

\section{EPIDERME INFERIOR}

REGIÃO MEIO-MEIO:

A epiderme inferior da folha de Aechmea setigera, em vista frontal, apresenta escamas e estômatos, além das células epidérmicas.

As células epidérmicas têm características semelhantes às das células da epiderme superior, nos aspectos já descritos, sendo que os corpos silicosos foram observados principalmente nas células epidérmicas próximas às escamas e estômatos.

As escamas encontram-se distribuídas em faixas uniformes juntamente com os estômatos e células epidérmicas. Estas faixas estão separadas por faixas igualmente uniformes de somente células epidérmicas. Nas faixas, normalmente, as escamas se situam na periferia (em "zig-zag") e o centro é ocupado pelos estômatos; entre escamas e estômatos distribuem-se células epidérmicas (Fig. 44). Os escudos das escamas que se encontram próximas, na mesma faixa, sobrepõem-se, de forma que constituem uma capa sobre os estômatos (Fig. 45).
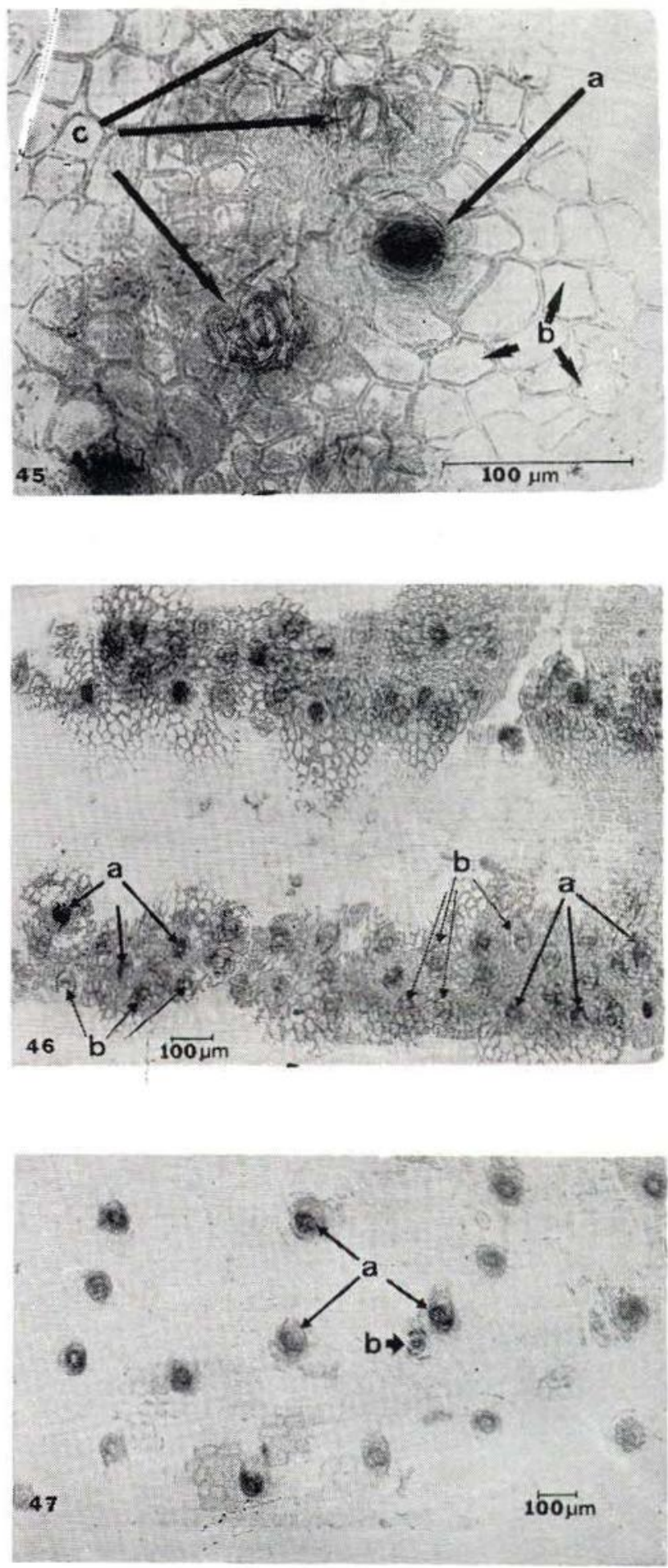

Fig. 45-47 - Aechmea setigera. Epiderme inferior em vista frontal. Fig. 45 - Meio-meio. Estômatos cobertos pelas escamas. a - centro da escama, b - células do escudo e c - estômatos. Fig. $46-$ Ápice-meio. Faixas de escamas, estômatos e células epidérmicas separadas por faixa de apenas células epidérmicas. a - escamas e b - estômatos. Fig. 47 - Base meio. a - escamas e b - estômato. 
A mécila do número de escamas por milímetro quadrado é 13,36 , sendo que a mesma relação para estômatos é de 33,2.

OUTRAS REGIÕES:

A disposição das células epidérmicas das regiōes meio-margem, ápice-meio e ápice-margem mostra-se semelhante a da região meio-meio; são visíveis faixas regulares, em que ocorrem estômatos, escamas e células epidérmicas separadas por faixas, em que estão presentes apenas células epidérmicas (Fig. 46).

Nas regiões base-m€io e base-margem, escamas e estômatos não se dispõem em faixas, mas sim em filas irregulares, apesar desta disposição, os estômatos localizam-se junto às escamas (Fig. 47) .

O maior número de escamas foi encontrado na base, o menor no meio; o número de estômatos cresce da base para o.ápice (Gráfico 2) .

As células epidérmicas da base inferior são como as da base superior, geralmente pequenas e quadradas (Fig. 47).

\section{REGIÃo MEIO-MEIO DA FOLHA EM CORTE} TRANSVERSAL (FIg. 48)

A epicierme superior da folha de Aechmea setigera, em corte transversal, apresenta-se composta de uma camada de células pequenas, pentagonais, com paredes anticlinais e periclinais engrossadas, sendo que a parede periclinal externa é um pouco mais delgada que as demais, de forma cue o lume da céluia, que geraimente tem forma triangular ou lenticular, ocupa uma posição superior em relação ao centro da célula.

Nota-se que as células da epiderme de um modo geral se dispõem lado a lado, em linha reta, com exceção daquelas que margeiam o pedículo de uma escama, neste caso ocupando uma posição vertical, inferior às demais .

Logo abaixo da epiderme tem-se uma hipoderme, cujas células de forma hexagonal possuem paredes muito engrossadas, o que reduz em demasia o lume das mesmas; esta: paredes apresentam uma grande quantidade de pontuações. A seguir, inferiormente, ocor. re uma camada de células pequenas, de forma geralmente irregular, com paredes finas e sem conteúdo aparente.

O parênquima aqüifero, muito reduzidic, encontra-se logo abaixo da camada antericrmente citada, é composto de três a seis camadas de células, sendo que as primeiras são formadas por células principalmente arredondadas, enquanto que as camadas mais internas apresentam células alongadas de paredes delgadas (F̈ig. 49).

O espaço da folha inferior ao parênquima aqüífero é ocupado principalmente por parênquima clorofiliano. Este é constituído de dois tipos de parênquimas distintos: parênquinia clorofiliano propriamente dito e braciforme. O parênquima clorofiliano propriamente dito tem células arredondadas, de tamanho médic. quando comparado com as demais células, de paredes finas e número pequeno de cloroplastos. O parênquima braciforme ocorre imerso entre as células do parênquima clorotiliano, entre os feixes vasculares; ocupa uma larga faixa disposta longitudinalmente. Suas células possuem cerca de seis a oito braços, paredes delgadas e cloroplastos (Fig. 50).

Os feixes vasculares dispõem-se paralelamente uns aos outros, separados pelas faixas do parênquima braciforme e por células do parênquima clorofilianc, que circundam estas últimas (Fig. 50). Situam-se um pouco abaixo da região mediana da folha. Num mesmo corte, pode-se observar a ocorrência de feixes de diversos graus de complexidade. Os mais complexos caracterizam-se por um reforço nas extremidades superior e inferior de fibras esclerenquimáticas mais acentuado, nos menos complexos o reforço da extremidade superior pode faltar; o mesmo aspecto pode-se notar nas células dispostas lateralmente e nas que separam o xilema do floema nos feixes, isto é, quanto mais complexos, paredes mais reforçadas. Outro fator representativo é o maior número de elementos vasculares existentes, pois nos mais desenvolvidos ocorrem cerca de dois a três elementos de vasos de caiibre médio, enquanto que naqueles menos desenvol- 

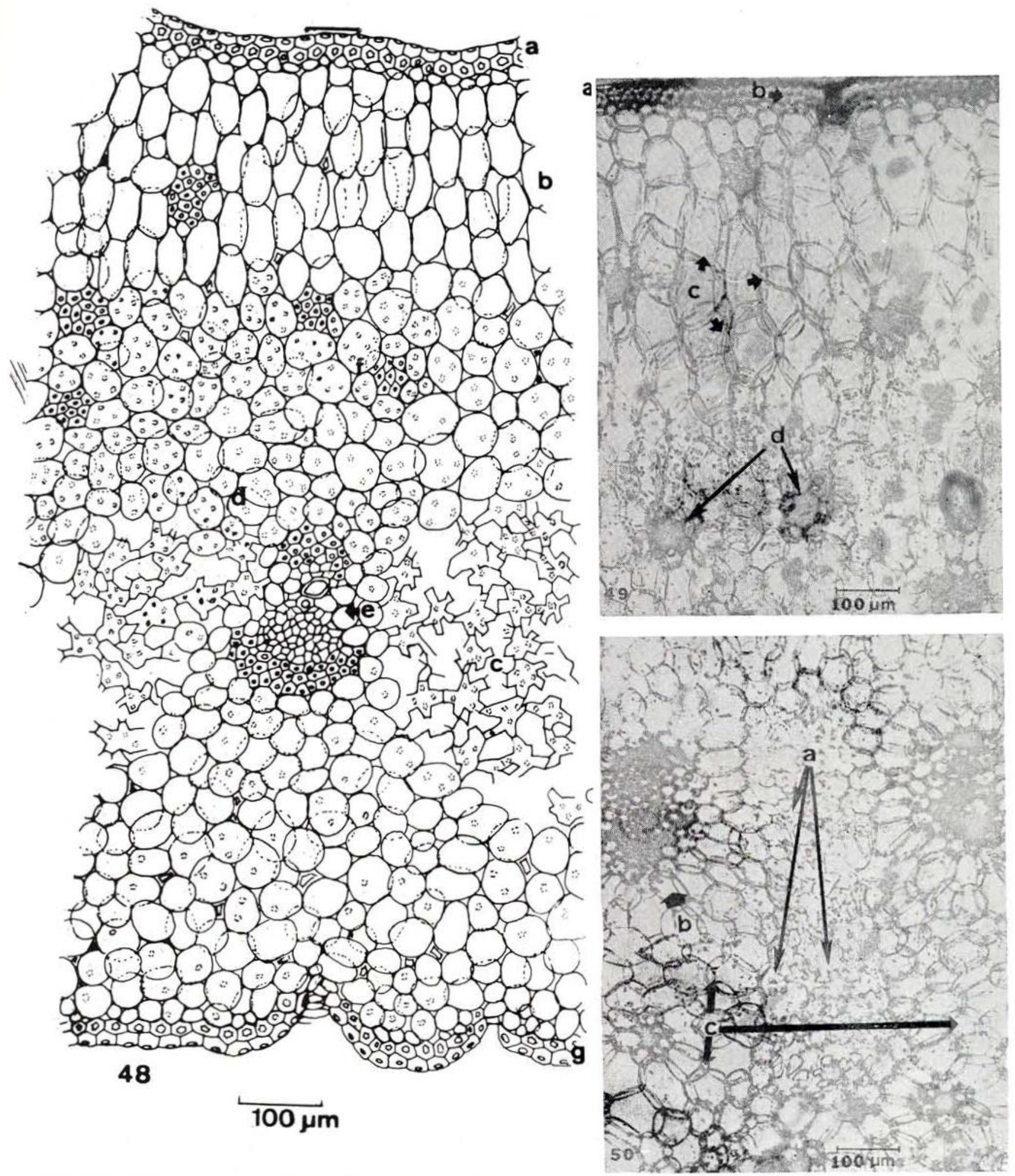

Fig. 48-50 - Aechmea setigera. Fig. 48 - Corte transversal da folha. Meio-meio. Aspecto geral. a - epiderme e hipoderme, b - parênquima aqüífero, $\mathrm{c}$ - parênquima braciforme, $\mathrm{d}$ - parênquima clorofiliano, e feixe vascular, $\mathrm{f}-$ feixes de fibras $\mathrm{e} g-$ hipoderme e epiderme inferiores. Fig. 49 - Corte transversal da rogião meio-meio. a - epiderme, $\mathrm{b}-$ hipoderme, $\mathrm{c}-$ parênquima aquífero e $\mathrm{d}-$ feixes de fibras. Fig. 50 - Corte tran̂sversal da folha. Meio-meio. a - células do parênquima braciforme, $\mathrm{b}$ - feixe vascular e c - parênquima clorofiliano. 

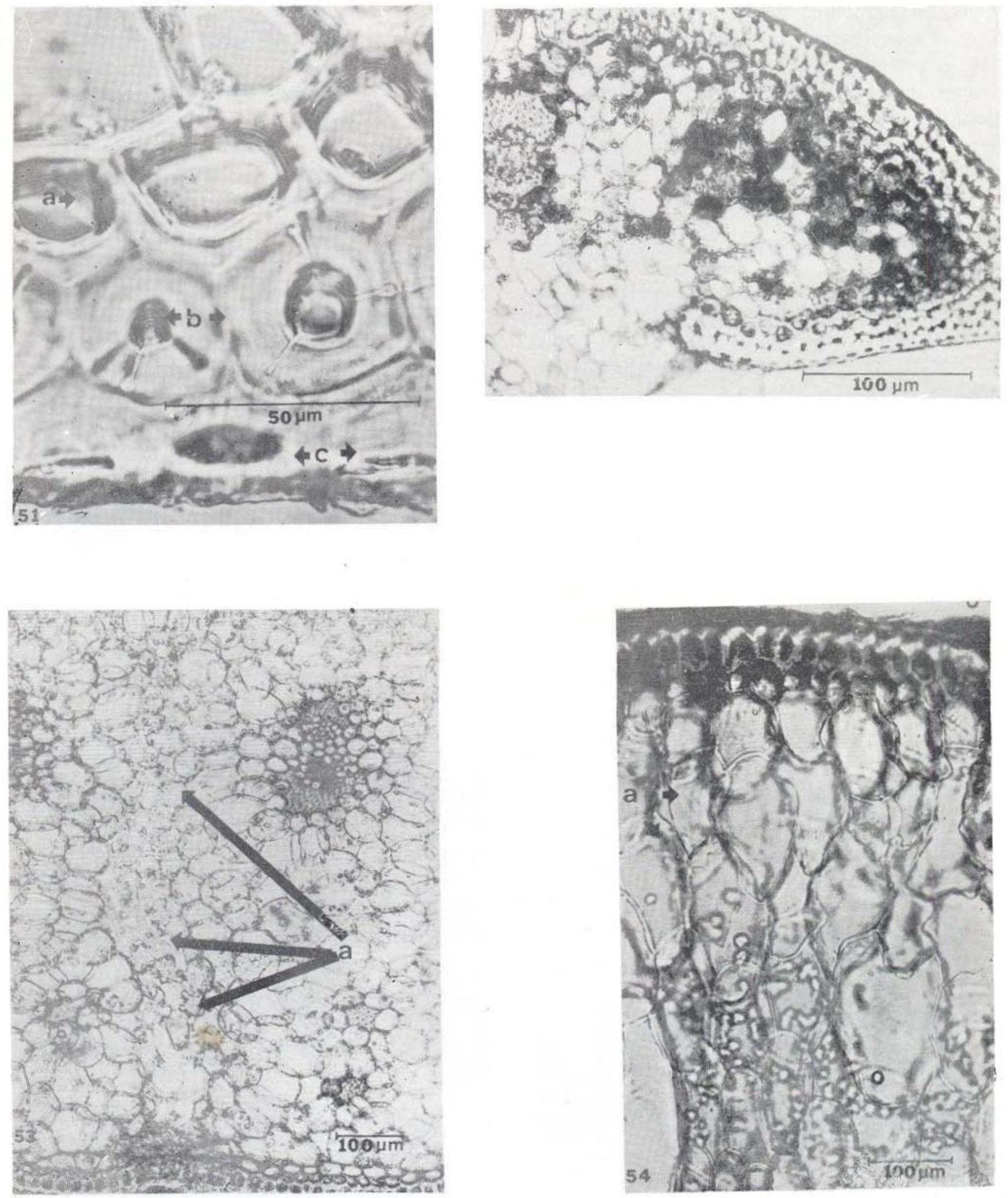

Fig. 51-54 - Aechmea setigera. Fig. 51 - Corte transversal da região meio-meio. Epiderme inferior e camadas vizinhas. a - última camada de células do parênquima clorofiliano, b - hipoderme e c - epiderme. Fig. 52 - Corte transversal da região meio-margem. Aspecto geral. Fig. 53 - Corte transversal da regiâo ápice-meio. a - parênquima braciforme imerso no parênquima clorofiliano. Fig. 54 - Corte transversal da região ápice-meio. a - células do parênquima aquífero. 
vidos, os elementos de vasos não se encontram diferenciados com o aspecto característico; o mesmo pode-se dizer em relação ao floema, que apresenta um maior número de elementos de tubos crivados nos feixes mais desenvolvidos e menor número nos feixes menos desenvolvidos.

Notam-se, às vezes, num corte feixes vasculares, que mantêm comunicação entre feixes vizinhos, atravessando para tal o parênquima braciforme.

É comum a ocorrência de ninhos de fibras esclerenquimáticas espalhadas pelo parêrquima clorofiliano e até mesmo pelo parênquima aqüífero (Fig. 49 e 50).

A última camada de células do parênquima clorofiliano tem características diferentes

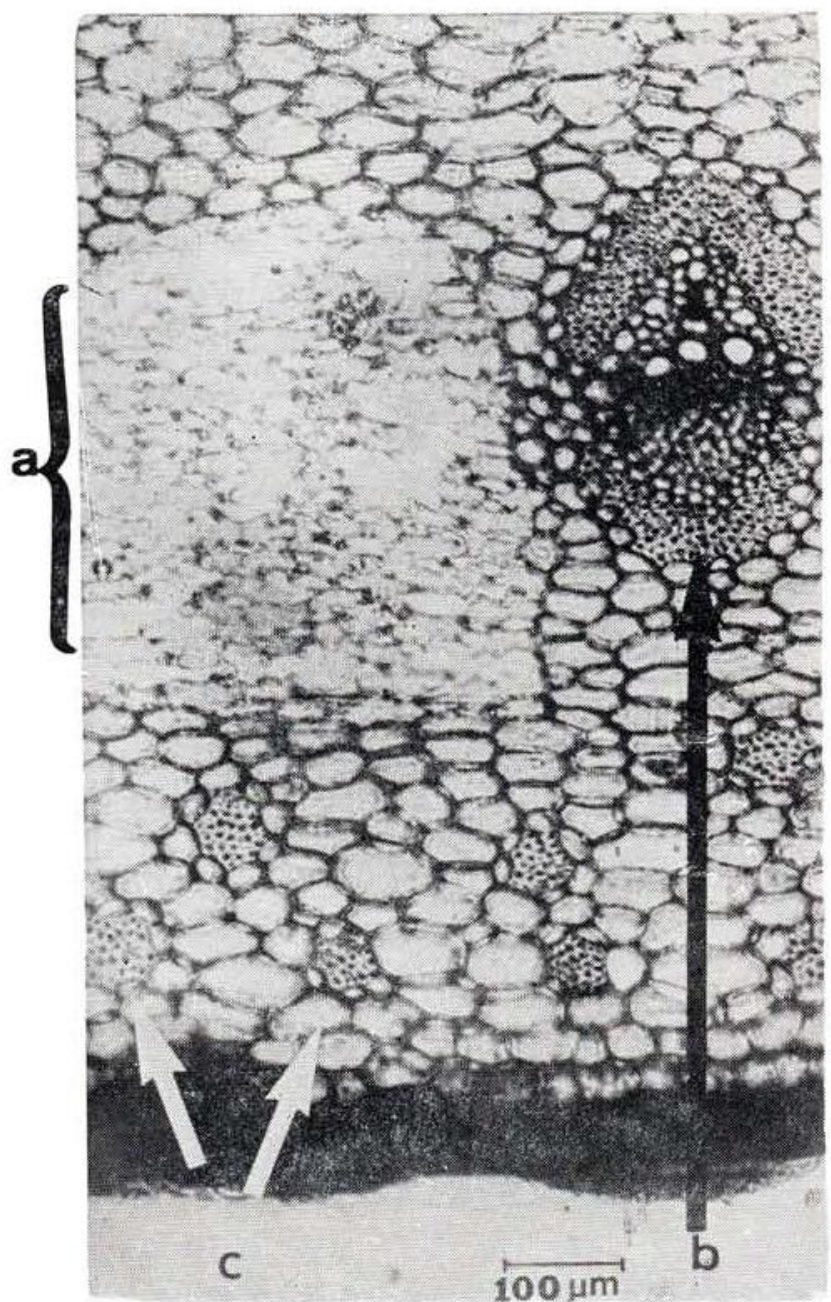

das demais: células pequenas e de paredes um pouco espessas (Fig. 51).

A hipoderme e epiderme inferiores têm aspecto semelhante ao das correspondentes superiores.

REGIÃO MEIO-MARGEM DA FOLHA EM CORTE TRANSVERSAL (Fig. 52)

Nesta região, observam-se algumas diferenças estruturais em relação à organização da zona meio-meio, dentre as quais temos:

- o parênquima aqüífero desaparece, sendo substituído pelo parênquima clorofiliano propriamente dito; também o parênquima braciforme é substituído pelo parênquima clorofiliano.

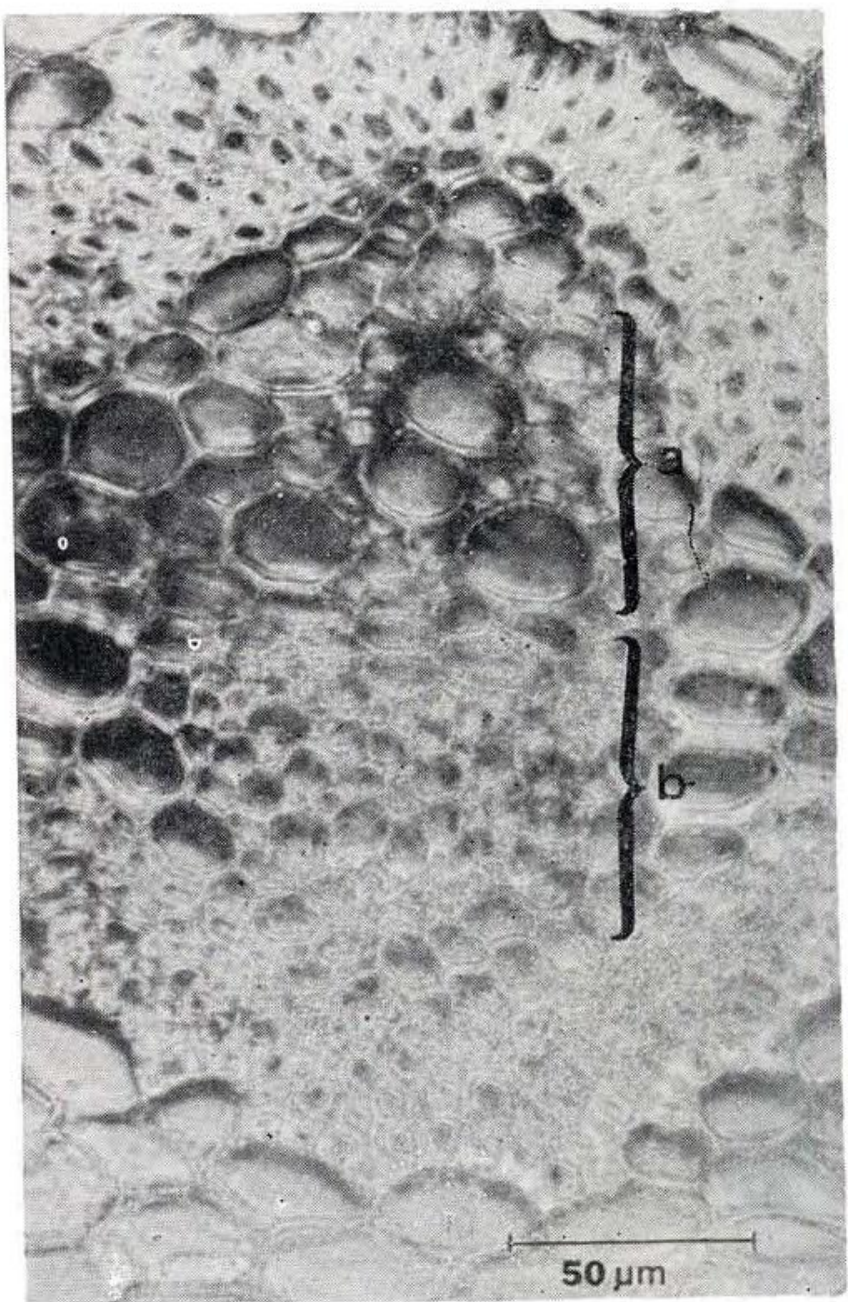

Fig. 55-56 - Aechmea setigera. Corte transversal da região base-meio. Fig. 55 - a - parênquima braciforme, b - feixe vascular, c - feixes de fibras e d - parênquima clorofiliano. Fig. 56 - Feixe vascular principal. a - xilema e b - floema. 
REGIÃo ÁPICE-MEIo DA FOLHA EM CORTE TRANSVERSAL

O aspecto estrutural da região se assemelha ao de meio, apresentando uma única diferença marcante: o parênquima braciforme nesta região é reduzido, constituindo apenas uma faixa estreita no meio do parênquima clorofiliano propriamente dito (Fig. 53) .

O parênquima aqüífero, nas suas camadas interrıs, é facilmente confundido com o parênquima clorofiliano, suas células são aìongadas, mas em muitas, pode-se observar a presença de cloroplastos (Fig. 54).

\section{REGIÃO BASE-MEIO DA FOLHA EM CORTE TRANSVERSAL}

As variaçōes que se nota desta região para meio-meio são:

- a parede periclinal externa das células das epidermes é um pouco mais delgada que a correspondente em meio-meio;

- as células da hipoderme superior apresentam paredes relativamente delgadas;

- o parênquima aqüífero desaparece, sendo a região por ele ocupada, preenchida por células como as do parênquima clorofiliano propriamente dito mas, no caso, sem cloroplastos;

- o parênquima braciforme ocupa um espaço entre os feixes vasculares, quase ao mesmo nivel destes, e o espaço ocupado tem a forma de um quadrado (Fig. 55);

- nos parênquimas correspondentes aos parênquimas clorofiliano e braciforme, não ocorrem cloroplastos, alguns grãos de amido foram observados no primeiro;

- as células da hipoderme inferior têm suas pareaes completamente engrossadas, praticamente sem lume e com muitas pontuações ligando-as às células da camada adjacente superiormente.

Os feixes vasculares apresentam, como na região meio-meio, vários graus de complexidade "em relação ao número de fibras e vasos. A figura 56 mostra um feixe principal.
ESTÔMATOS: VISTA FRONTAL E CORTE TRANSVERSAL E LONGITUDINAL DAS CÉLULAS-GUARDAS

Observando a epiderme inferior em vista frontal da face externa, pode-se constatar que os estômatos estão envolvidos por seis células vizinhas geralmente, sendo duas polares e quatro laterais. Estas células apresentam ou não corpo silicoso e suas paredes normalmente são retilíneas (Fig. 57). Quando dois ou mais estômatos se encontram próximos, as células vizinhas de um podem o ser de outro também.

As figuras 58, 59, 60 e 61 mostram que os estômatos ficam situados abaixo do nivel das demais células da epiderme. Suas células subsidiárias passam por baixo das células estomáticas e, às vezes, é difícil distinguí-las com clareza em vista frontal da epiderme.

$\hat{E}$ interessante notar o espessamento das paredes das células epidérmicas e hipodérmicas, que circundam o estĉmato (Fig. 58 e 59).

O lume das células-guardas, em corte transversal da região mediana das mesmas, mostra-se como uma lente ligeiramente biconvexa (Fig. 58), que se estreita próximo à regiāo polar (Fig. 59) e nesta propriamente dita, ele se amplia.

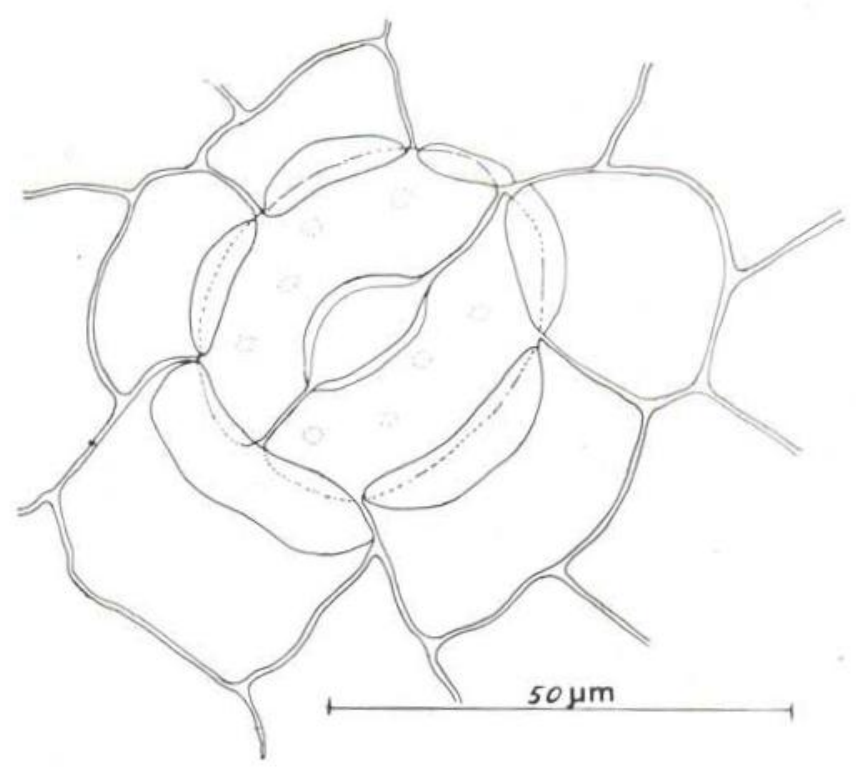

Fig. 57 - Aechmea setigera. Epiderme inferior Estômato e células vizinhas em vista frontal. 
Nas figuras 60 e 61, podem-se observar cortes longitudinais das células-guardas do estômato.

ESCAMAS: VISTA FRONTAL E CORTE TRANSVERSAL

As escamas, em vista frontal, mostram possuir uma forma geralmente arredondada regular ou irregular. É comum verificar-se que as células do escudo tendem a formar camadas concêntricas distintas (Fig. 62).

As células do escudo normalmente são arredondadas ou retangulares, apenas as que se localizam na periferia apresentam-se mais alongadas e com paredes finas, ao contrário das células do centro do estudo, que têm paredes espessas (Fig. 63).
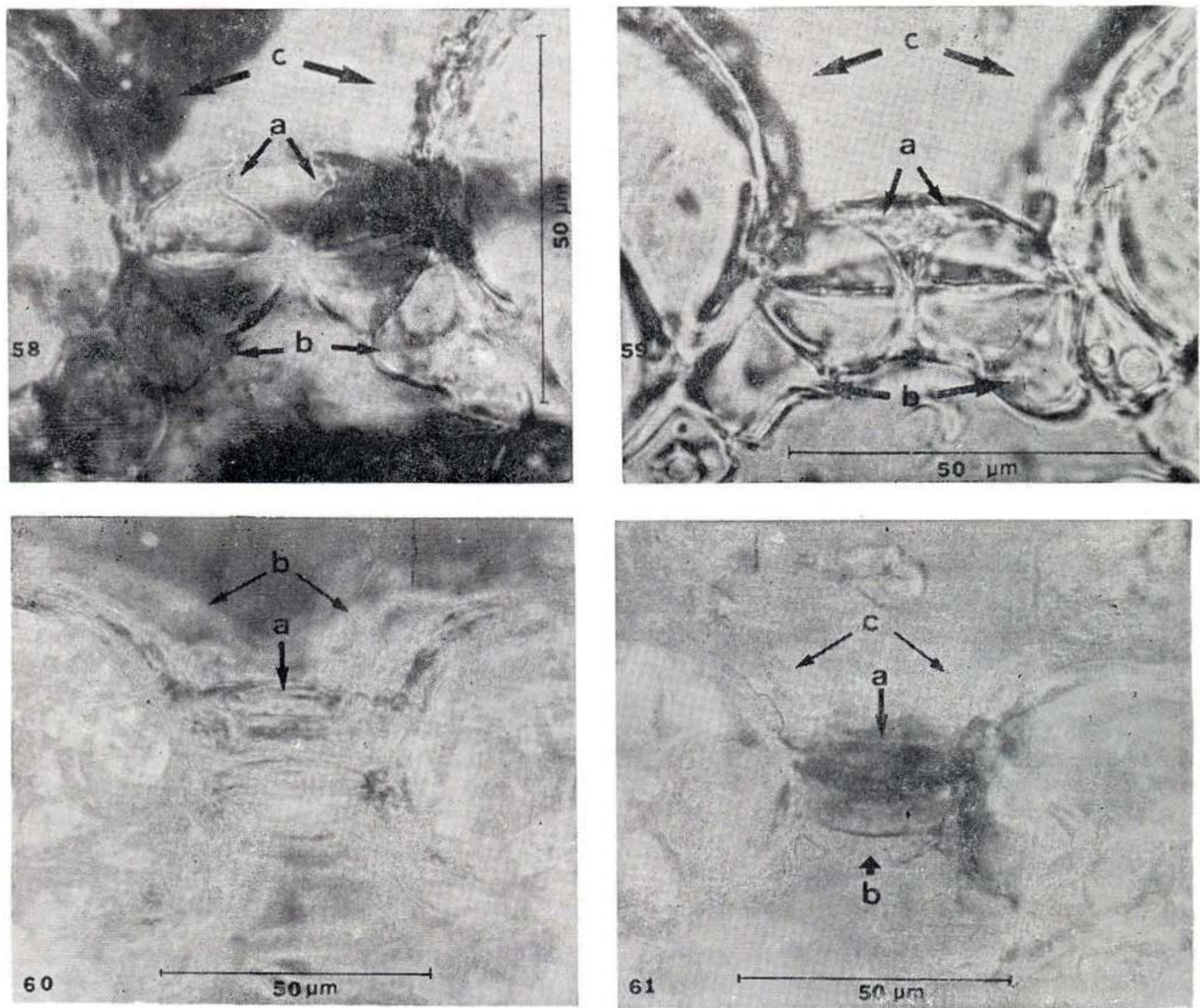

Fig. 58-61 - Aechmea setigera. Corte transversal da região meio-meio. Células-guardas do estòmato em corte transversal na região mediana. a - células-guardas, b - células subsidiárias e c - células vizinhas. Fig. 59 - Corte transversal da região meio-meio. Células-guardas do estômato em corte transversal próximo à região polar. a - células-guardas, b - células subsidiárias e c - células vizinhas. Fig. 60 - Corte longitudinal da região meio-meio. Célula-guarda do estômato em corte longitudinal próximo à parede lateral interna da mesma. a - célula-guarda e b-células vizinhas. Fig. 61 - Corte longitudinal da região meio-meio. Célula-guarda do estômato em corte longitudinal próximo à parede lateral externa da mesma. a - célula-guarda, b - vestígio da célula subșidiária e c - células vizinhas. 

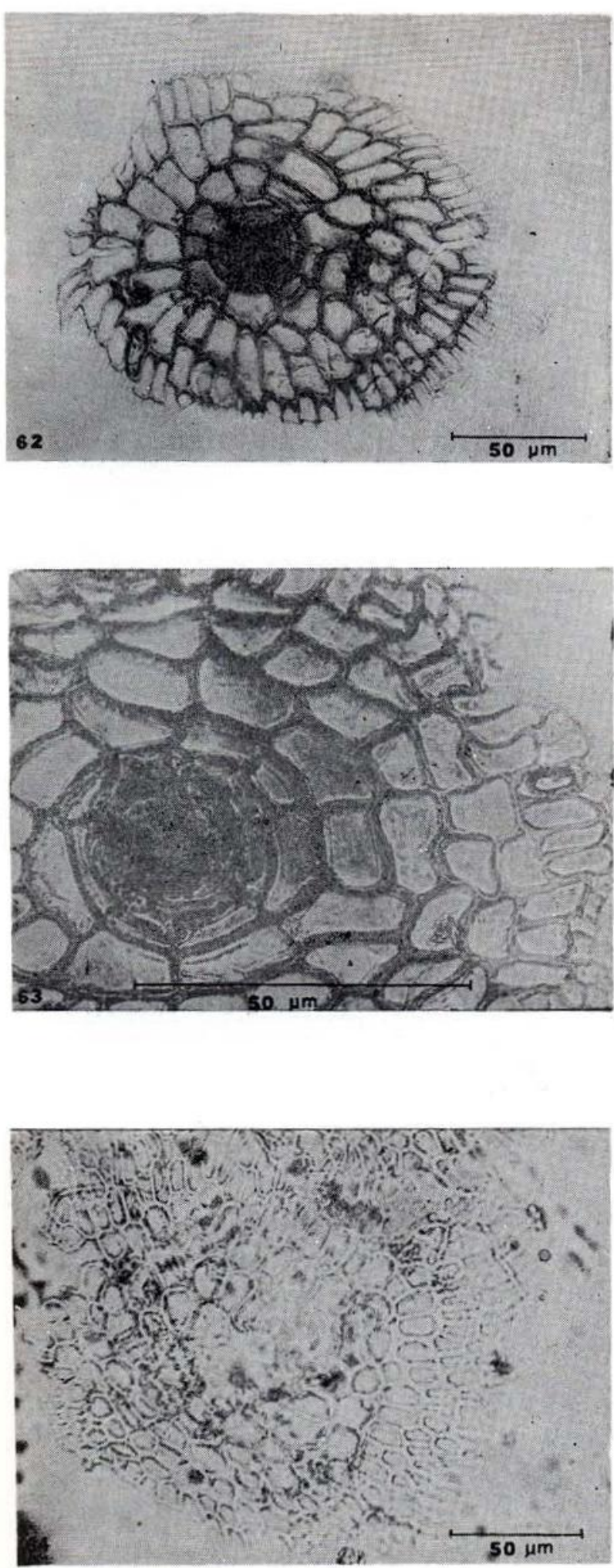

Fig. 62-64 - Aechmea setigera. Fig. 62 - Escama da epiderme superior em vista frontal. Base-margem. Fig. 63 - Escama da epiderme superior em vista trontal. Base-meio. Fig. 64 - Escama da epiderme inferior em vista frontal. Ápice-margem.
As escamas da região meio e ápice têm geralmente um escudo maior (Fig. 64).

Em corte transversal, as escamas mostram ser constituídas de: duas células basais, seis células do pedículo (Fig. 65, 66 e 67) e células do escudo. É interessante notar que

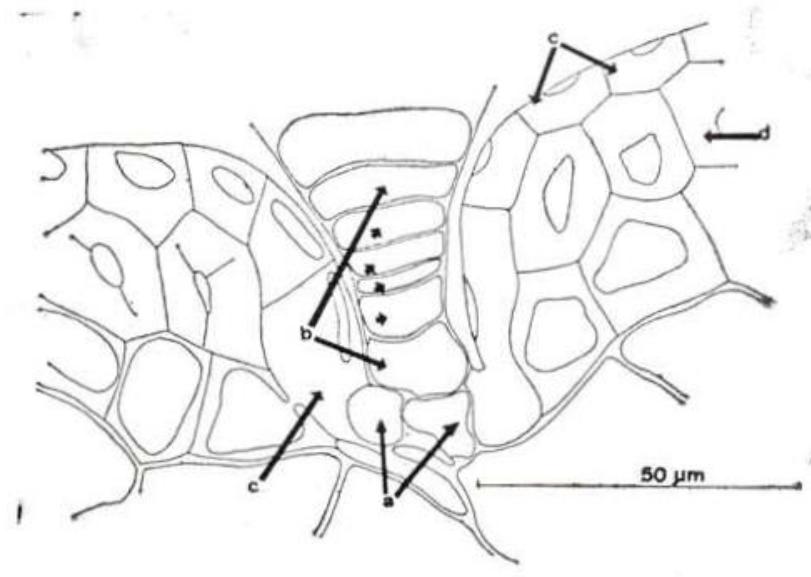

Fig. 65 - Aechmea setigera. Corte transversal da região meio-meio. Escama da epiderme inferior. a - células basais, b - células do pedículo, c - células epidérmicas e d - células hipodérmicas.

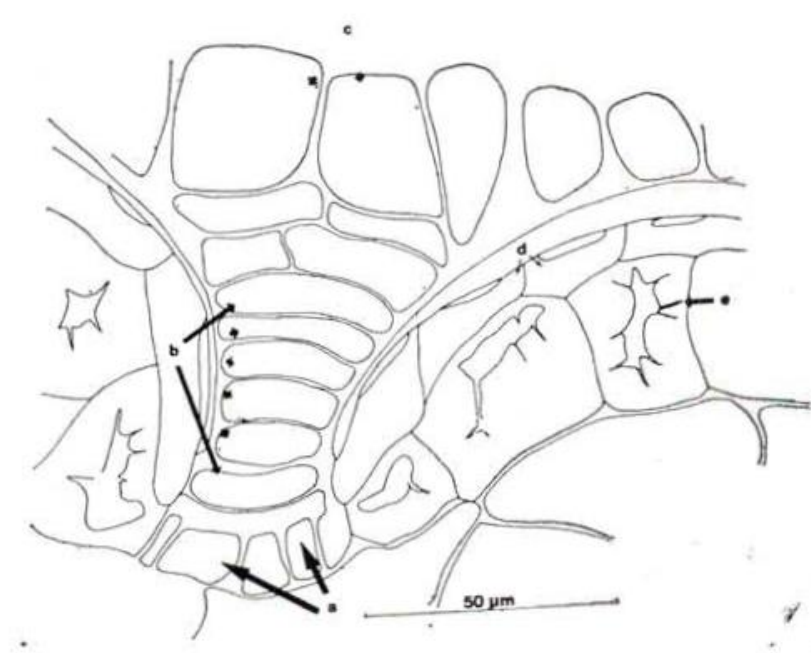

Fig. 66 - Aechmea setigera. Corte transversal da regiāo base-meio. Escama da epiderme inferior. a - células basais, b - células do pedículo, c - células do escudo, d - células epidérmicas e e - células hipodérmicas. 
tanto no meio como na base a parede interna das células basais é espessada e possui muitas pontuações. Nota-se que os espessamentos, que se vê em vista frontal das células do escudo, só ocorrem nas paredes periclinais internas e nas anticlinais das células (Fig. 66).

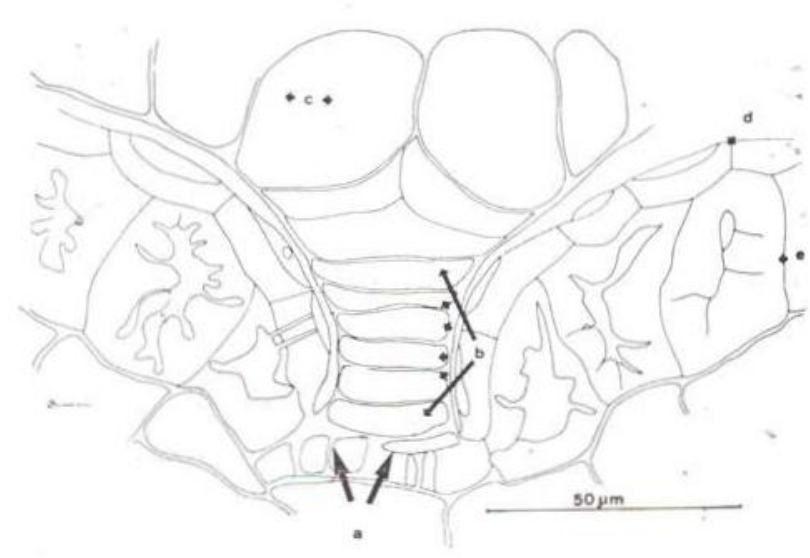

Fig. 67 - Aechmea setigera. Corte transversal da região base-meio. Escama da epiderme inferior. a - células basais, b - células do pedículo, c células do escudo, d - células epidérmicas e e células hipodérmicas.

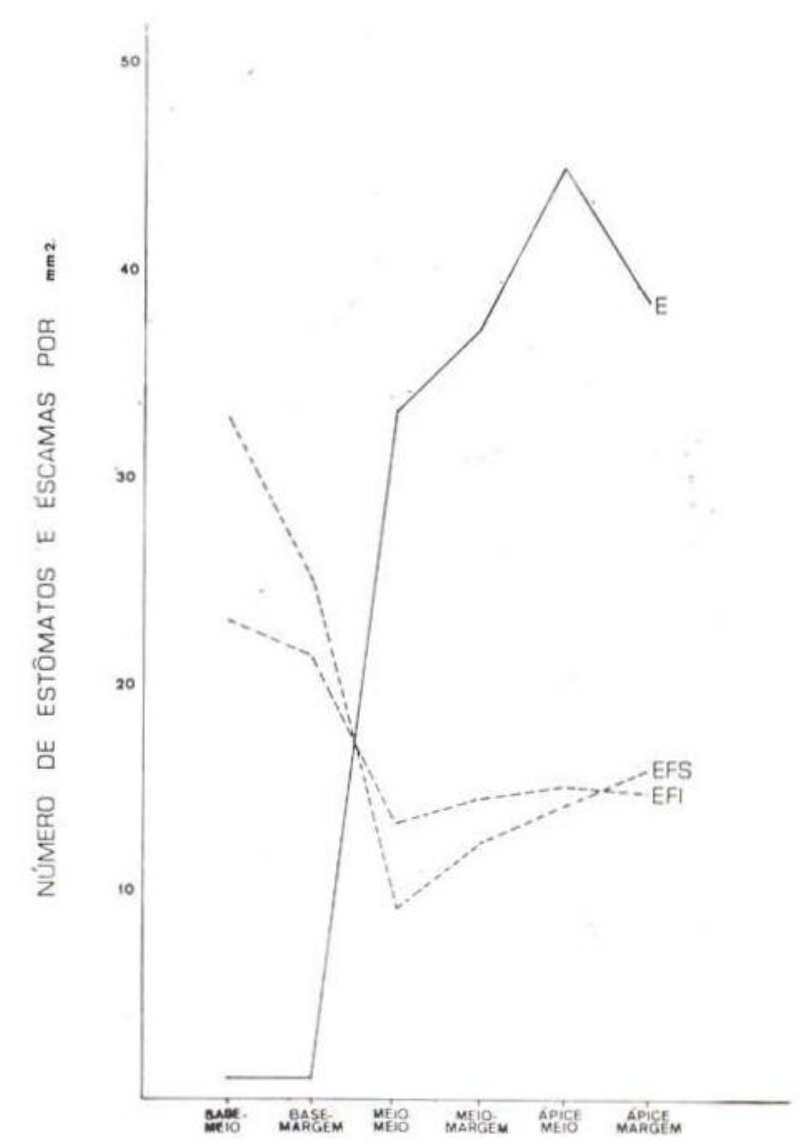

Gráfico 2 - Aechmea setigera. E - méđia do número de estômatos, EFS - média do número de escamas da face superior e EFI - média do númera de escamas da face inferior.

\section{Ananas ananassoides (Baker) L. B. Smith}

\section{EPIDERME SUPERIOR}

\section{REGIÃO MEIO-MEIO:}

A epiderme superior da folha de Ananas ananassoides é provida de escamas (Fig. 68).

As células epidérmicas, em vista frontal, mostram estar distribuídas em filas longitudinais, com o eixo maior da célula disposto no mesmo sentido do comprimento da folha. As células têm a forma quadrada ou retangular, algumas vezes irregular e suas paredes anticlinais são onduladas, lembrando um quebra-cabeça. No lume de cada célula, pode-se observar a presença de um grande corpo silicoso esférico-espinhoso (Fig. 69).
As escamas se dispõem em filas relativamente regulares, regular, também, é o espaço entre duas filas vizinhas e entre duas escamas próximas, na mesma fila.

O resultado da média do número de escamas na região meio-meio foi de 18,4 escamas por milímetro quadrado.

\section{OUTRAS REGIÕES:}

As células das regiões ápice-meio e base-meio têm de um modo geral as mesmas características de meio-meio; meio-margem, ápice-margem e base-margem diferem no seguinte aspecto: quanto mais se aproximam da margem tendem a uma forma retangular mais alongada. 
Quanto ao número de escamas, verificouse que a região que apresentou maior número foi a base, região apical tem um número semelhante ao meio (Fig. 70).

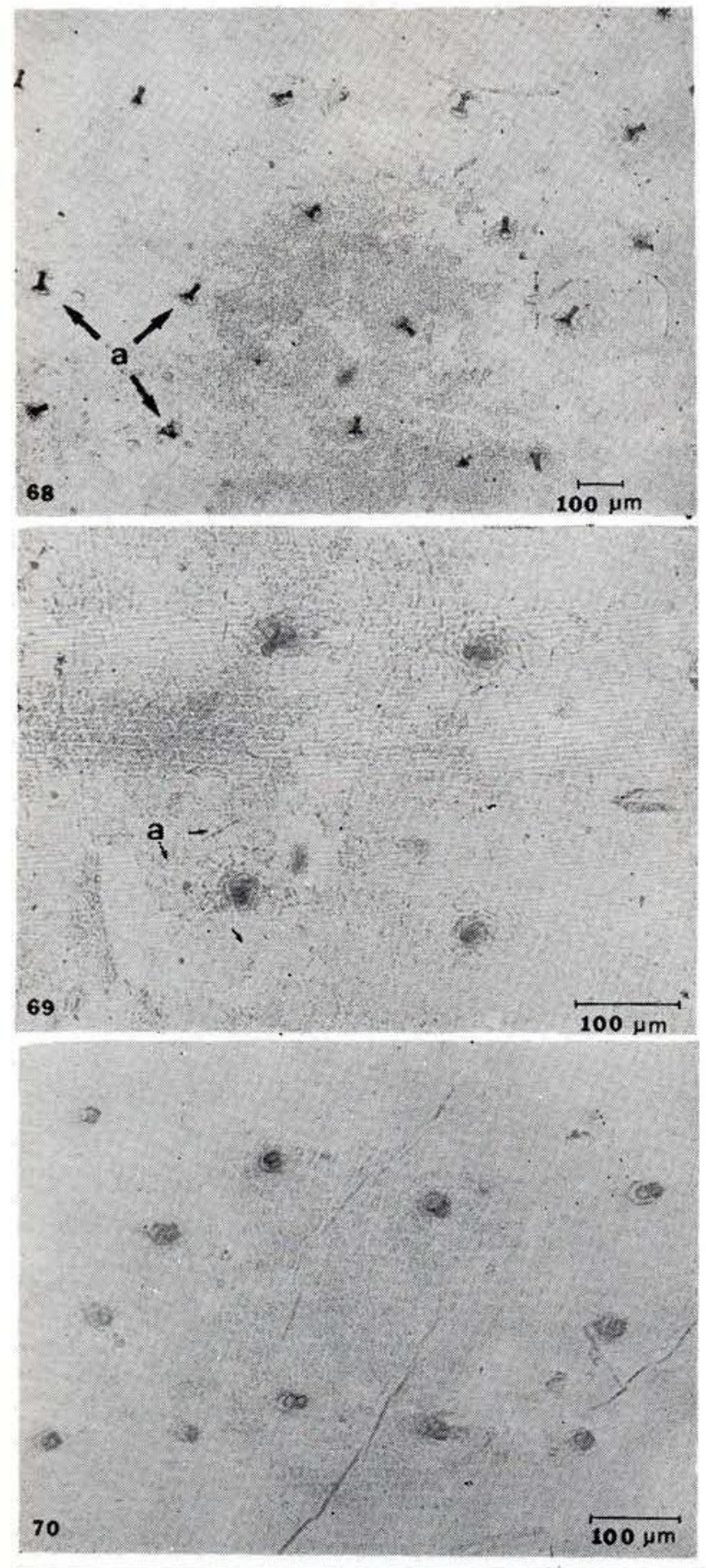

Fig. 68-70 - Ananas ananassoides. Epiderme superior em vista frontal. Fig. 68 - Meio-meio. Células epidérmicas e escamas. a - pedicelos de escamas. Fig. 69 - Meio-meio. Observar paredes anticlinais das células onduladas. a - corpos silicosos. Fig. 70 - Base-margem. Variação do número de escamas comparadas com de outras regiōes.
Foi notada a ocorrência de estruturas parecidas com estômatos na epiderme superior da região base-meio, de duas das cinco folhas utilizadas para contagem de escamas, numa média de 0,4 por milímetro quadrado.

Nas regiões onde emerge um acúleo, as células epidérmicas têm sua forma irregular, o tamanho pequeno e orientam-se no mesmo sentido do acúleo.

A figura 71 mostra os corpos silicosos das células epidérmicas.

\section{EPIDERME INFERIOR}

\section{REGIÃO MEIO-MEIO:}

A epiderme inferior de Ananas ananassoides é provida de escamas e estômatos (Fig. 73).

As células epidérmicas têm características semelhantes às das células da epiderme superior, no que concerne à disposição, forma, tamanho, parede e conteúdo (Fig. 72).

As escamas, estômatos e parte das células epidérmicas ocorrem em faixas longitudinais, que se alternam com faixas de apenas células epidérmicas. As faixas de escamas, estômatos e células epidérmicas são geralmente um pouco mais largas que as de células epidérmicas (Fig. 72). As células epidérmicas das faixas de escamas e estômatos tendem a uma forma irregular.

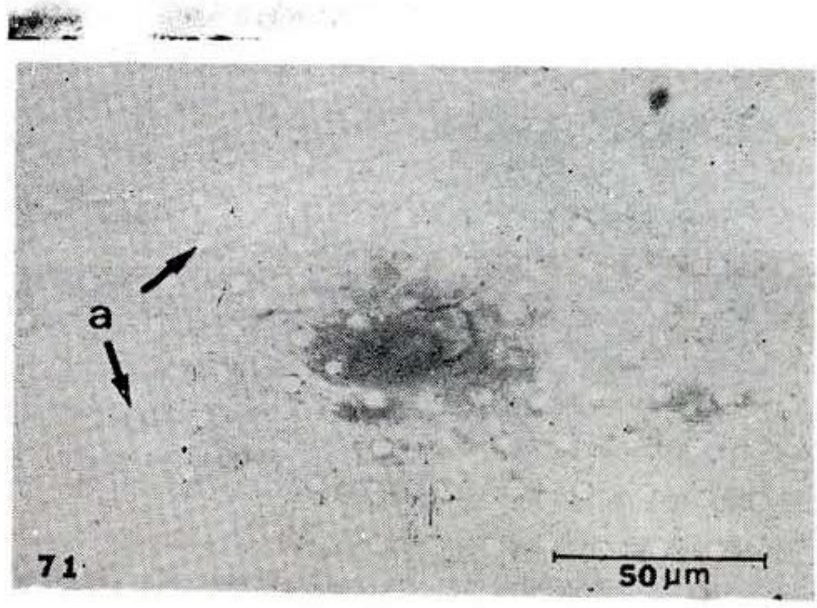

Fig. 71 - Ananas ananassoides - Epiderme superior em vista frontal. Base-meio. a - corpos silicosos nas células da epiderme. 


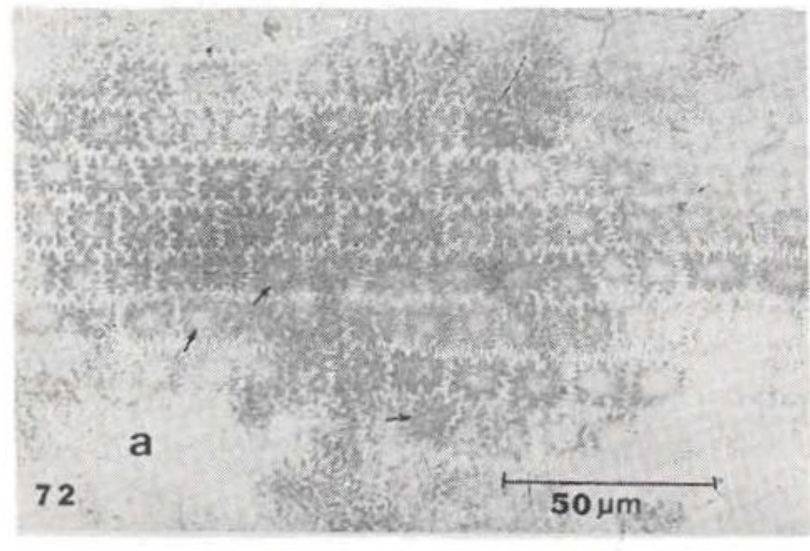

Fig. 72 - Ananas ananassoides. Epiderme inferior em vista frontal. Meio-meio. a - células epidérmicas.

De um modo geral, as escamas ocupam a posição periférica nas faixas e os estômatos, a posição central.

Os escudos das escamas são grandes e como escamas e estômatos ocorrem próximos, estes ficam cobertos por aqueles (Fig. 73).

A média do número de escamas que ocorrem nesta região por milímetro quadrado foi de 28,52 e a de estômatos 57,32 .

\section{OUTRAS REGIÕES:}

Em meio-margem e ápice-margem, geralmente, as faixas de escamas, estômatos e células epidérmicas são mais irregulares, ora estreitas, ora largas. No ápice-meio, o aspecto da epiderme é similar a meio-meio (Fig. 74). $\mathrm{Na}$ base-meio e base-margem, as faixas estão praticamente reduzidas a filas uni (Fig. 75) ou bisseriadas com grande espaço entre uma fila e outra.

O número de escamas aumenta, na epiderme inferior da base para o ápice, o mesmo acontece com o número de estômatos, sendo que, no ápice-margem, a média tanto de escamas como de estômatos é menor que em meio-margem (Gráfico 3).

\section{REGIÃO MEIO-MEIO DA FOLHA EM CORT? TRANSVERSAL}

A epiderme superior da folha, região meio-meio, em corte transversal apresenta-se constituída de uma camada de células peque-
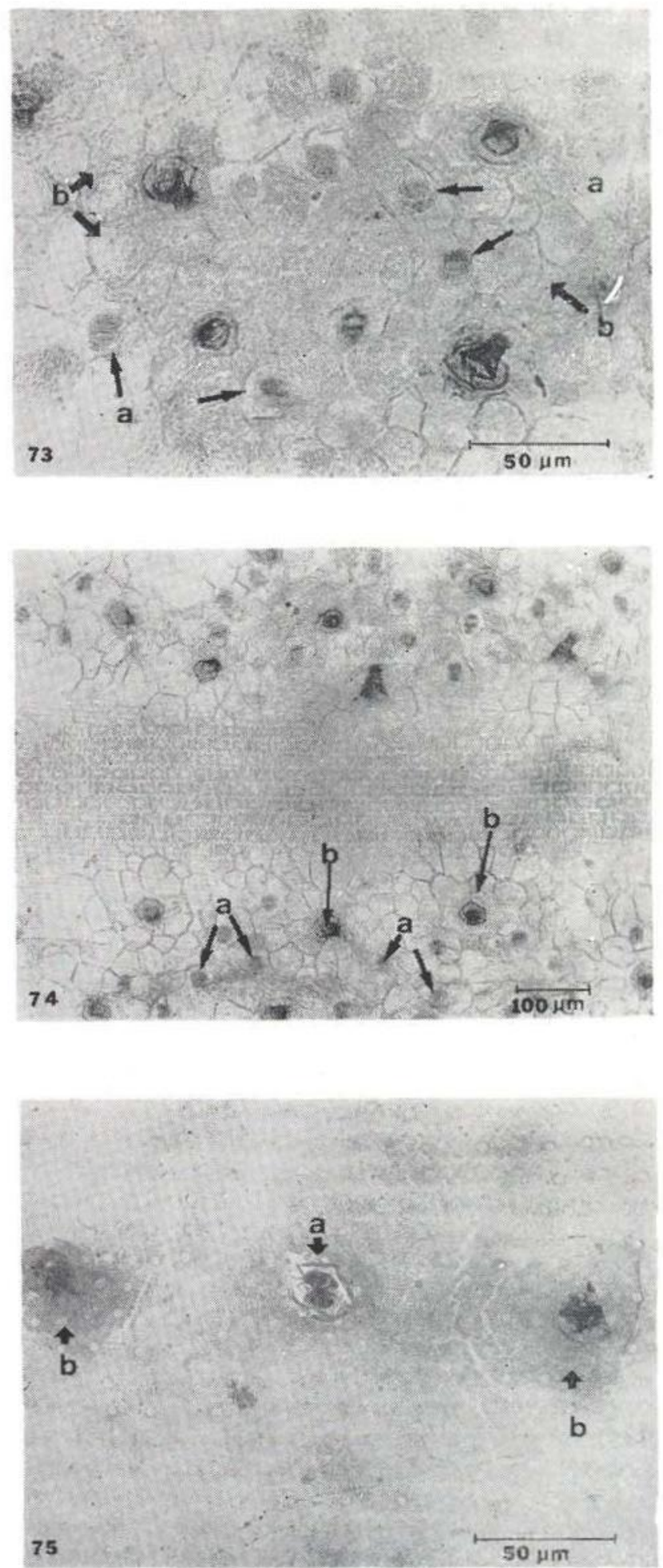

Fig. - 73-75 - Ananas ananassoides. Epiderme inferior em vista frontal. Fig. 73 - Meio-meio. a estômatos cobertos por b - escudos das escamas. Fig. 74 - Ápice-meio. Faixas de estômatos, escamas e células epidérmicas separadas por faixa de células epidérmicas. a - estômatos e b - escamas. Fig. 75 - Base-meio, a - estômato e b - escamas. 

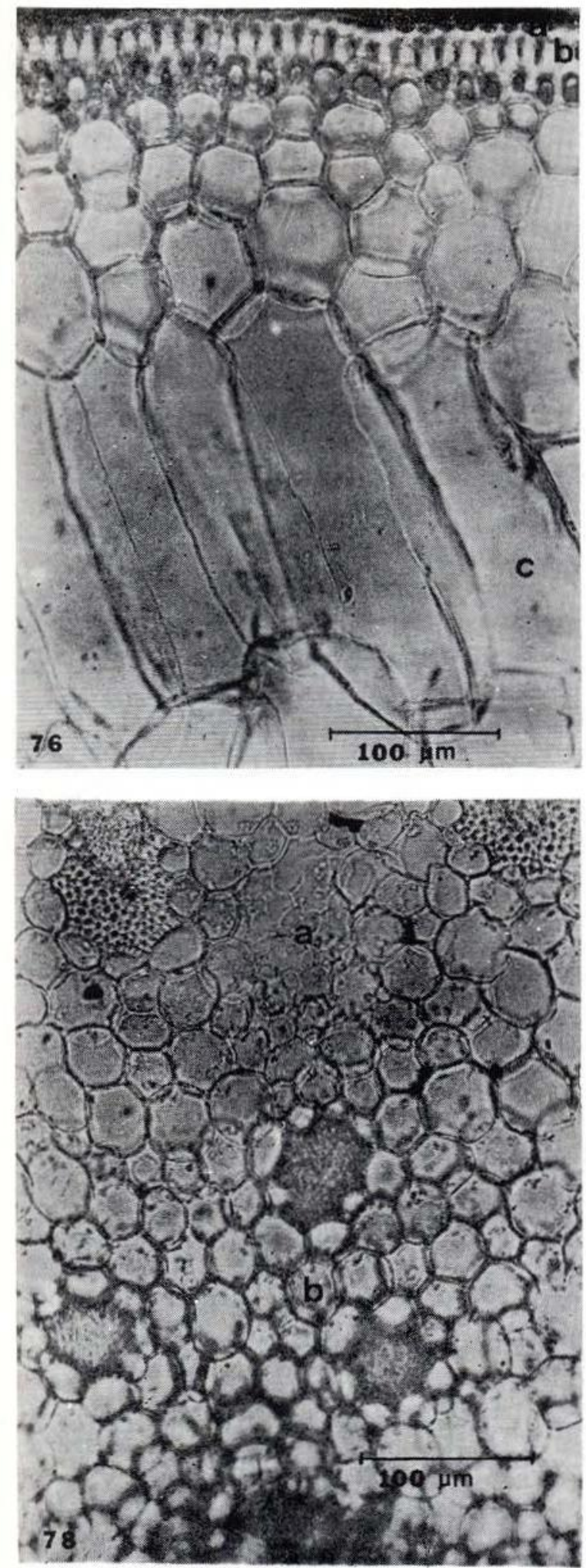
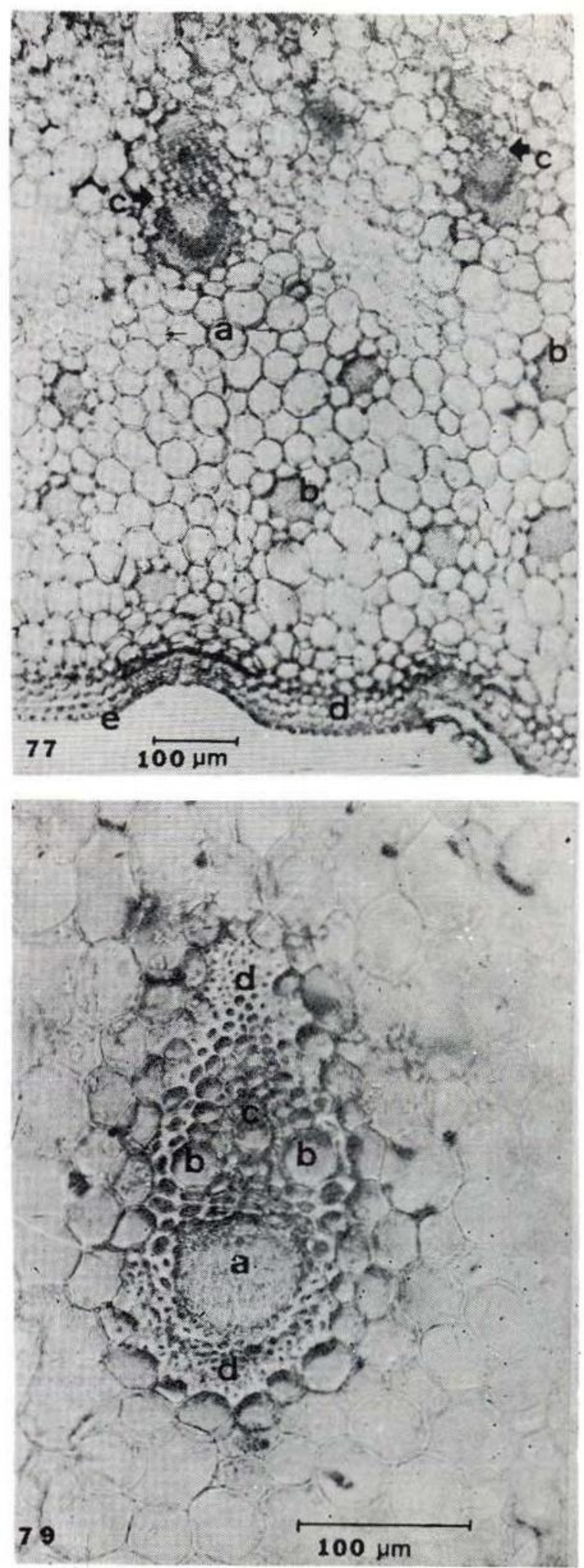

Fig. 76-79 - Ananas ananassoides. Corte iransversal da região meio-meio. Fig. 76 - a - epiderme, b - hipoderme e c - parênquima aquífero. Fig. 77 - a - parênquima clorofiliano, b - feixes de fibras, c - feixes vassculares, d - hipoderme e e - epiderme inferior. Fig. $78-a-$ parênquima braciforme e b - parênquima clorofiliano. Fig. 79 - Feixe vascular. a - floema, b - elemento de vaso do metaxilema, c - elemento de vaso do protoxilema e d - reforço de fibras 
nas, pentagonais, com paredes anticlinais e periclinal interna espessas e parede periclinal externa delgada (Fig. 76), o lume da célula é oval e portador de um grande corpo silicoso. As células da epiderme dispõem-se em linha reta, apenas alterando esta situação nas regiōes onde ocorre uma escama, pois as células contornam a base da escama que se situa em nível inferior em relação às demais células da epiderme.

Abaixo da epiderme encontra-se a hipoderme - uma camada de células de aspecto muito regular, com forma hexagonal, paredes espessas com pontuações e lume reduzido (Fig. 76).

A terceira camada é composta de células arredondadas, podendo variar em relação a este aspecto e quanto ao tamanhc, paredes espessas com pontuações e lume celular grande (Fig. 76).

Nas três camadas seguintes as células aumentam sucessivamente de tamanho e suas paredes mostram-se mais finas, a forma das céluias é variável: pentagonal, hexagonal ou heptagonal e sem espaço intercelular (Fig. 76).

O parênquima aqüífero organiza-se com três ou quatro camadas de células cilíndricas de paredes finas, que ocupam quase toda a metade superior da folha. Essas céluias geralmente têm sua altura duas a três vezes maior que o diâmetro (Fig. 76).

O parênquima clorofiliano (Fig. 77) é uma continuação do parênquima aqüifero, ocupa a metade inferior do mesófilo e nele estão distribuídos feixes vasculares e feixes esclerenquimáticos.

O parênquima clorofiliano é constituído de dois tipos de parênquimas: parênquima clorofiliano propriamente dito e parênquima braciforme. As células do parênquima clorofiliano propriamente dito são pequenas, arredondadas e com paredes delgadas. As do parênquima braciforme possuem de cinco a sete braços curtos, de forma que as lacunas que ficam entre as células são pequenas e o espaço ocupado por este tecido também o é. As células do parênquima braciforme não formam um "canal" contínuo até os estômatos (Fig. 77 e 78).

Verifica-se, freqüentemente, a presença de ninhos de fibras esclerenquimáticas espalhadas por todo o parênquima clorofiliano (Fig. 77 e 78).

Os feixes vasculares ocorrem na região mediana da folha mergulhados no parênquima clorofiliano. Estão dispostos paralelamente um ao outro e, lado a lado, encontram-se feixes mais desenvolvidos e menos desenvolvidos. Aqueles caracterizam-se por um reforço central e periférico de fibras esclerenquimáticas e número de vasos maior (F!g. 79), esses últimos exatamente pelo contrário. O protoxilema é representado por um elemento de vaso que normalmente ocupa uma posição su-
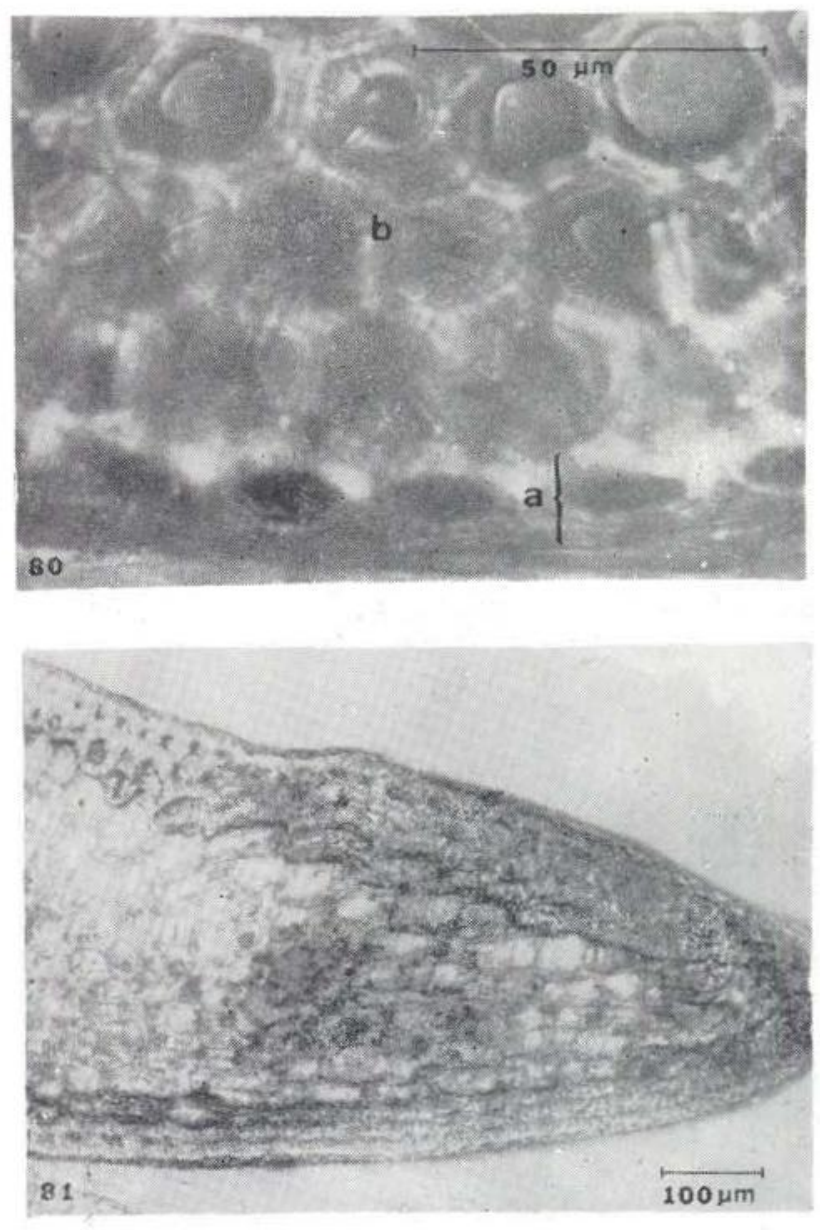

Fig. 80-81 - Ananas ananassoides. Fig. 80 - Corte transversal da região meio-meio. a - epiderme inferior e b - hipoderme. Fig. 31 - Corte transversal da regiấo meio-margem no local de saída de um acúleo. 

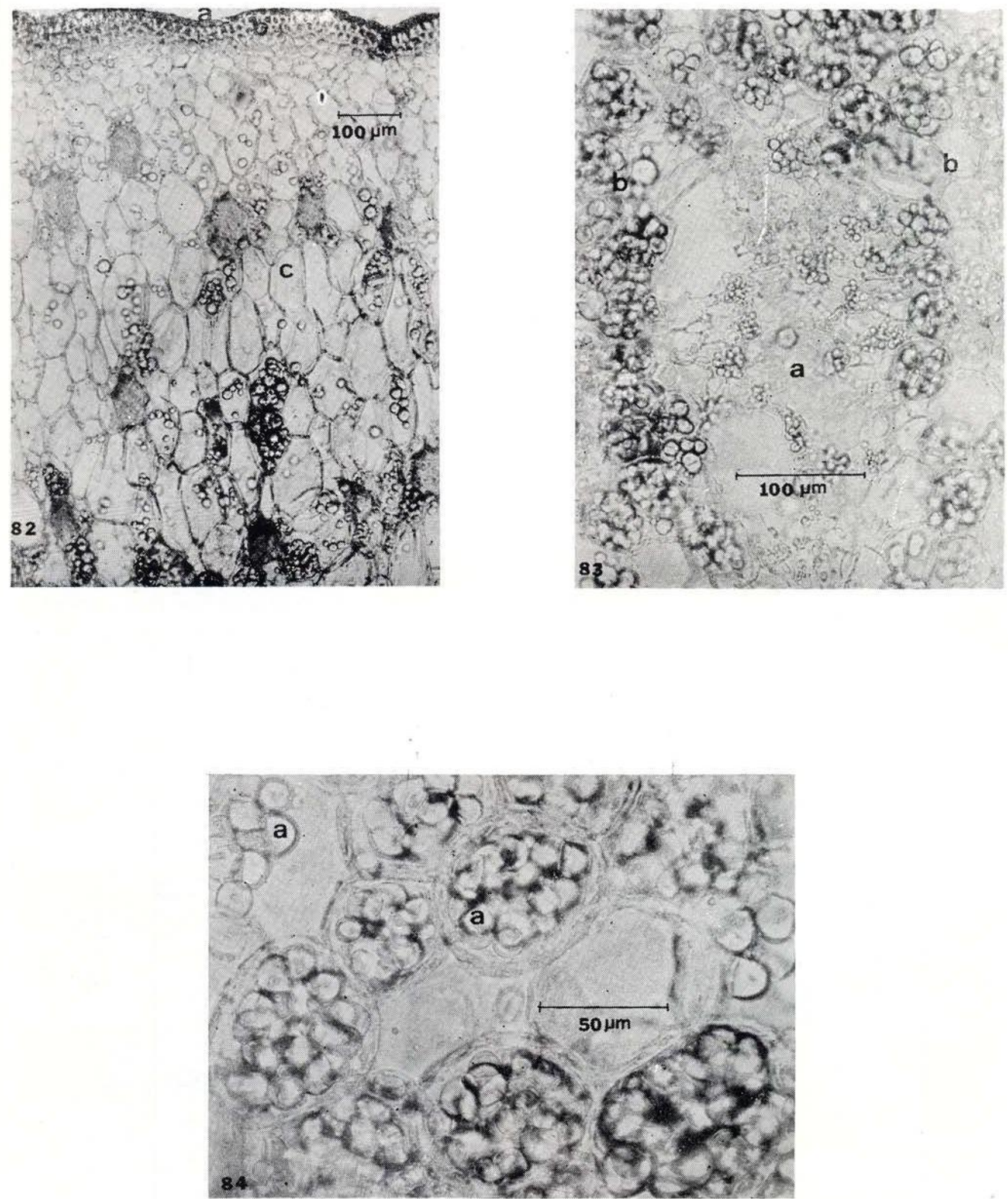

Fig. 82-84 - Ananas ananassoides. Corte transversal da região base-meio. Fig. 82 - a - epiderme superior, b - hipoderme e c - parênquima aqüífero. Fig. $83-$ a - parênquima braciforme e b - parênquima clorofiliano. Fig. $84-$ a - grãos de amido em células do parênquima clorofiliano. 
perior e mediana no feixe em relação ao metaxilema. Este é constituído de dois ou mais elementos de vasos. Algumas células parênquimáticas envolvem os elementos de vasos do xilema. Em volta do xilema e floema, inclusive separando estes dois, observam-se células com paredes espessas e com muitas pontuações. Um reforço de fibras, com diâmetro menor, encontra-se nos polos do feixe vascular (Fig. 79).

A última camada de células do parênquima clorofiliano possui células pequenas e com paredes espessas, cheias de pontuações e lume reduzido (Fig. 80).

A epiderme inferior tem o mesmo aspecto da epiderme superior, diferindo desta por apresentar estômatos em reentrâncias de espaço em espaço.

\section{REGIÃO MEIO-MARGEM DA FOLHA EM CORTE} TRANSVERSAL (Fig. 81)

As células do parênquima aqüifero aos poucos apresentam sua altura reduzida até ficarem com o aspecto similar ao das células do parênquima clorofiliano propriamente dito.

Cerca de $1,5 \mathrm{~mm}$ próximo da margem desaparecem os feixes de fibras esclerenquimáticas.

\section{REGIÃo ÁPICE-MEIO DA FOLHA EM CORTE TRANSVERSAL}

Não se verificaram diferenças marcantes que pudessem distinguir esta região da região meio-meio.

\section{REGIÃO BASE-MEIO DA FOLHA EM CORTE} TRANSVERSAL

A folha nesta região apresenta o dobro de espessura que das outras regiões.

As células localizadas acima do parênquima aqüífero, próximas da hipoderme, ocorrem em número de camadas maior, cerca de oito camadas, às vezes contendo grãos de amido (Fig. 82).

O parênquima braciforme ocupa um espaço relativamente maior (Fig. 83 ).

As células dos parênquimas clorofiliano, braciforme e aqüífero, principalmente próximos aos feixes vasculares, encontram-se repletas de grãos de amido, estes podem ser geminados, trigeminados ou isolados (Fig. 84).

Verifica-se maior número de ninhos de fibras esclerenquimáticas na região entre parênquima aqüífero e clorofiliano (Fig. 82).

ESTÔMATOS: VISTA FRONTAL E CORTE TRANSVERSAL E LONGITUDINAL

Em vista frontal da epiderme inferior observa-se que os estômatos se encontram numa depressão da epiderme. Esta depressâo é circundada por células epidérmicas situadas no plano vertical, têm geralmente paredes onduladas e portam em seu lume um grande corpo silicoso.

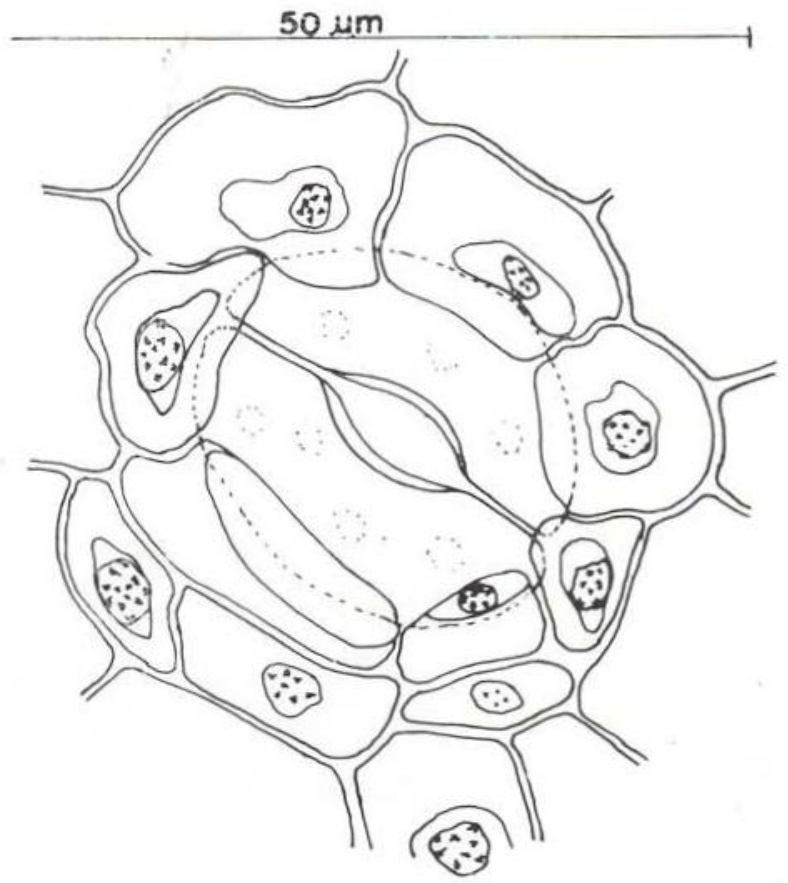

Fig. 85 - Ananas ananassoides. Epiderme inferior. Meio-meio. Estômato e células vizinhas em vista frontal. 

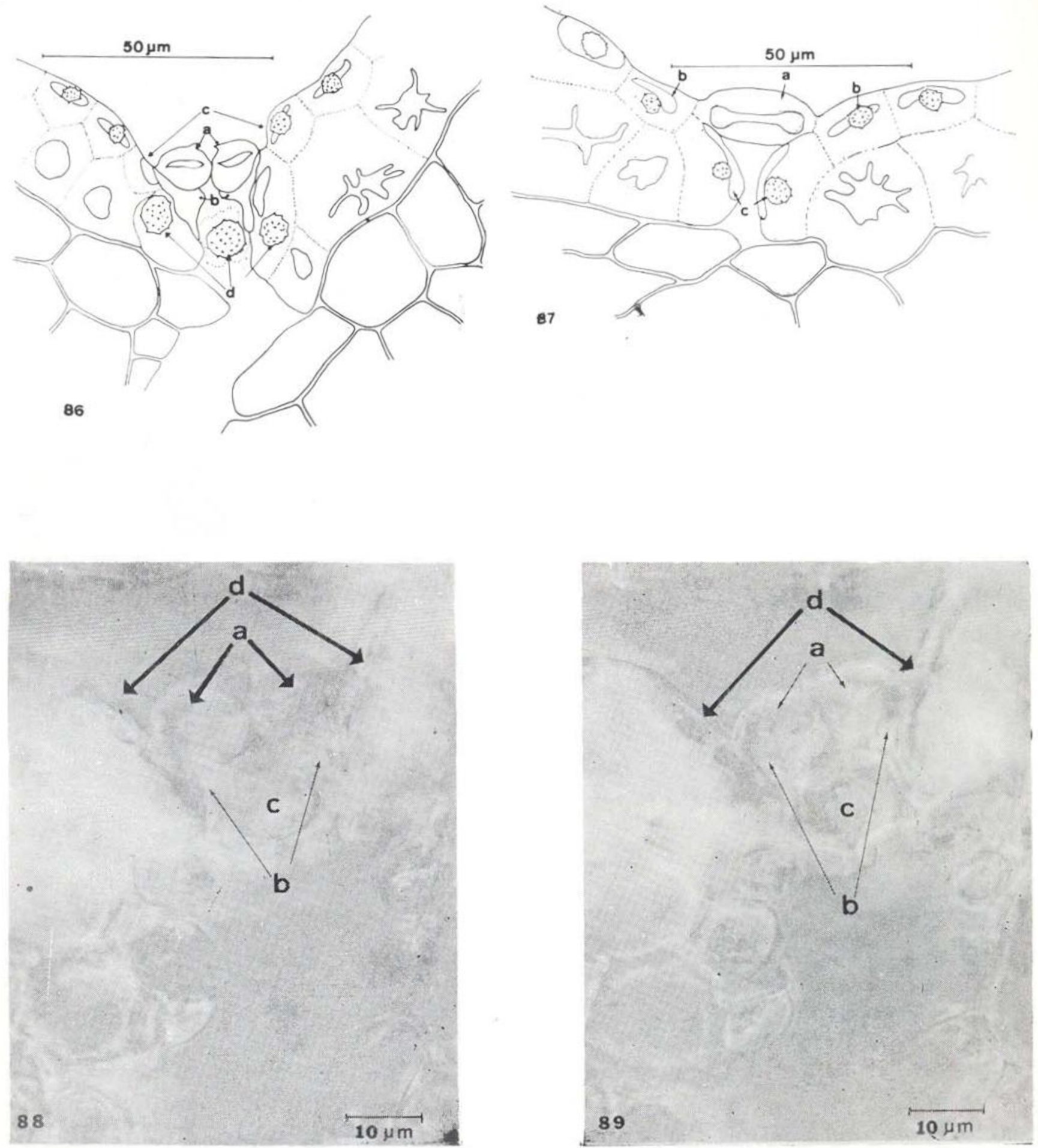

Fig. 86-89 - Ananas ananassoides. Estômato. Fig. 86 - Corte transversal da região mediana das células-guardas, a - células-guardas, b - células subsidiárias, c - células vizinhas e d - corpos silicosos. Fig. 87 - Corte longitudinal de ums célula-guarda. a - célula-guarda, b - células vizinhas e c - corpos silicosos. Fig. 88 - Corte transversal das células-guardas em sua região mediana. a - células-guardas, b células subsidiárias, c - corpo silicoso e d - células vizinhas. Fig. 89 - Corte transversal das células-guardas em sua região polar. a - céluias-guardas, b - células subsidiárias, c - corpo silicoso e d - células vizinhas. 

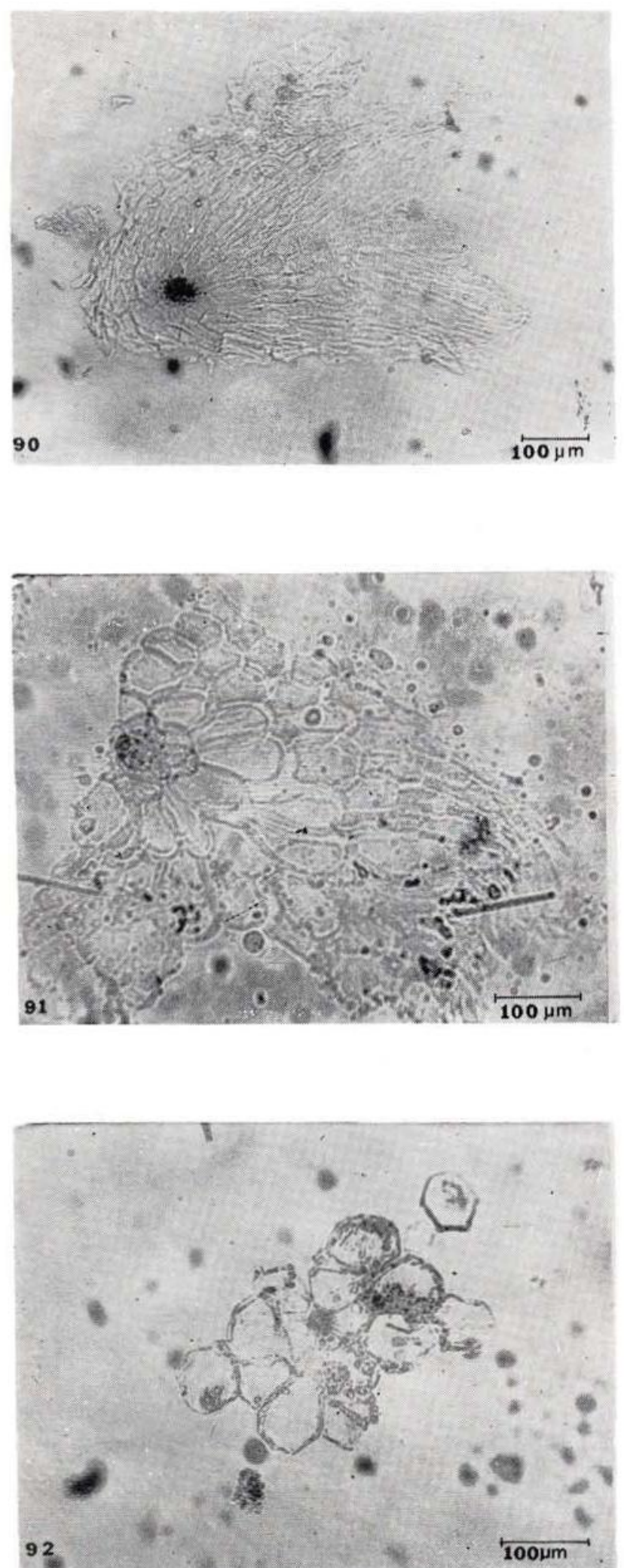

Fig. 90-92 - Ananas ananassoides. Escamas em vista frontal. Fig. 90 - Epiderme superior. Base-margem. Fig. 91 - Epiderme superior. Base-meio. Fig. 92 - Epiderme inferior. Ápice-margem.
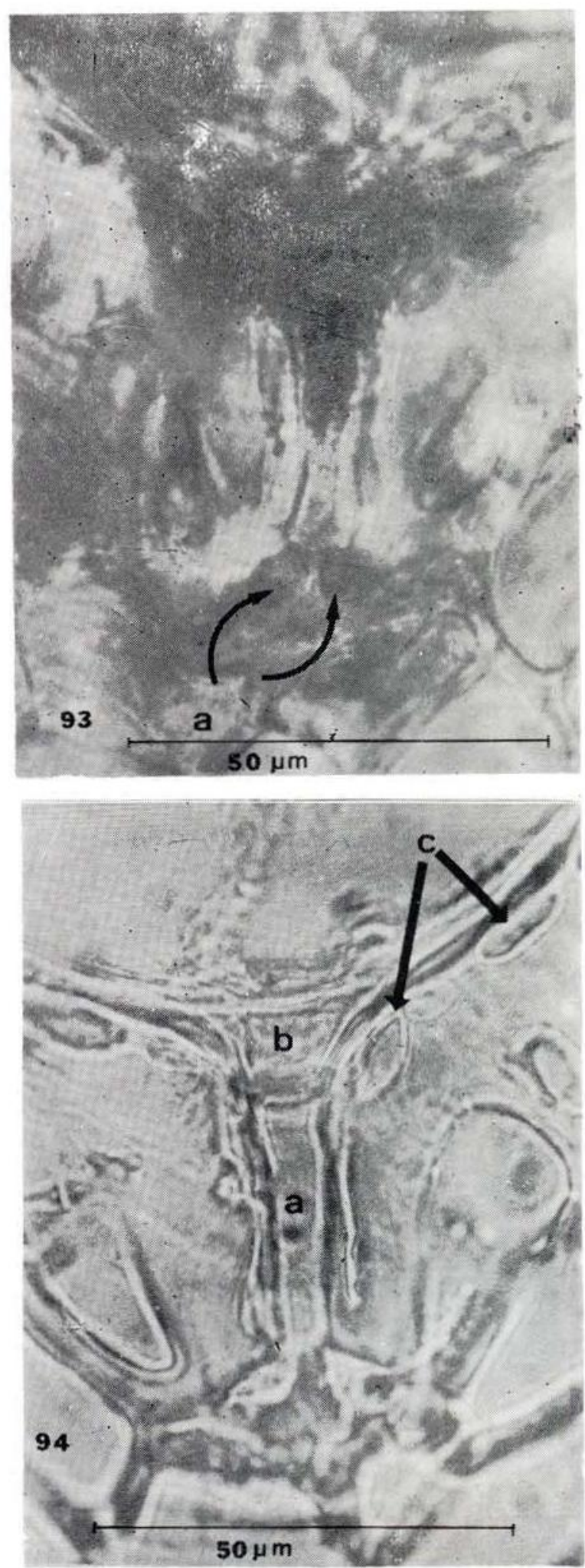

Fig. 93-94 - Ananas ananassoides. Corte transversal de uma escama. Meio-meio. Fig. 93 - Epiderme inferior. a - células basais. Fig. 94 - Epiderme superior. a - célula do pedícuio, b - célula do escudo e c - céluias epidérmicas. 
O corte transversal das células-guardas do estômato em sua região mediana (Fig. 86) mostra que estas se apoiam nas células subsidiárias (uma em cada), sendo que apenas uma estreita faixa de células subsidiárias atinge a superfície externa do estômato separando-o das células epidérmicas laterais ou vizinhas. Logo abaixo das células-guardas, as células subsidiárias apresentam um diâmetro maior, estreitando-se inferiormente e prolongando-se de tal forma que ficam mais ou menos no mesmo nível das células epidérmicas internamente (Fig. 86 e 88).

As células epidérmicas que se dispõem verticalmente na cavidade sobre o estômato atravessam a câmara subestomática de tal forma, que quase chegam a obstrui-la. Em corte transversal mediano das células-guardas, a última célula epidérmica que atravessa a câmara subestomática aparece no meio das duas células subsidiárias, o corpo silicoso que porta parece aflorar na superfície da célula o que dá a impressão de que existe uma célula epidérmica com corpo silicoso obstruindo a entrada da câmara subestomática (Fig. 86,88 e 89). O corte longitudinal de uma célula-guarda (Fig. 87) mostra que esta tem a forma de um arco e o lume da célula que é estreito na região mediana alarga-se na região polar. As células epidérmicas que forram a câmara subestomática quase se unem inferiormente (Fig. 89).

ESCAMAS: VISTA FRONTAL E CORTE TRANSVERSAL

As escamas em vista frontal mostram-se com uma forma irregular quando localizadas na base (Fig. 90 e 91) e com a forma arredondada geralmente regular, quando localizadas no meio e ápice.

As escamas do meio e ápice têm as células, próximas do centro e as da periferia do escudo, grandes e em forma de pentágono ou hexágono (Fig. 92), enquanto nas escamas da base, somente as células localizadas próximas ao centro do escudo é que têm característica semelharite, as células da periferia geralmente são alongadas (Fig. 90 e 91).
Em corte transversal as escamas apresentam: duas células basais, cujas paredes periclinais internas são espessadas (Fig. 93), uma célula constituindo o pedículo (Fig. 94) e células do escudo.

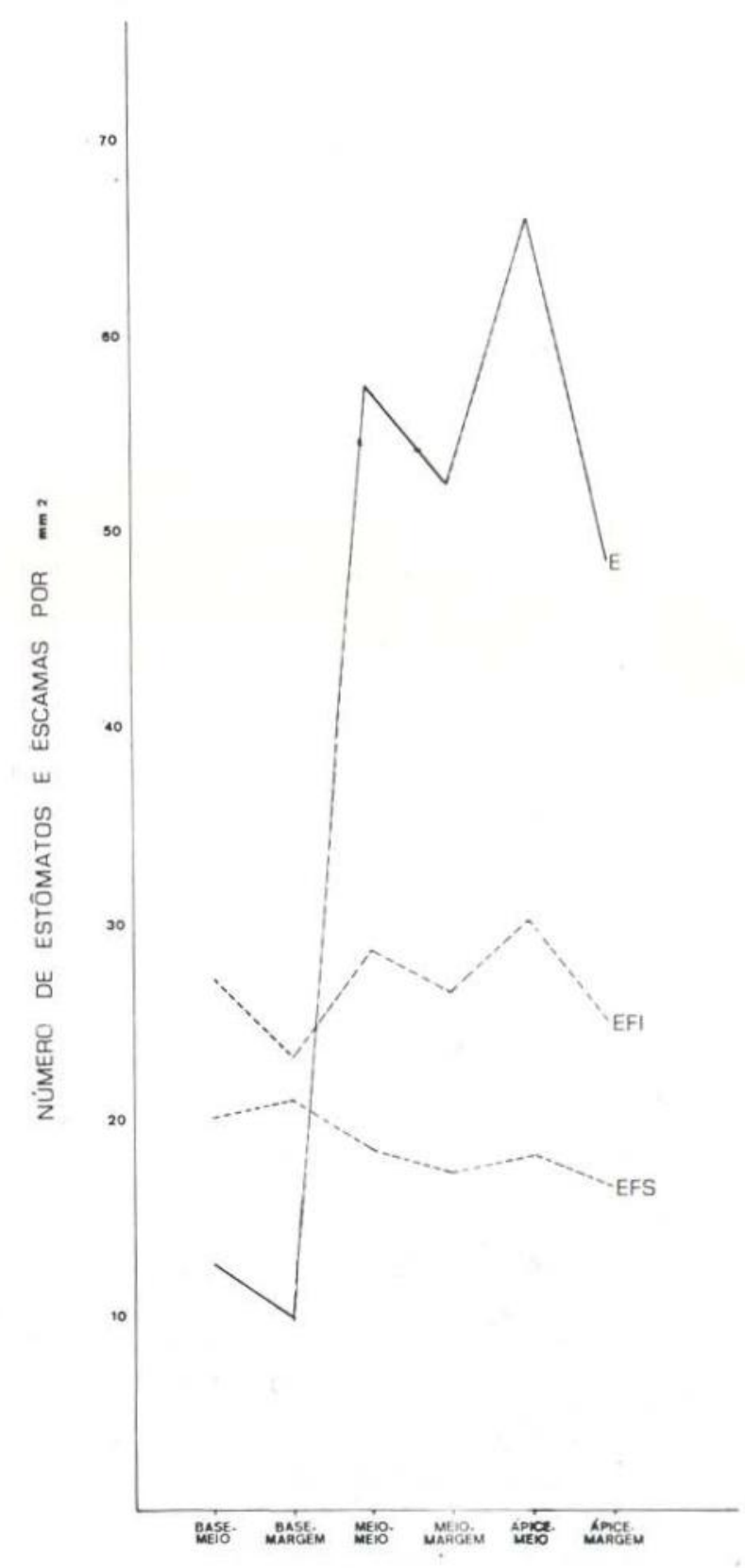

Gráfico 3 - Ananas ananassoides. E - média do número de estômatos, EFS - média do número de escamas da face superior e EFI - média do número de escamas da face inferior. 


\section{Streptocalyx poeppigii Beer}

\section{EPIDERME SUPERIOR}

REGIÃO MEIO-MEIO:

A epiderme superior da folha de Streptocalyx poeppigii é provida de escamas (Fig. 95).

As células epidérmicas encontram-se dis. postas em fileiras regulares, com o cixo maior da célula disposto no mesmo sentido do comprimento da folha. A forma das células varia entre quadrada, retangular e irregular, principalmente as duas primeiras; suas paredes anticlinais são muito onduladas, lembrando um quebra-cabeça. No lume de cada célula, observa-se um corpo silicoso esférico-espinhoso (como na base-margem, figura 96).

As escamas estão distribuídas em filas irregulares, variando o espaço entre duas filas vizinhas e o espaço entre duas escamas consecutivas na mesma fila (Fig. 95). A média do número de escamas nesta região é de 13,4 escamas por milímetro quadrado

OUTRAS REGIÕES:

O aspecto é semelhante a meio-meio (Fig. 97), variando quanto ao número de escamas, sendo que na base-meio este número foi maior e, no ápice, um pouco maior que no meio (Gráfico 4).

Na região onde emerge um acúleo, geralmente há alteração na forma (irregulares), tamanho (pequenas) e disposição (confluindo para o acúleo) das células.

\section{EPIDERME INFERIOR}

\section{REGIÃO MEIO-MEIO:}

A epiderme inferior da folha de Streptocalyx poeppigii é provida de escamas e estômatos (Fig. 98).

As células epidérmicas têm características semelhantes às da epiderme superior, apresentando uma tendência a serem mais alongadas.

As escamas e estômatos estão distribuídos, juntamente com parte das células epidérmicas, em faixas intercaladas por faixas de apenas células epidérmicas (Fig. 98).
As faixas de escamas, estômatos e células epidérmicas têm um aspecto regular, às vezes aiterando a largura da faixa — algumas são mais estreitas. Geralmente as escamas situam-se perifèricamente na faixa e os estômatos centralmente (Fig. 98).

Os estômatos e escamas encontram-se próximos e devido ao escudo da escama ser grande, ele cobre os estômatos, que estão em volta (Fig. 99).

A média do número de escamas nesta região é de 30,7 por milímetro quadrado e a mesma relação para estômatos é de 58,9.

OUTRAS REGIÕES:

No meio-margem, ápice-meio (Fig. 100) e ápice-margem as características da epiderme são similares a meio-meio. Na base-meio e base-margem (Fig. 101), as faixas anteriormente citadas estão praticamente reduzidas a fileiras mais ou menos regulares. Nas regiões onde as escamas encontram-se muito próximas, as células epidérmicas tendem à forma quadrada (Fig. 102); mesmo ocorrendo em fileiras, os escudos das escamas cobrem os estômatos (Fig. 103).

A variação do número de escamas não é muito grande em comparação com meio-meio: 31,4 escamas por milímetro quadrado na base-meio e cerca de 27 escamas por milímetro quadrado no ápice-meio. A variação do número de estômatos é grande: 1,9 estômatos por milímetro quadrado na base-meio e 74,5 no ápice-meio.

\section{REgIÃo MEIO-MEIO DA FOLHA EM CORTE} TRANSVERSAL (Fig. 104)

A epiderme superior da folha de Streptocalyx poeppigii é composta de uma camada de células pequenas, geralmente pentagonais, cujas paredes periclinal interna e anticlinais são espessas e a periclinal externa delgada. O lume da célula possui um corpo silicoso esférico. A epiderme superior, tal como a inferior, apresenta muitas reentrâncias.

A camada hipodérmica tem células hexagonais, de paredes muito espessas e lume pe- 
queno. As paredes anticlinais destas células tendem a ser alongadas. A camada infericr a esta é constituída de células pentagonais, he. xagoriais ou irregulares, arredondadas, paredes espessas mas com lume grande. Segue-se
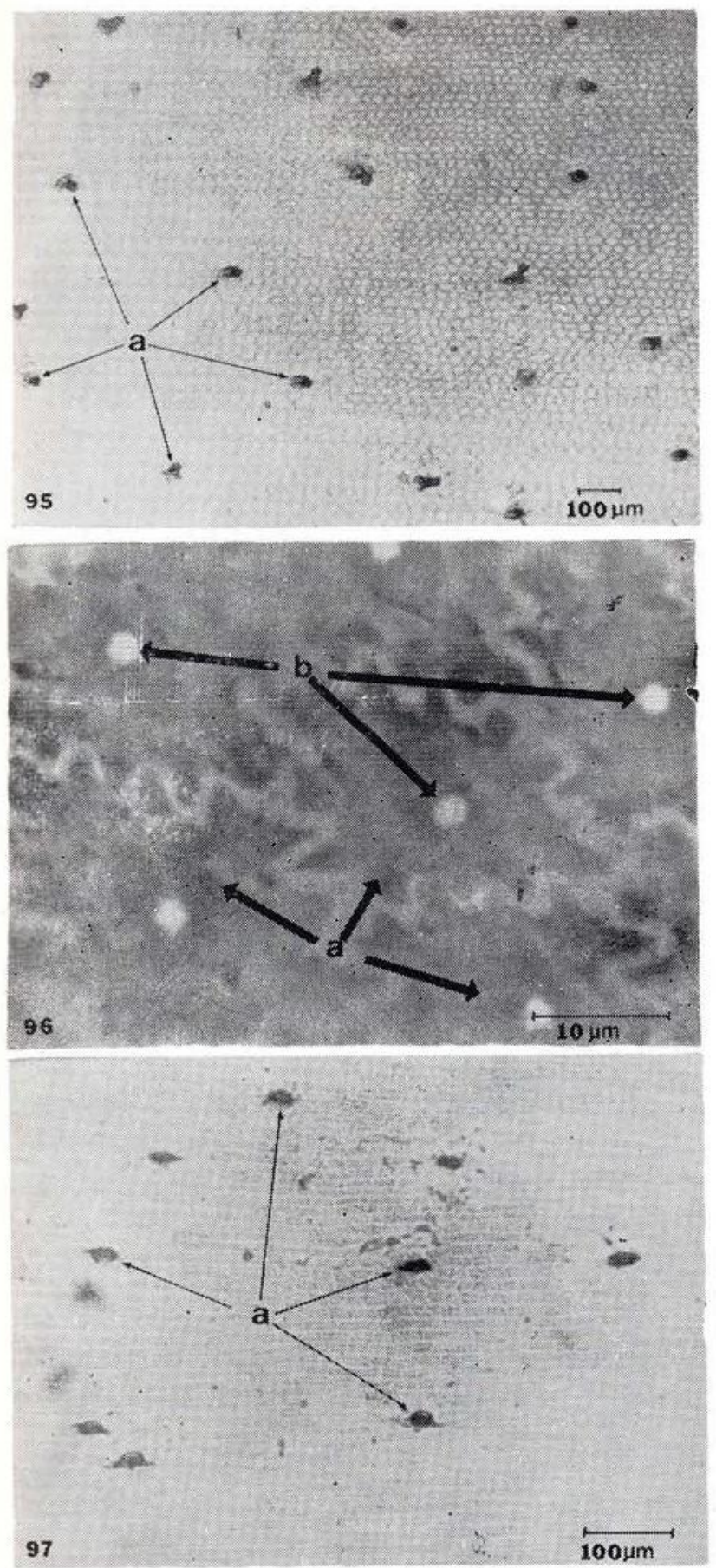

Fig. 95-97 - Streptocalyx poeppigii. Epiderme superior em vista frontal. Fig. 95 - Meio-meio. a escamas. Fig. 96 - Base-margem. a - células epidérmicas $\mathrm{e} \cdot \mathrm{b}-$ corpos silicosos. Fig. $97-$ Meic-margem. a - escamas. a esta o parênquima aqüífero composto de três camadas celulares, sendo as células grandes, arredondadas, de paredes finas; o tama. nho das células aumentando em direção ao meio do mesófilo.
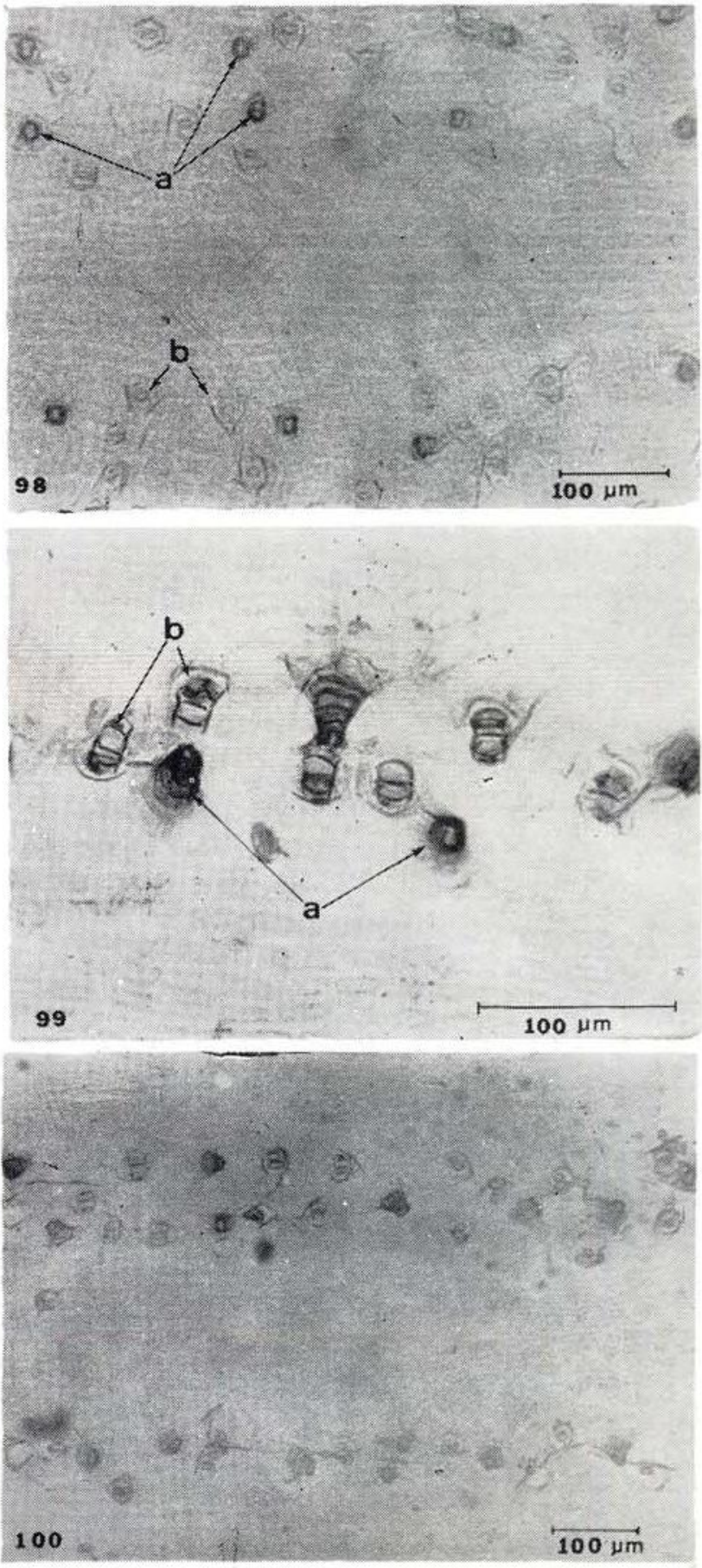

Fig. 98-100 - Streptocalyx poeppigii. Epiderme inferior em vista frontal. Fig. 98 - Meio-meio. a escamas e b - estômatos. Fig. 99 - Meio-meio. a - escamas e b - estômatos. Fig. $100-$ Ápice-meio. 
Inferiormente temos o parênquima ciorofiliano propriamente dito, que ocupa todo o espaço inferior do mesófilo junto com a hipoderme e epiderme inferiores. No meio deste pa-
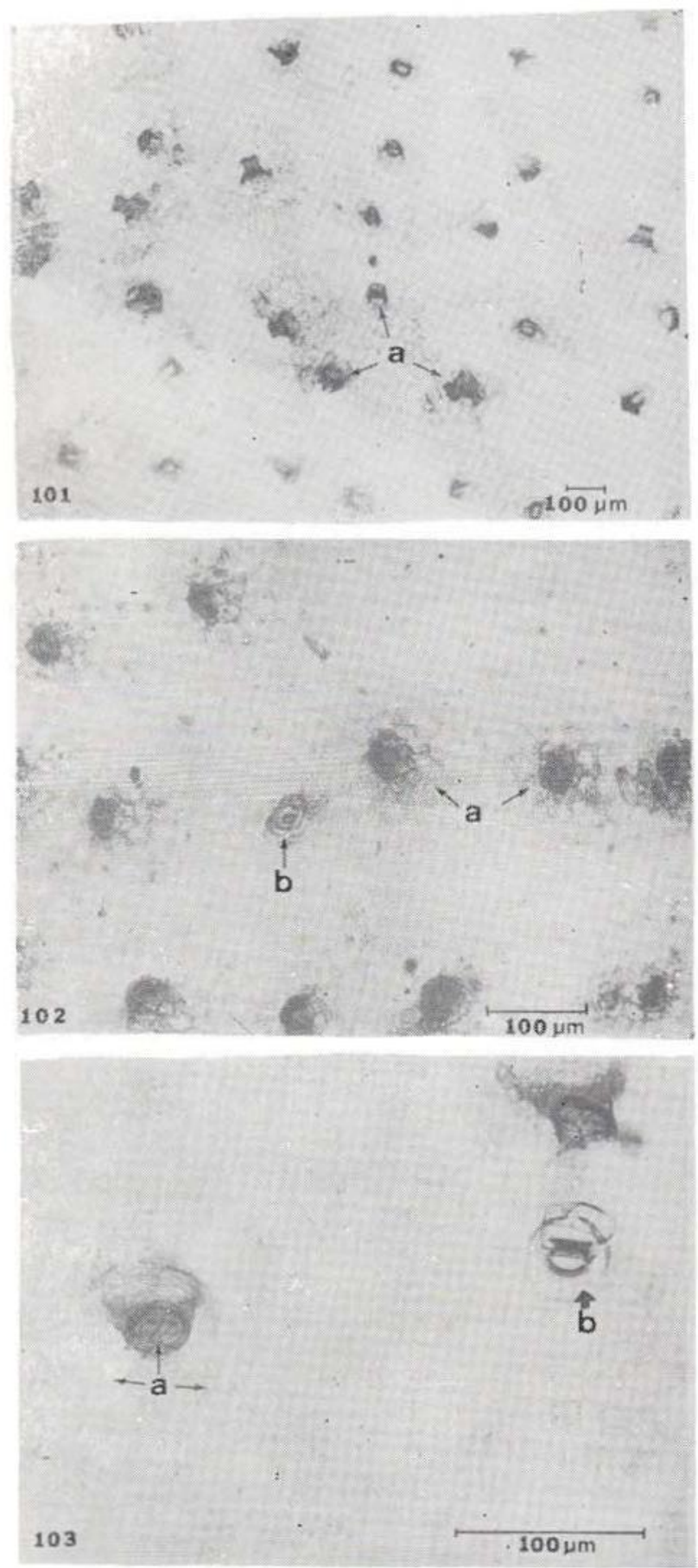

Fig. 101-103 - Streptocalyx poeppigii. Epiderme inferior em vista frontal. Fig. 101 - Base-margem. a - escamas. Fig. 102 - Base-margem. a - escamas e b - estômatos. Fig. 103 - Base-margem. $\mathrm{a}$ - escama e b - estômato. rênquima, estão distribuídos os feixes vasculares e o parênquima braciforme.

As células do parênquima clorofiliano propriamente dito são arredondadas, mais ou menos uniformes quanto à forma e tamanho; possuem paredes delgadas. Os cloroplastos concentram-se mais na parte superior deste parênquima.

O parênquima braciforme, também clorofilado, distribui-se entre os feixes, num nivel inferior a estes. Suas células têm cerca de cinco a seis braços e paredes delgadas (Fig. 105). Nas regiões onde ocorrem estômatos, este parênquima se prolonga em direção aqueles.

Os feixes vasculares estão distribuídos paralelamente uns aos outros, apresentando vários graus de complexidade. Cada feixe principal é envolvido por fibras esclerenquimáticas, que se dispõem em forma de um oito. As fibras, que diretamente envolvem os vasos, têm a forma hexagonal, são pequenas ou grandes, paredes espessas com pontuações e !ume pequeno (inclusive as que separam o xilema do floema). Aquelas localizadas nas extremidades superior e inferior das fibras anteriormente citadas possuem as mesmas características destas, mas apresentam o lume maior (Fig. 106). O protoxilema dispõe-se superior e centralmente em relação aos elementos de vasos do metaxilema. Ambos são envolvidos por parênquima. Os feixes menos desenvolvidos diferem dos anteriores quanto ao grau de reforço de fibras e quanto ao número de elementos de vasos e de elementos de tubos crivados.

A hipoderme e epiderme inferiores apresentam um aspecto semelhante às correspondentes superiores.

\section{REGIÃo MEIO-MARGEM DA FOLHA EM CORTE TRANSVERSAL (Fig. 107)}

Esta região diferencia-se da anterior, meio-meio, no seguinte aspecto - as células da região correspondente ao parênquima aqüífero e parênquima braciforme são substituídas por células do parênquima clorofiliano. 

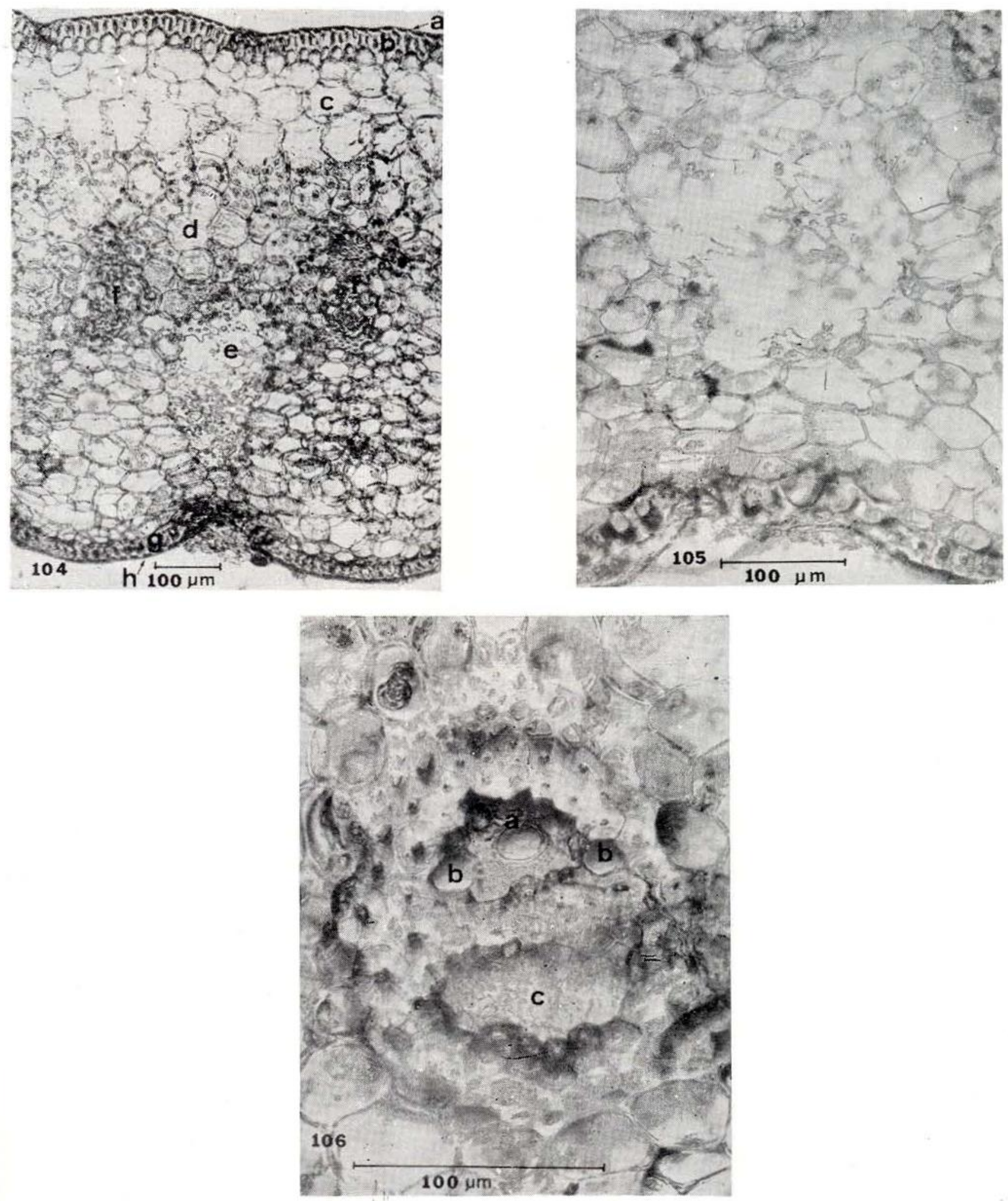

Fig. 104-106 - Streptocalyx poeppigii. Corte transversal da região meio-meio. Fig. 104 - Aspecto geral. a - epiderme superior, b - hipoderme, c - parênquima aquífero, d - parênquima clorofiliano, e - parênquima braciforme, $\mathrm{f}-$ feixes vasculares, $\mathrm{g}-$ hipoderme e $\mathrm{h}-$ epiderme inferior. Fig. $105-$ Parênquima braciforme. Fig. 106 - Feixe vascular principal. a - elementos de vasos do protoxilema, b - elementos de vasos do metaxilema e c - floema. 

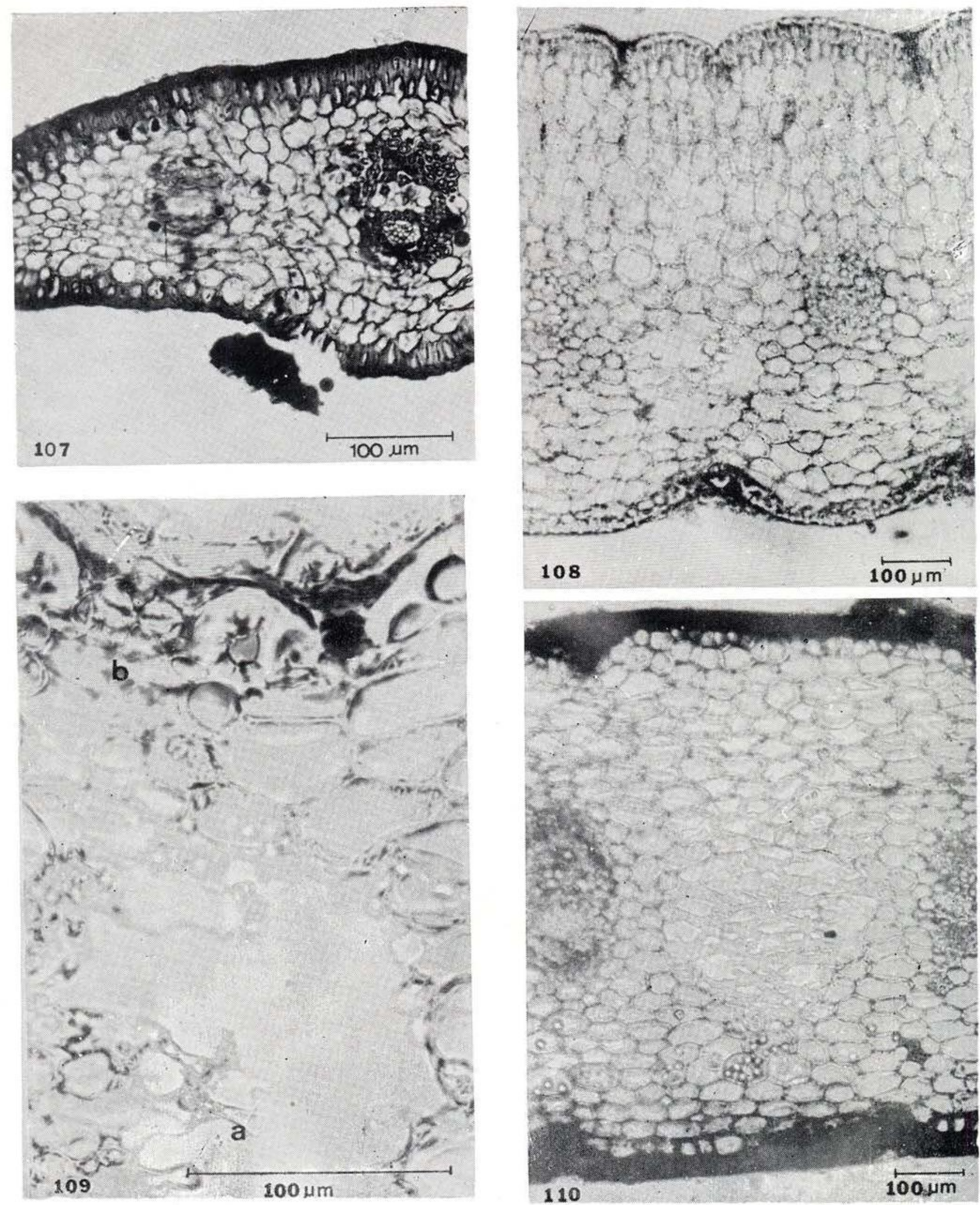

Fig. 107-110 - Streptocalyx poepnigii. Fig. 107 - Corte transversal da região meio-margem. Fig. 108 - Corte transversal da região ápice-meio. Fig. 108 - Corte transversal da região ápice-meio. a - parênquima braciforme prolongando-se até b - câmara subestomática. Fig. 110 - Corte transversal da região base-meio. 
REGIÃo ÁPICE-MEIO DA FOLHA EM CORTE TRANSVERSAL (Fig. 108)

$\mathrm{Na}$ região ápice-meio, encontramos as seguintes variações estruturais em relação a meio-meio:

- a camada abaixo da hipoderme supericr apresenta células hexagonais, bem regulares. com paredes espessas e lume grande;

- o parênquima aqüífero tem suas células clorofiladas e com um número maior de camadas.

O parênquima braciforme, tal qual na região meio-meio, prolonga-se até a região da câmara subestomática (Fig. 109).
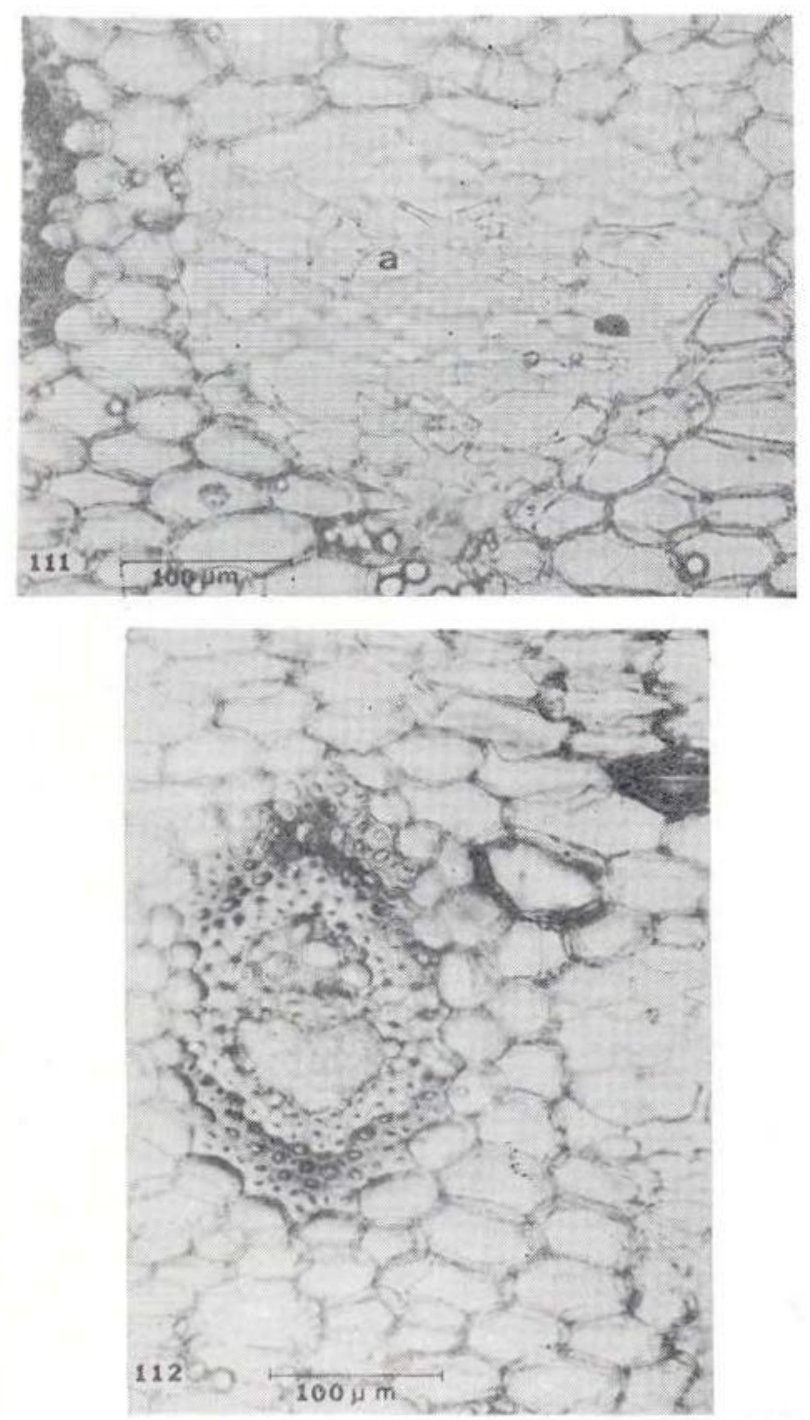

Fig. 111-112 - Streptocalyx poeppigii. Corte transversal da região base-meio. Fig. 111 - Parênquima braciforme. Fig. 112 - Feixe vascular.
REGIÃo BASE-MEIo DA FOLHA EM CORTE TRANSVERSAL (Fig. 110)

$\mathrm{Na}$ base, as camadas de células abaixo da hipoderme superior e acima da hipoderme inferior apresentam paredes bem espessas.

As células correspondentes às do parênquima aqüífero e clorofiliano da regiăo meio-meio têm características semelhantes no que se refere à forma e ao tamanho, conseqüentemente distingue-se um do outro - pela posição na folha. No interior dessas, não ocorre a presença de cloroplastos, mas em compensação estão cheias de grãos de amido.

O espaço ocupado pelo parênquima braciforme é maior e encontra-se mais ou menos ao mesmo nivel dos feixes vasculares (Fig. 110 e 111).

Nos feixes vasculares, observa-se maior esclerificação das fibras que envolvem o feixe vascular (Fig. 112).

Muito esparsadamente verifica-se a ocorrência de ninhos de fibras esclerenquimáticas imersos no parênquima.

\section{ESTÔMATOS: VISTA FRONTAL E CORTE TRANSVERSAL}

Uma observação da epiderme inferior de Streptocalyx poeppigii permite verificar que os estômatos se encontram dentro de peque-

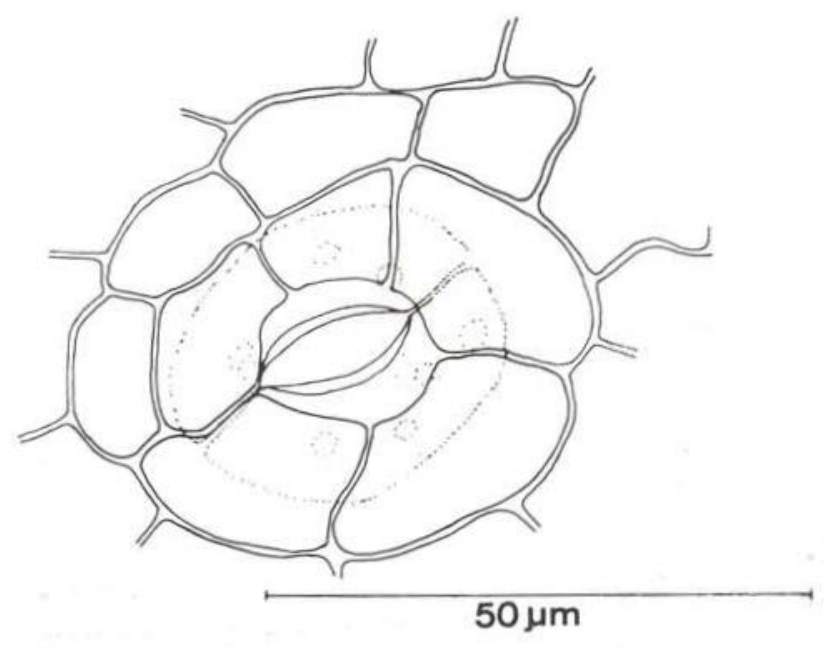

Fig. 113 - Streptocalyx poeppigii. Estômato em vista frontal. a - células-guardas, b - células vi zinhas e c - células epidérmicas. 
nas cavidades na epiderme. Na periferia destas cavidades, encontram-se, no plano horizontal, várias células epidérmicas circundando a cavidade e cerca de quatro ou cinco células, dispostas duas ou três lateralmente e duas nos polos, em posição vertical, forrando a referida cavidade (Fig. 113). Em corte transversal, observa-se que as células subsidiárias projetam-se abaixo das células-guardas e as suas faces periclinais externas são muito reduzidas, o que dificulta a observação das mesmas
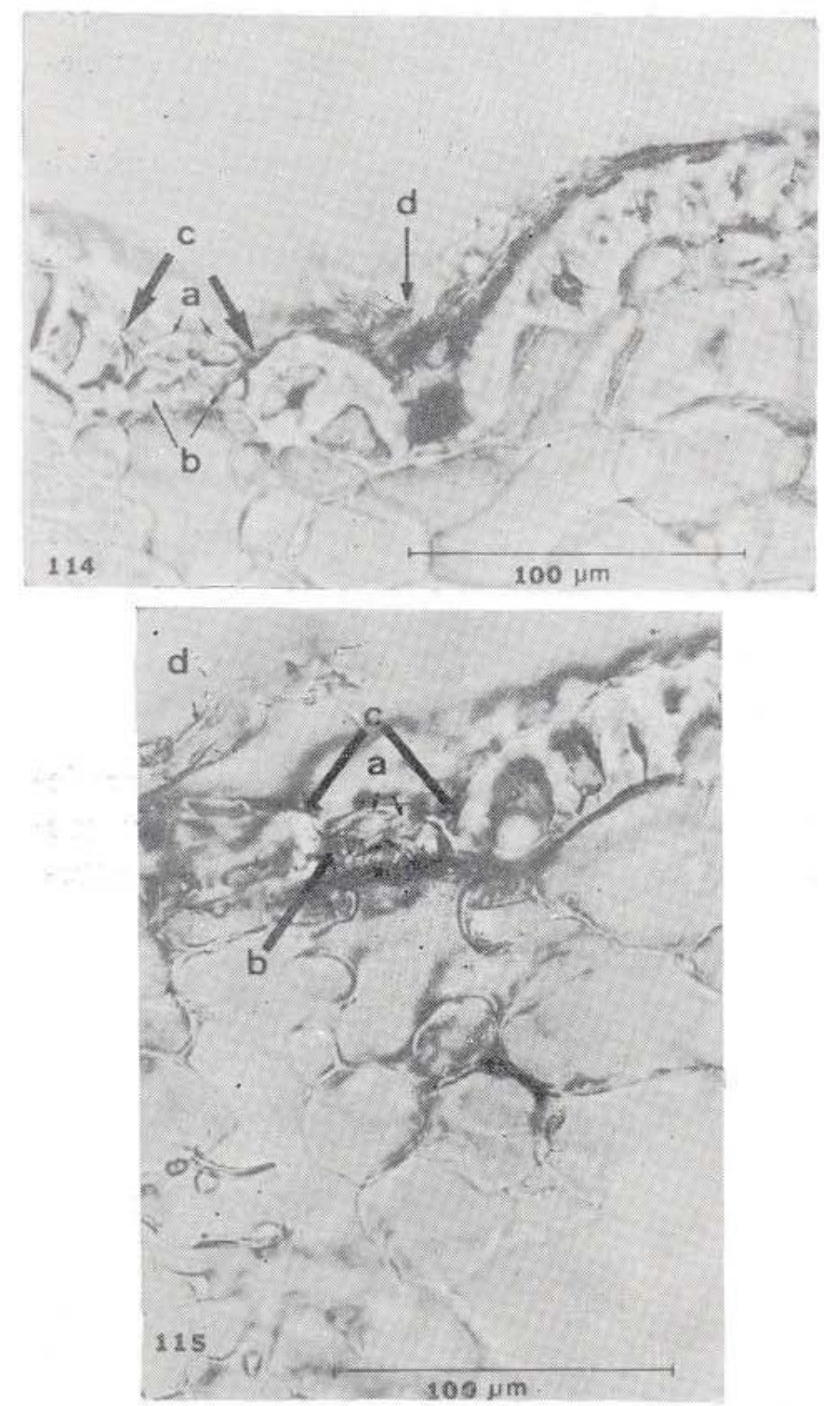

Fig. 114-115 - Streptocalyx poeppigii. Corte transversal da região meio-meio. Fig. 114 - Corte transversal das células-guardas do estômato em sua região mediana. a - células-guarcias, b - células subsidiárias, c - células vizinhas e d - escama. Fig. 115 - Corte transversal das células-guardas do estômato em sua região polar. a - células-guardas, b - célula subsidiária, c - célula vizinha e d - escudo de uma escama. em vista frontal da epiderme. As células que revestem a câmara subestomática, que se encontram embaixo das células-guardas, emitem projeções no sentido de obstruir a entrada da câmara subestomática (Fig. 109 e 114).

O corte transversal na região mediana das células-guardas mostra que nesta o lume é estreito; o mesmo corte na região polar mostra-o um pouco mais amplo (Fig. 115).
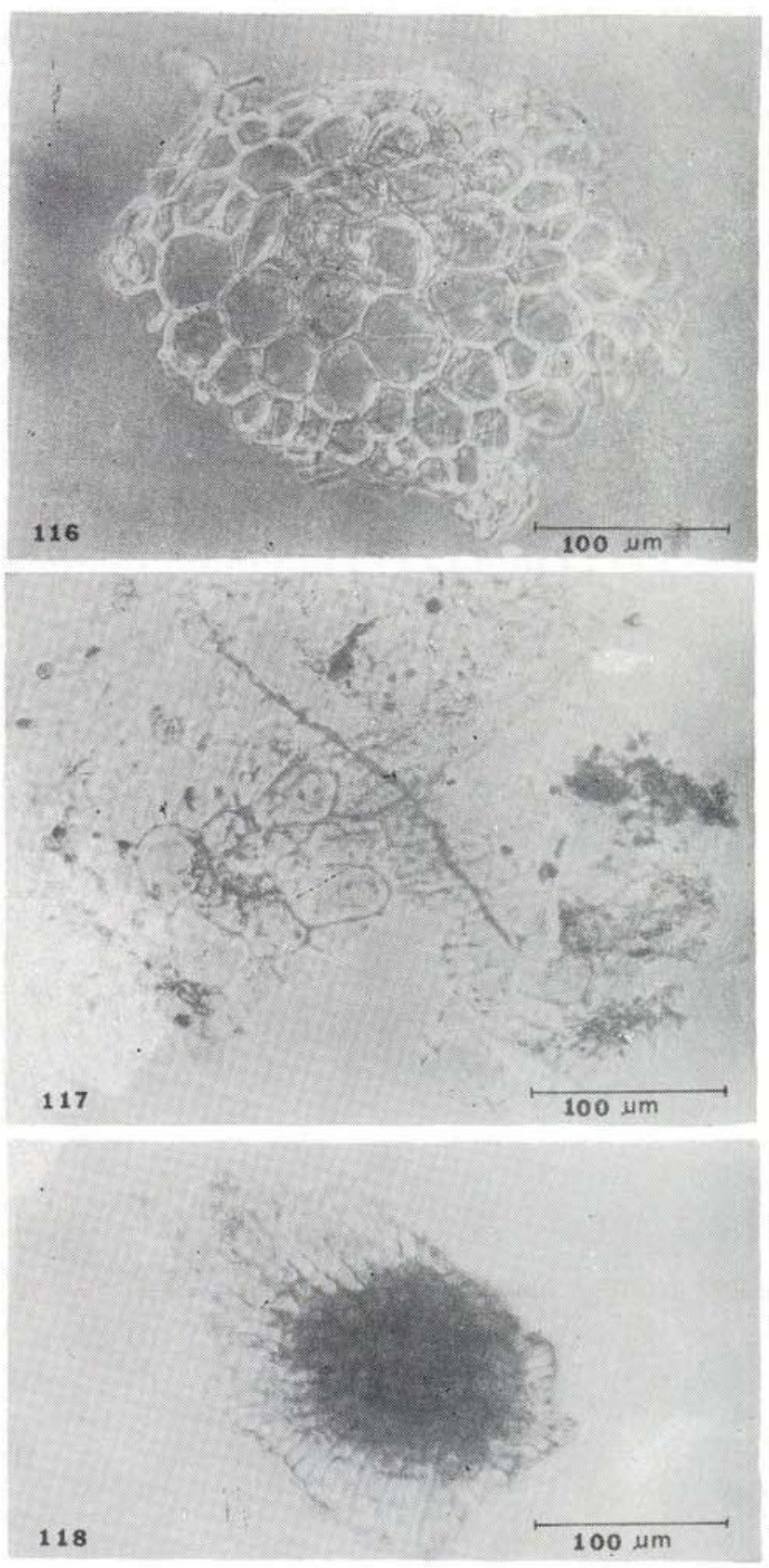

Fig. 116-118 - Streptocalyx poeppigii. Escamas em vista frontal. Epiderme superior. Fig. 116 - Ápice-meio. Fig. 117 - Meio-meio. Fig. 118 - Base-meio. 
ESCAMAS: VISTA FRONTAL E CORTE TRANSVERSAL

As escamas, em vista frontal, mostram-se geralmente, com uma forma arredondada, regular ou irregular. As células localizadas no centro do escudo são grandes, quadradas, pentagonais ou hexagonais; podendo ocorrer duas, ou mais camadas com estas características. A medida que as células se aproximam da periferia, tomam a forma retangular alongada e com paredes mais delgadas (Fig. 116, $117 \mathrm{e}$ 118).
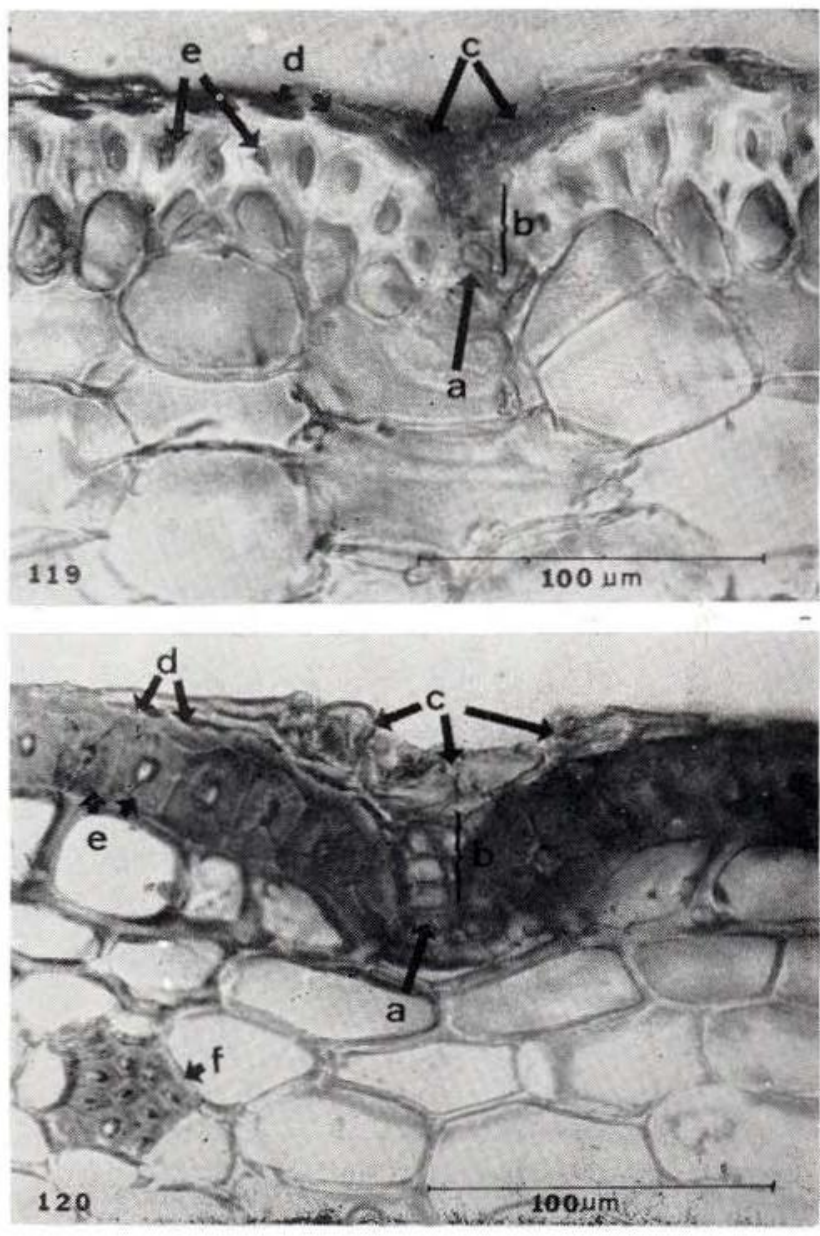

Fig. 119-120 - Streptocalyx poeppigii. Corte transversal de uma escama. Fig. 119 - Meio-meio. Epiderme superior, a - célula basal, b - células do pedículo, c - células do escudo, d - células da epiderme e e - células hipodérmicas. Fig. $120-$ Base-meio. Epiderme inferior. a - célula basal, b - øélulas do pedículo, c - células do escudo, d - células epidérmicas, e - células hipodérmicas e $\hat{i}$ - ninho de fibras esclerenquimáticas.
Em corte transversal, as escamas da epiderme superior apresentam: uma ou duas células basais, quatro ou mais células do pediculo e as células do escudo. As da epiderme inferior diferenciam-se destas por apresentarem as células do pedículo mais largas (Fig. 119 e 120).

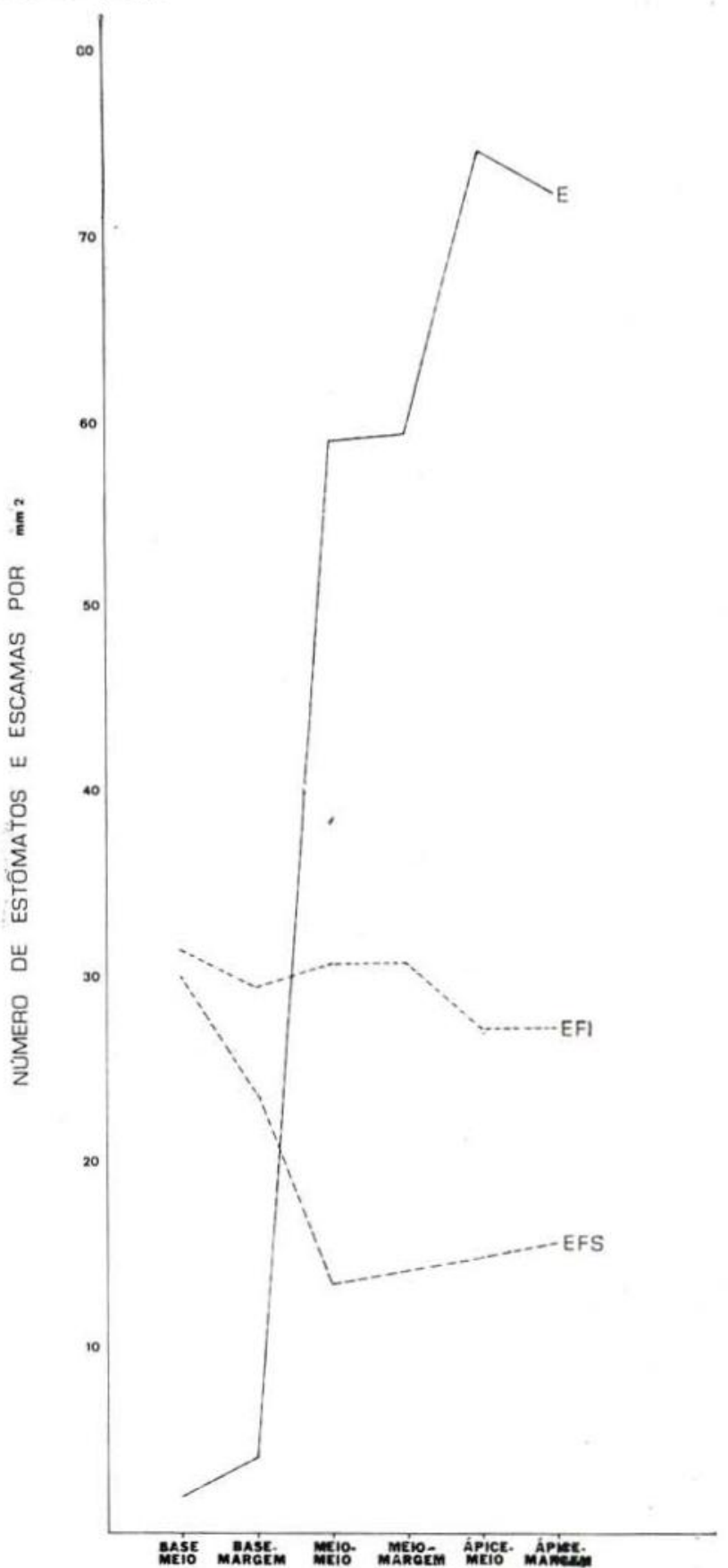

Gráfico 4 - Streptocalyx poeppigii. $\mathrm{E}-$ média do número de estômatos, EFS - média do número de escamas da face superior e EFI - média do número de escamas da face inferior. 


\section{Tillandsia adpressiflora $\mathrm{Mez}$}

EPIDERME SUPERIOR

\section{REGIÃO MEIO-MEIO:}

A epiderme superior da folha de Tillandsia adpressiflora é provida de escamas (Fig. 121).

As células epidérmicas em vista frontal aparecem dispostas em fileiras longitudinais com o eixo maior da célula no mesmo sentido do comprimento da folha, a forma das células é retangular, geralmente retangular alongada, muito raramente irregular (Fig. 121). Suas paredes anticlinais são muito onduladas, iembrando um quebra-cabeça. No lume de cada uma, pode-se observar a presença de um pequeno corpo silicoso esférico-espinhoso.

As escamas dispõem-se muito próximas uma das outras, seus escudos se sobrepõem, formando uma verdadeira capa sobre a epiderme. A média do número de escamas nesta região é de 29 escamas por milímetro quadrado de superfície epidérmica.

\section{OUTRAS REGIÕES:}

As regiões: meio-margem, ápice-meio, ápice-margem e base-meio apresentam características semelhantes a meio-meio quanto à disposição das escamas, forma e parede das células e presença de corpo silicoso (Fig. 122). $\mathrm{Na}$ base-margem o tamanho das células é menor e a forma muito irregular (Fig. 123).

O número médio de escamas da epiderme superior atingiu um ponto alto na região base-meio, o mesmo não ocorrendo na base-margem (Fig. 123 e 124). No ápice este número foi um pouco maior que no meio (Gráfico 5).

\section{EPIDERME INFERIOR}

REGIÃo MEIO-MEIO:

A epiderme inferior da folha de Tillandsia adpressiflora é provida de escamas e estômatos.

As células epidérmicas apresentam as mesmas características das células da epiderme superior quanto à disposição, forma, tamanho, parede e conteúdo.
As escamas e estômatos não ocorrem em faixas nem em filas distintas, distribuem-se muito irregularmente (Fig. 125) levando em conta os padrões de distribuição em fila ou em faixa encontrados de um modo geral, mesmo assim nota-se que os estômatos estão cobertos pelos escudos das escamas.

O número médio de escamas desta região por milímetro quadrado de superfície epidérmica é de 22,8 e o de estômatos é de 18,9

OUTRAS REGIÕES:

As demais regiões analisadas apresentam aspectos similares a meio-meio, sendo que na base-meio e base-margem, as células são geralmente pequenas e têm a forma muito irregular (Fig. 126). Os estômatos na base, apesar de se situarem próximos de escamas, não o estão o suficiente para serem cobertos pelos escudos das mesmas, uma vez que estes são pequenos.

A figura 127 mostra no ápice-meio estômatos cobertos pelo escudo de uma escama.

O maior número de escamas ocorre na base seguido do ápice; para estômatos a relação obtida foi de que o número destes cres. ce da base para o ápice (Gráfico 5).

\section{REGIÃo MEIO-MEIO DA FOLHA EM CORTE} TRANSVERSAL

A epiderme superior da folha, em corte transversal, mostra-se constituída de uma camada de células pequenas, pentagonais, com paredes anticlinais e periclinal interna espessas e periclinal externa delgada. O lume da célula lembra uma lente biconvexa e é portador de um pequeno corpo silicoso. Abaixo da epiderme ocorre uma camada de células pequenas, retanguiares, pentagonais ou irregulares e com paredes um pouco espessas (Fig. 128).

O parênquima aqüífero ocupa quase metade da folha, é composto de cerca de cinco camadas de células grandes, arredondadas ou poligonais, de paredes finas, às vezes ligeiramente onduladas. 


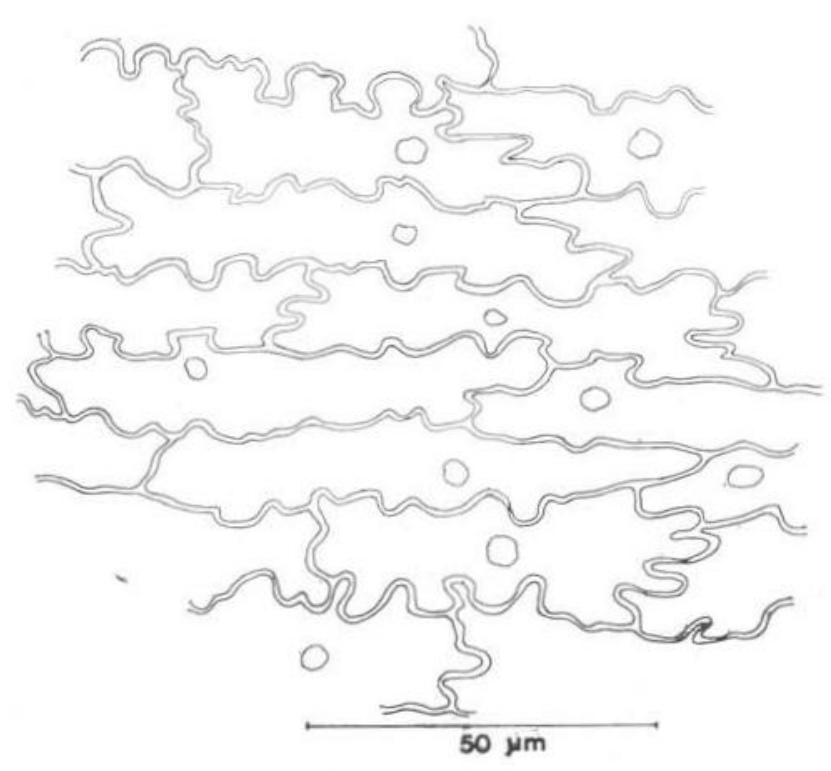

Fig. 122 - Tillandsia adpressiflora. Epiderme superior em vista frontal. Ápice-meio.

O parênquima clorofiliano possui dois tipos celulares distintos: células do parênquima clorofiliano propriamente dito e células braciformes. As primeiras dispõem-se imediatamente abaixo do parênquima aqüífero e entre os feixes vasculares, margeando-os; são células pequenas arredondadas ou alongadas, com paredes finas. As segundas ocupam o espaço entre dois feixes vasculares consecutivos, circundado pelas células do parênquima clorofiliano propriamente dito, têm cerca de quatro a seis braços e paredes finas. As lacunas que ocorrem entre as células estão em comunicação direta com a câmara subestomática, isto devido a um "canal" de células braciformes, que ligam as regiões do parênquima braciforme com as câmaras subestomáticas (Fig. 129).

Os feixes vasculares dispõem-se paralelamente uns aos outros e lado a lado ocorrem feixes de vários graus de complexidade. Um feixe mais desenvolvido (Fig. 130) mostra um reforço de fibras esclerenquimáticas ao seu redor, sendo este mais espesso na extremidade superior. Separando o xilema do floema vộ-se duas ou três camadas de fibras de diâmetro menor mas também com paredes espessas. O xilema apresenta dois ou mais ele-
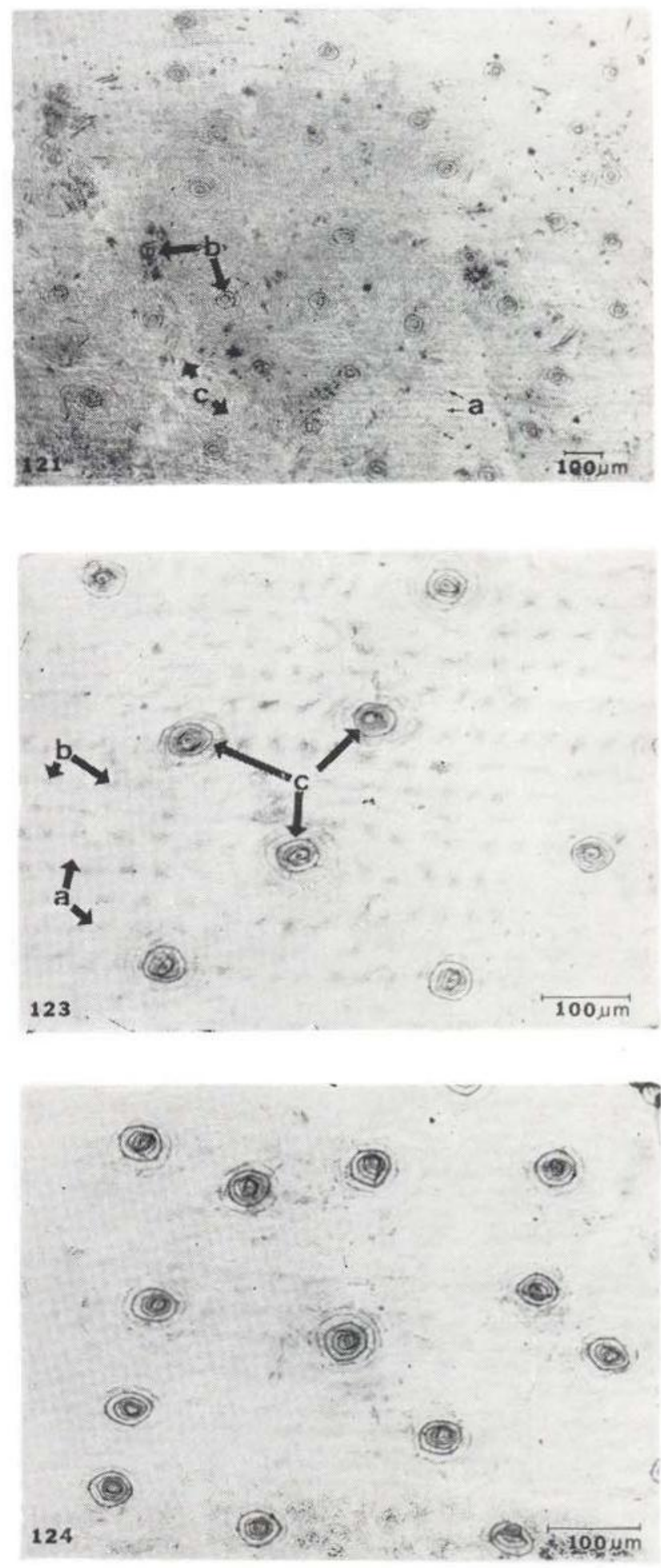

Fig. 121, 123 e 124 - Tillandsia adpressiflora. Epiderme superior em vista frontal. Fig. 121 - Meio-meio. a - células epidérmicas, b - centro do escudo e c - escudo da escama. Fig. 123 - Base-margem. a - células epidérmicas, b - corpos silicosos e c - centro do escudo das escamas. Fig. $124-$ Base-meio. Observar variação do número de escamas. 

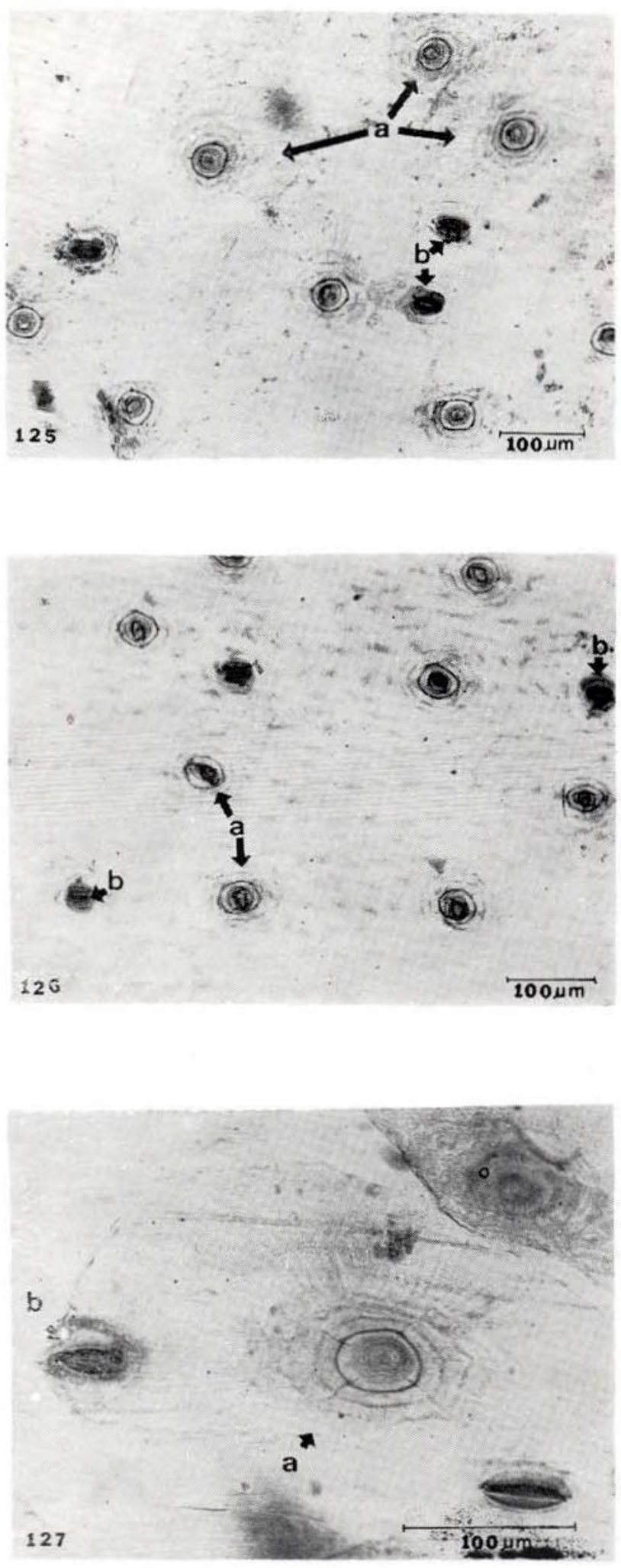

Fig. 125-127 - Tillandsia adpressiflora. Epiderme inferior em vista frontal. Fig. 125 - Meio-meio. a - escamá e b - estômatos. Fig. 126 - Base-margem. a - escamas e b - estômatos. Fig. 127 - Ápice-meio. a - escama e b - estômato. mentos de vasos do metaxilema, ocupando uma posição mediana e lateral no feixe vascular; cerca de dois elementos de vasos do protoxilema que se encontram na extremidade superior do xilema e poucas células parenquimáticas. O floema é envolvido por apenas uma camada de células parenquimáticas, fora $\mathrm{c}$ reforço de fibras.

Os feixes vasculares menos desenvolvidos diferenciam-se dos anteriores por um reforço menor de fibras esclerenquimáticas e pelo número e tamanho dos vasos, que também é menor.

Abaixo da região dos feixes vasculares e parênquima braciforme, encontra-se um parênquima com características de parênquima aqüífero constituído de quatro a cinco camadas de células interrompidas apenas pelos "canais" de células do parênquima braciforme, que se dirigem aos estômatos. Suas células são grandes e pentagonais ou hexagonais arredondadas.

A hipoderme e epiderme inferior possuem as mesmas características das correspondentes superiores com a exceção de a epiderme inferior apresentar estômatos.

Algumas fibras esclerenquimáticas podem ocorrer próximo daquelas dois feixes vasculares isoladamente.

\section{REgIÃo MEIO-MARGEM DA FOLHA EM CORTE TRANSVERSAL (Fig. 131)}

Um corte transversal desta região mostra o mesmo aspecto estrutural de meio-meio, sendo que na margem propriamente dita o parênquima braciforme fica em contato direto com os estômatos. As células do parênquima aqüífero inferior apresentam-se mais alongadas.

\section{REGIÃo ÁPICE-MEIO DA FOLHA EM CORTE TRANSVERSAL (Fig. 132)}

Difere da região meio-meio pelo fato de as células do parênquima aqüífero inferior apresentarem-se com paredes anciclinais mais alongadas. 

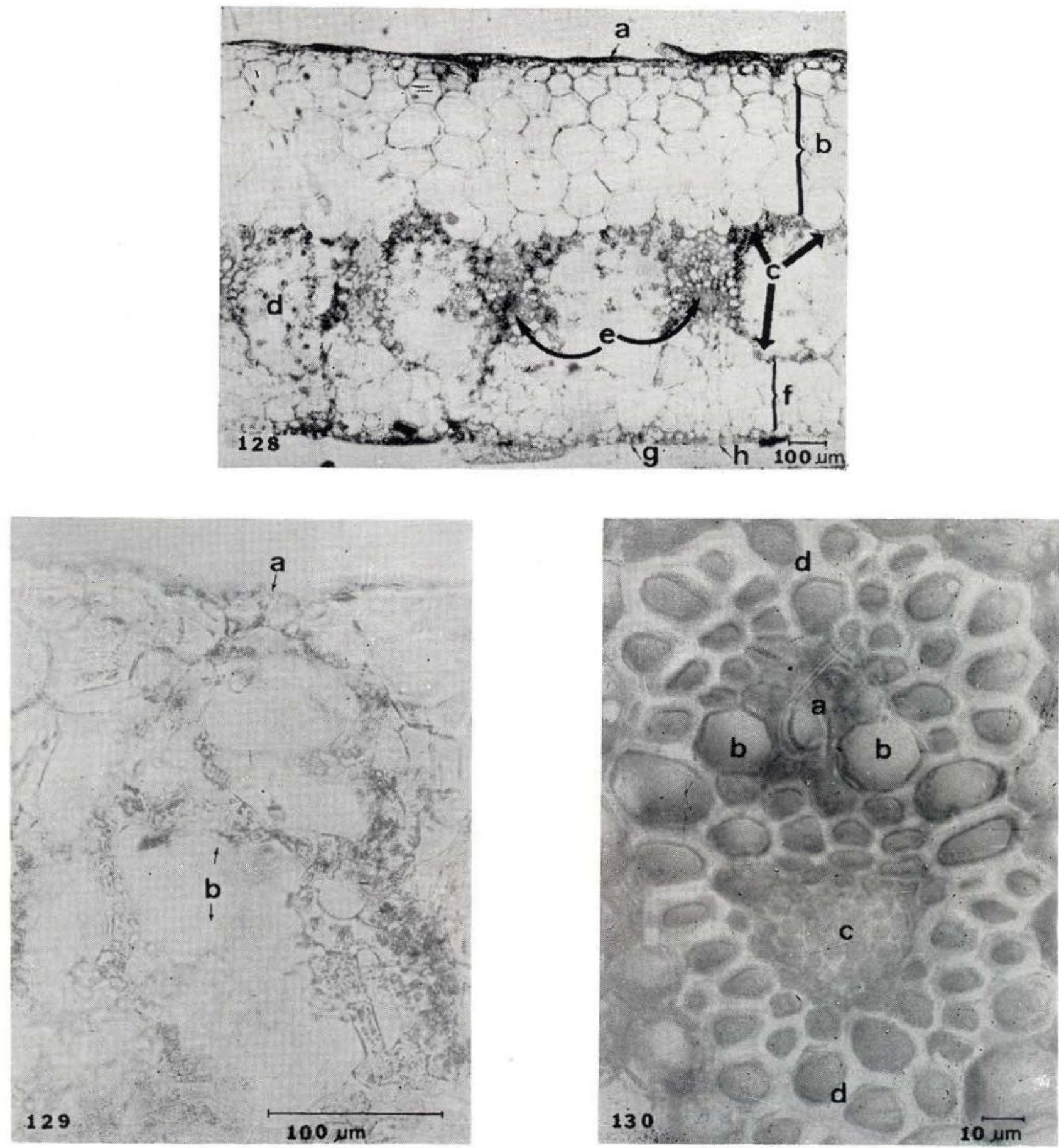

Fig. 128-130 - Tillandsia adpressiflora. Corte transversal da regiäo meio-meio. Fig. 128 - Aspecto geral. a - epiderme superior, b - parênq̣uima aquífero, c - parênquima clorofiliano, d - parênquima braciforme, e - feixes vasculares, $\mathrm{f}$ - parênquima aqüífero inferior, $\mathrm{g}$ - estômato $\mathrm{e} \mathrm{h}$ - epiderme inferior. Fig. $129 \rightarrow \mathrm{a}$ - estômato e b - "canal" de células braciformes que comunica o parênquima braciforme com a câmara subestomática. Fig. 130 - Feixe vascular principal. a - elementos de vasos do protoxilema, b - elementos de vasos do metaxilema, $\mathrm{c}$ - floema e d - reforço esclerenquimático. 

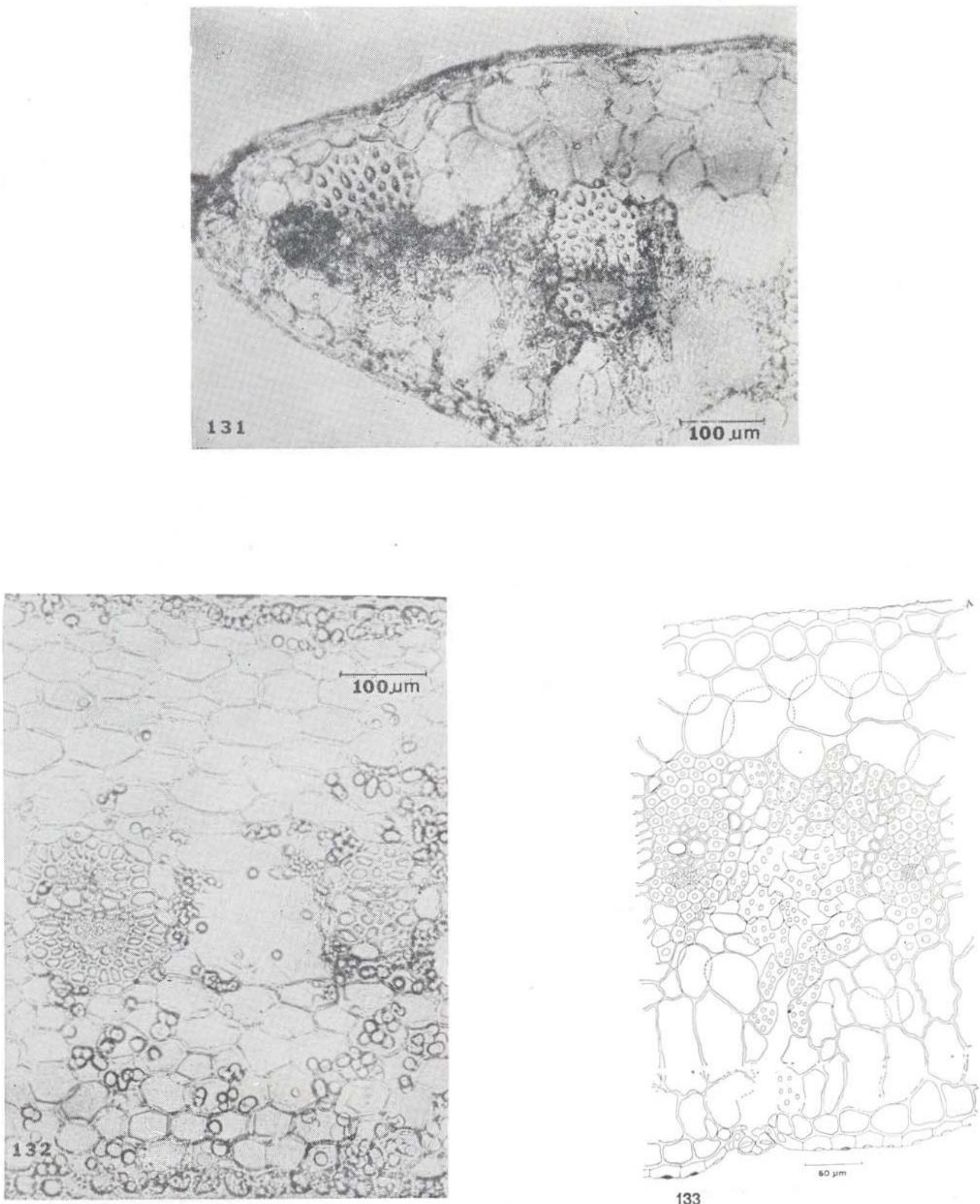

133

Fig. 131-133- Tillandsia adpressiflora. Fig. 131 - Corte transversal da região meio-margem. Aspecto geral. Fig. 132 - Corte transversal da região ápice-meio. Aspecto geral. Fig. 133 - Corte transversal da região base-meio. Aspecto geral. 

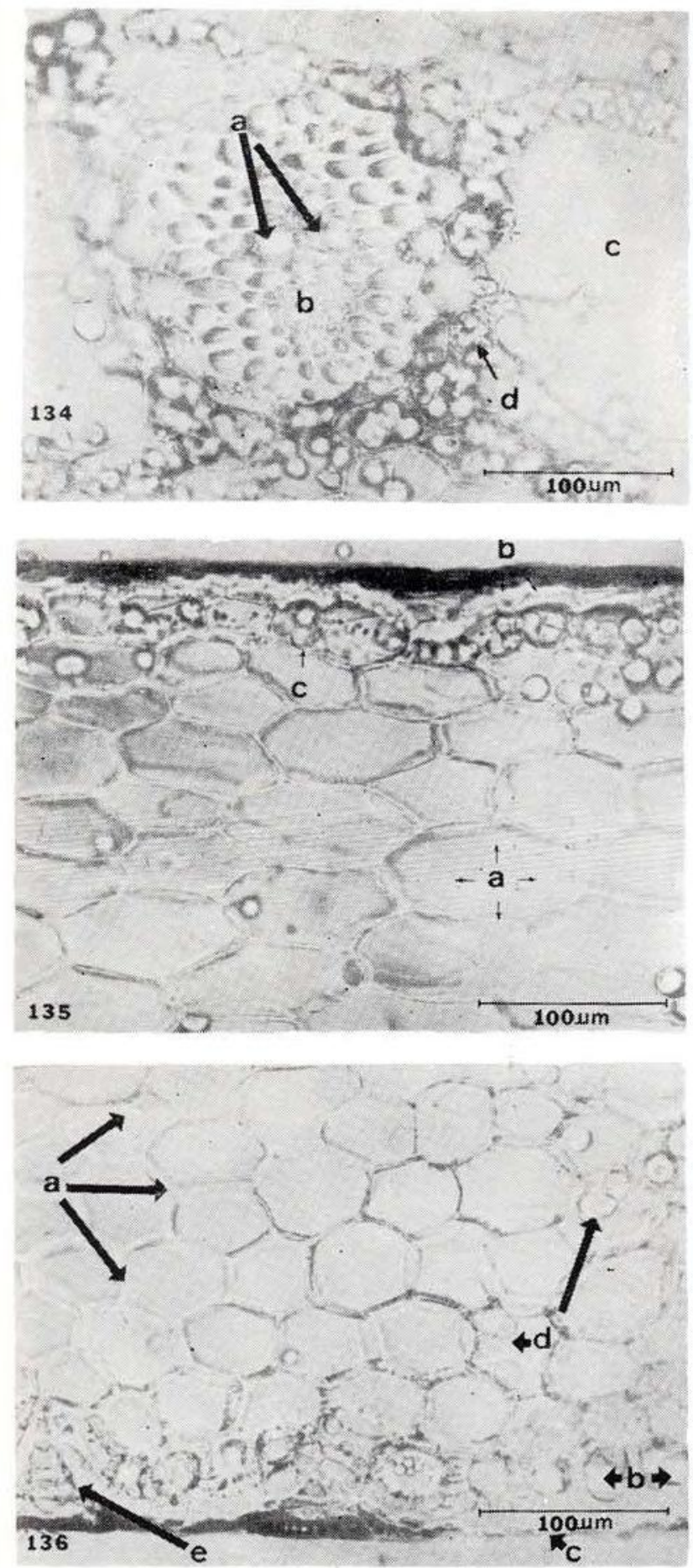

Fig. 134-136 - Tillandsia adpressiflora. Corte transversal da região base-meio. Fig. 134 - Feixe vascular. a - elementos de vasos do metaxilema, b floema, c - espaço entre células do parênquima braciforme e d - grãos de amido. Fig. 135 - a parênquima aquífero, $\mathrm{b}$ - células epidérmicas e $\mathrm{c}-$ grãos de amido. Fig. 136 - a - parênquima aqüífero, b - hipoderme, c - epiderme inferior, d - grãos de amido e e - pedículo de escama.
REGIÃo BASE-MEIO DA FOLHA EM CORTE TRANSVERSAL (Fig. 133)

O aspecto geral da estrutura da folha na base-meio é similar a meio-meio quanto à distribuição dos tecidos, diferindo nos seguintes aspectos:

- os escudos das escamas, de ambas epidermes parecem estar muito aderidos às mesmas;

- a região dos feixes vasculares ocupa uma posição mais central e estes têm o aspecto geral arredondado pelo fato do reforço esclerenquimático ser mais desenvolvido lateralmente e menos nas extremidades (Fig. 134);

- o parênquima braciforme está limitado ao espaço entre os feixes vasculares;

- as células do parênquima aqüífero superior apresentam paredes periclinais mais alongadas;
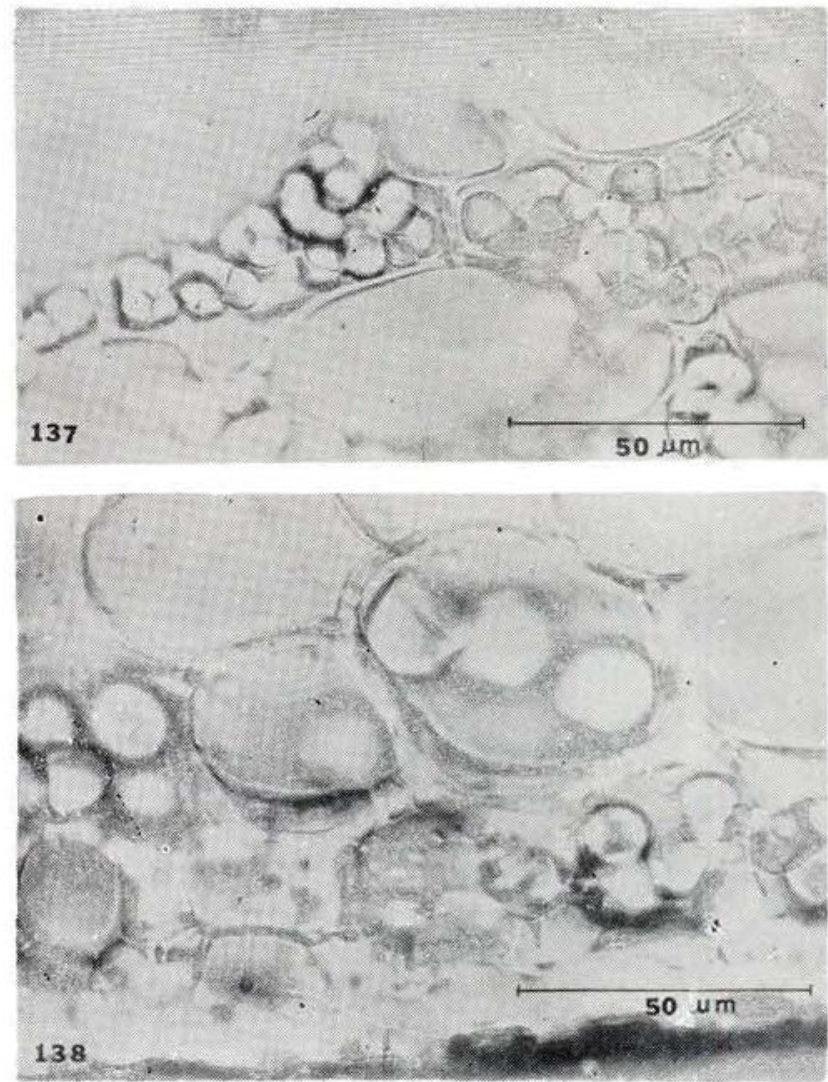

Fig. 137-138 - Tillandsia adpressiflora. Corte transversal da região base-meio. Fig. 137 - Células do parênquima braciforme repletas de grãos de amido. Fig. 138 - Hipoderme e epiderme inferior. 

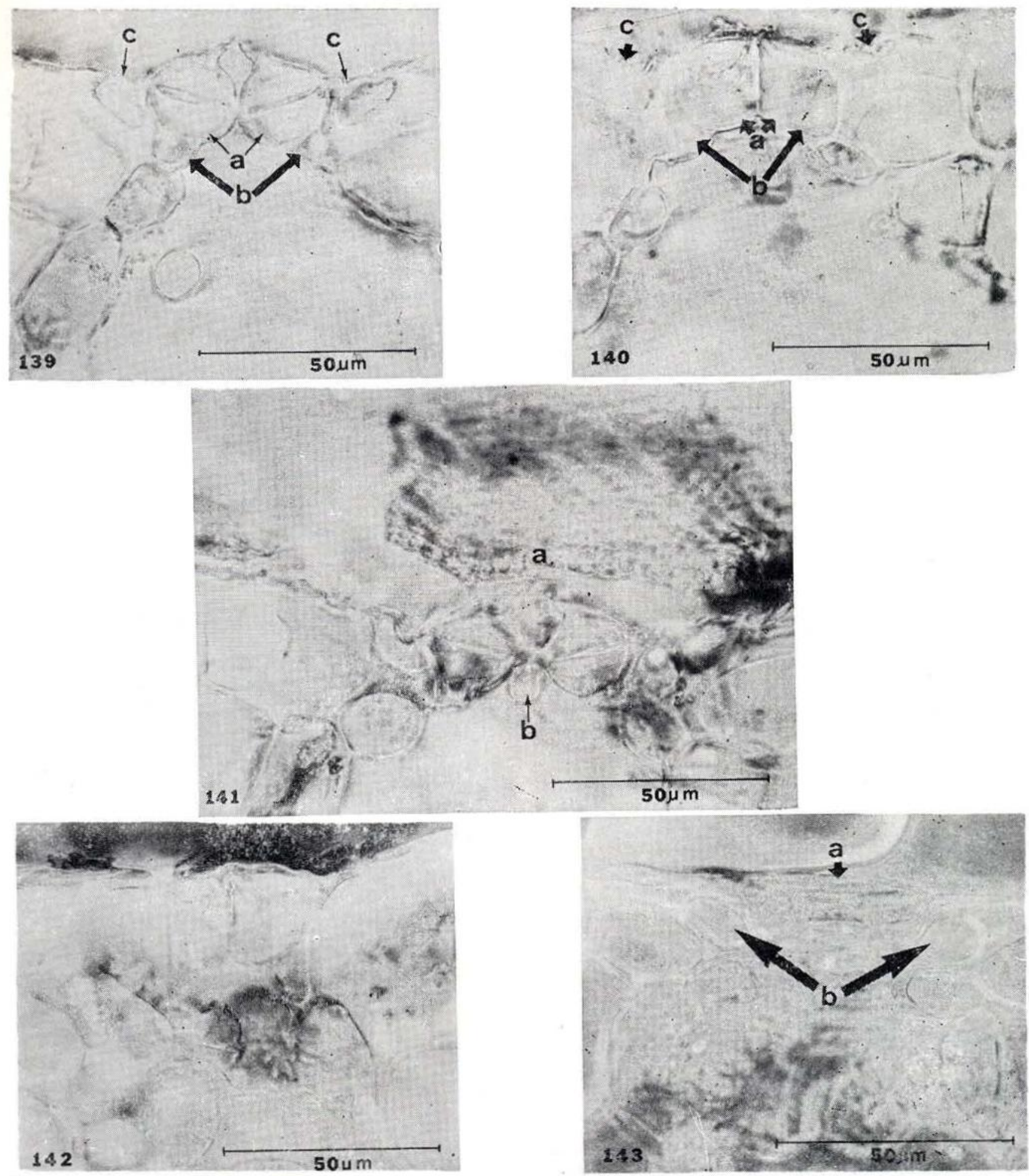

Fig. 139-143 - Tillandsia adpressiflora. Estômatos. Fig. 139 - Corte transversal das células-guardas do estômato em sua região mediana. Meio-meı. a - células-guardas, b - células subsidiárias, c - células vizinhas. Fig. 140 - Corte transversal das células-guardas do estômato em sua regiăo polar. Meio-meio. a células-guardas, b - células subsidiárias e c - células vizinhas. Fig. 141 - Corte transversal das células-guardas do estômato em sua região mediana. a - escudo de uma escama cobrindo o estômato e b projeção de célula lateral na entrada da câmara subestomática. F'ig. 142 - Corte transversal de um estômato em sua região polar. Base-meio. Fig. 143 - Corte longitudinal da célula-guarda de um estômato. $\mathrm{a}-$ célula-guarda e $\mathrm{b}$ - células vizinhas. 

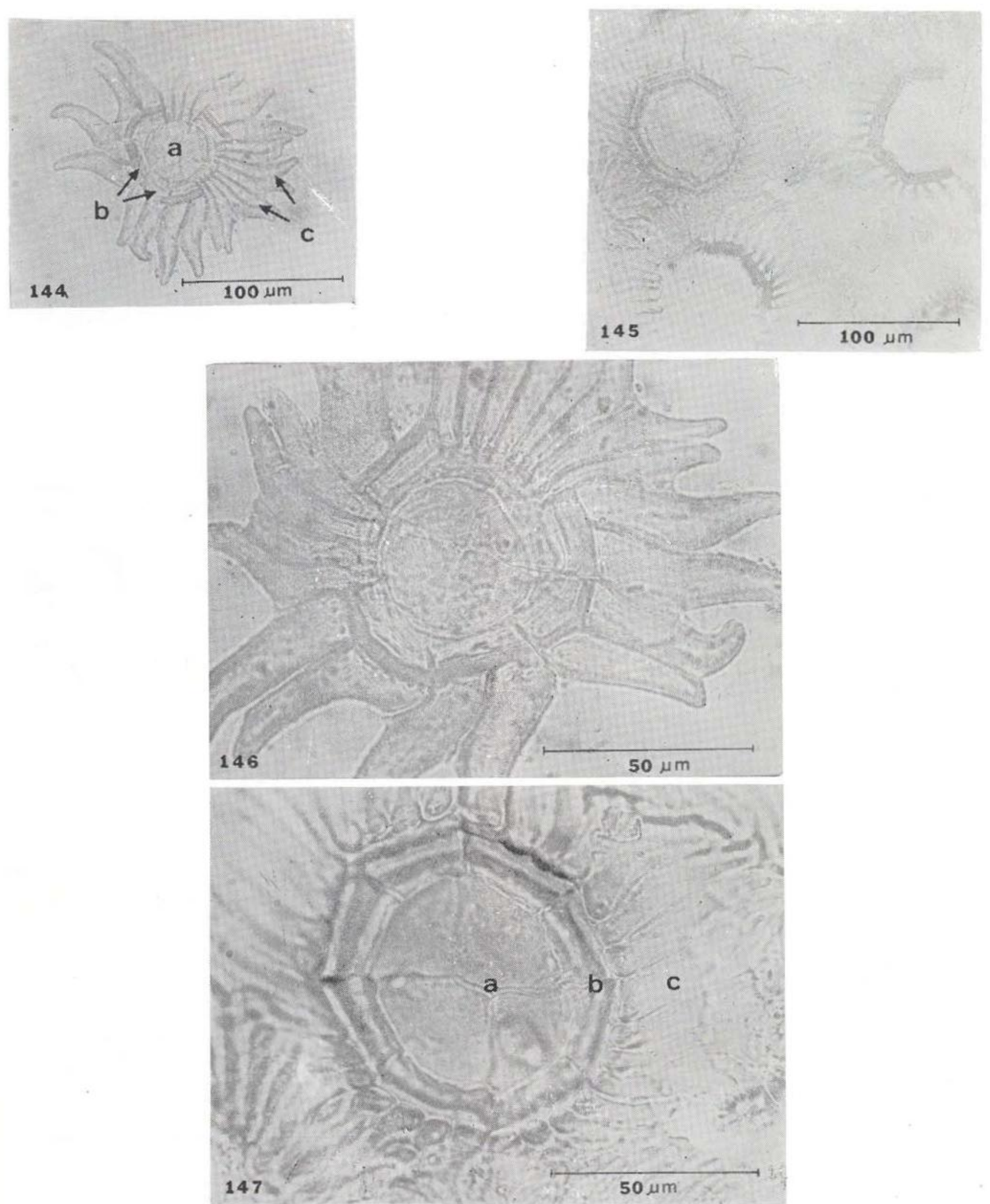

Fig. 144-147 - Tillandsia adpressiflora. Escamas da epiderme superior em vista frontal. Fig. 144 - Base-margem, a - células centrais, b - células pericentrais e c - células periféricas. Fig. $145-$ Baze-meio. Fig. 146 - Base-margem. Fig. 147 - Base-meio. a - células centrais, b - células pericentrais e c - células periféricas. 

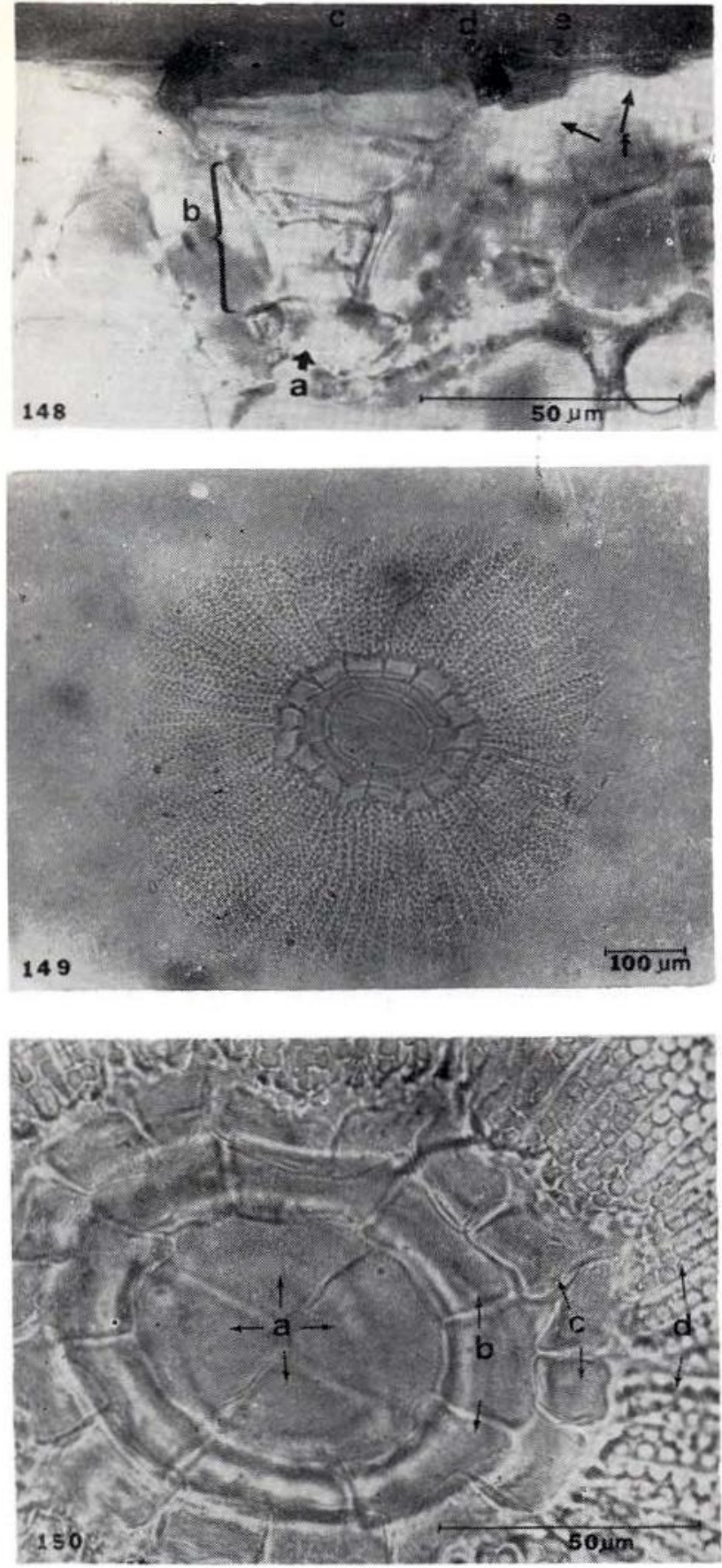

Fig. 148-150 - Tillandsia adpressiflora. Fig. 148 Corte transversal de uma escama. Base-meio. a células basal, b - células do pedículo, c - células centrais do escudo, d - células pericentrais do escudo, e - células periféricas do escudo e f - células epidérmicas. Fig. 149 - Escama da epiderme superior em vista frontal. Meio-meio. Fig. 150 - Escama da epiderme superior em vista frontal. Meio-meio. a - células centrais, b - células pericen trais, c - células subperiféricas e d - células periféricas,
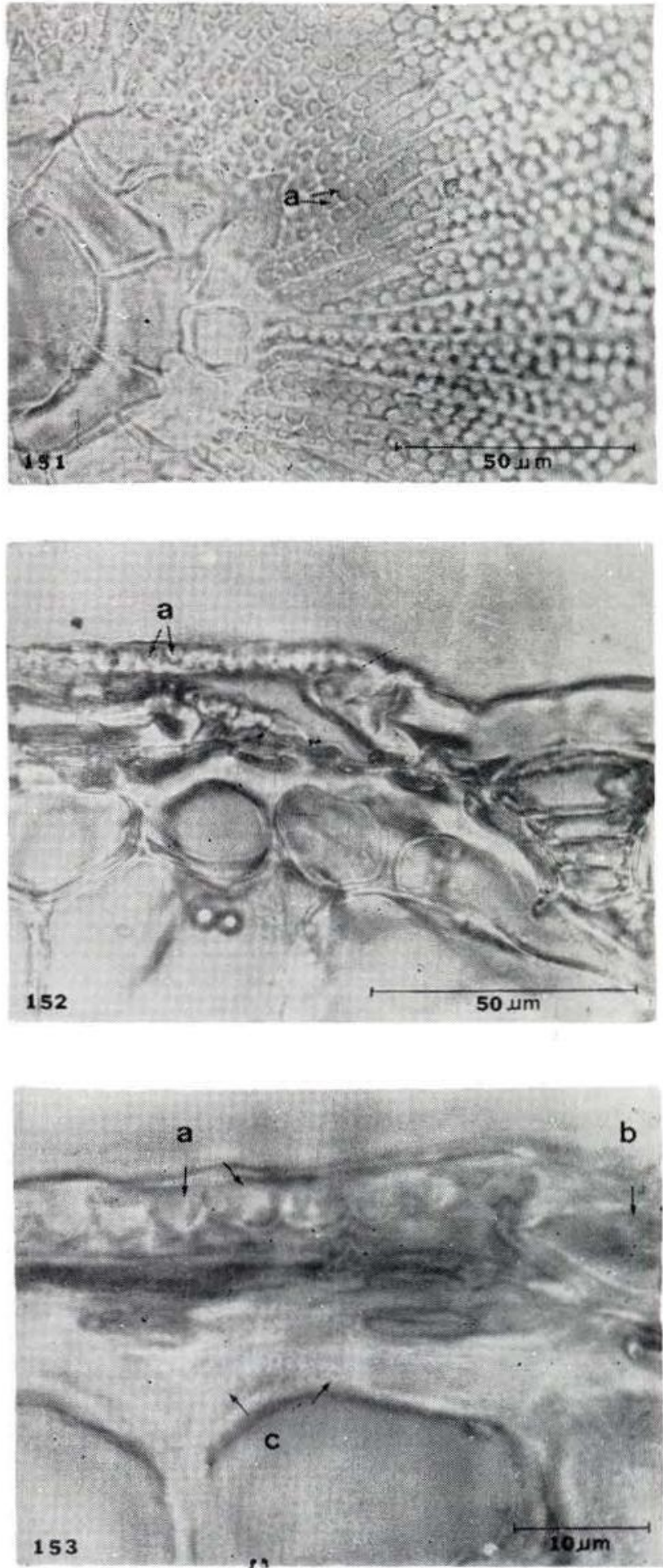

Fig. 151-153 - Tillandsia adpressiflora. Fig. - 151 - Escama da epiderme superior em vista frontal. Meio-meio. a - cavidade das células periféricas. Fig. 152 - Corte transversal de uma escama. Meio-margem. a - cavidade das células periféricas. Fig. 153 - Corte transversal de uma célula periférica. a - cavidades da célula periférica, b - cé. lula subperiférica e c - células epidérmicas. 
— tanto as células do parênquima aqüífero como as células do parênquima braciforme e até mesmo aquelas adjacentes às epidermes contêm grãos de amido (Fig. 135, 136 e 137). Estes podem ser trigeminados, geminados ou isolados (Fig. 137 e 138).

Uma hipoderme inferior com células de paredes espessas, com muitas pontuações e lume grande pode ser observada. Até mesmo nestas células hipodérmicas encontra-se grãos de amido (Fig. 138) .

\section{Estômatos: vista Frontal E CORTE}

TRANSVERSAL E LONGITUDINAL

O estômato, em vista frontal, mostra-se rodeado por cerca de cinco ou mais células vizinhas. Em corte transversal, na região mediana das células-guardas do estômato, podese constatar a presença de duas células subsidiárias laterais (Fig. 139), que se encontram numa posição quase que completamente inferior em relação às células-guardas. Estas apresentam neste corte um lume muito estreito, lembrando uma fenda transversal. Um corte nemelhante na região polar das células. guardas (Fig. 140) permite a visualização de lumes alargados principalmente na região voltada para o poro estomático. As vezes, das células que circundam a câmara subestomática, saem projeções em direção à entrada da câmara subestomática de forma a obstruí-la parcialmente (Fig. 141) .

$\mathrm{Na}$ figura 142, tem-se um corte transversal da região polar das células guardas da base

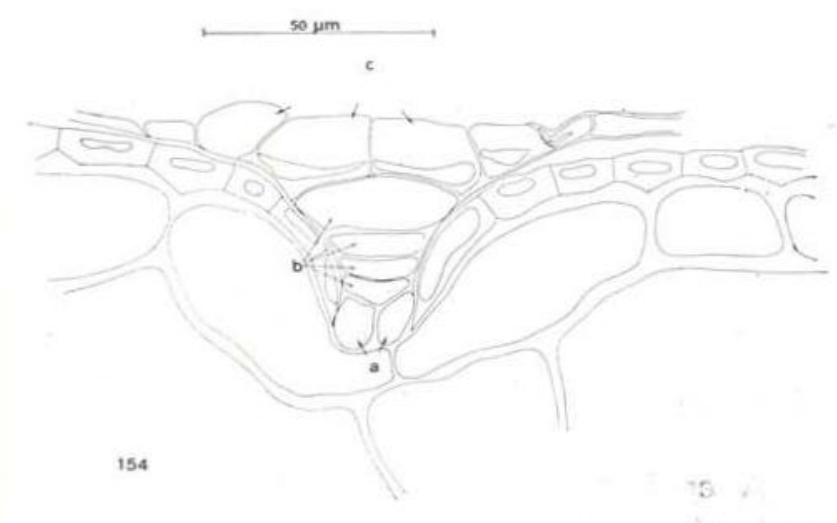

Fig. 154 - Tillandsia adpressiflora. Corte transversal de uma escama. Meio-meio. Epiderme superior. a - células basais, b - células do pedículo e c - células do escudo. da fo'ha, nele se observa uma câmara subestomática restrita e vestígios de escudos de escamas sobre as células-guardas.

Num corte longitudinal da célula-guarda, próximo à parede lateral interna, pode-se verifıcar o quanto se alarga o lume da célula na região polar (Fig. 143).

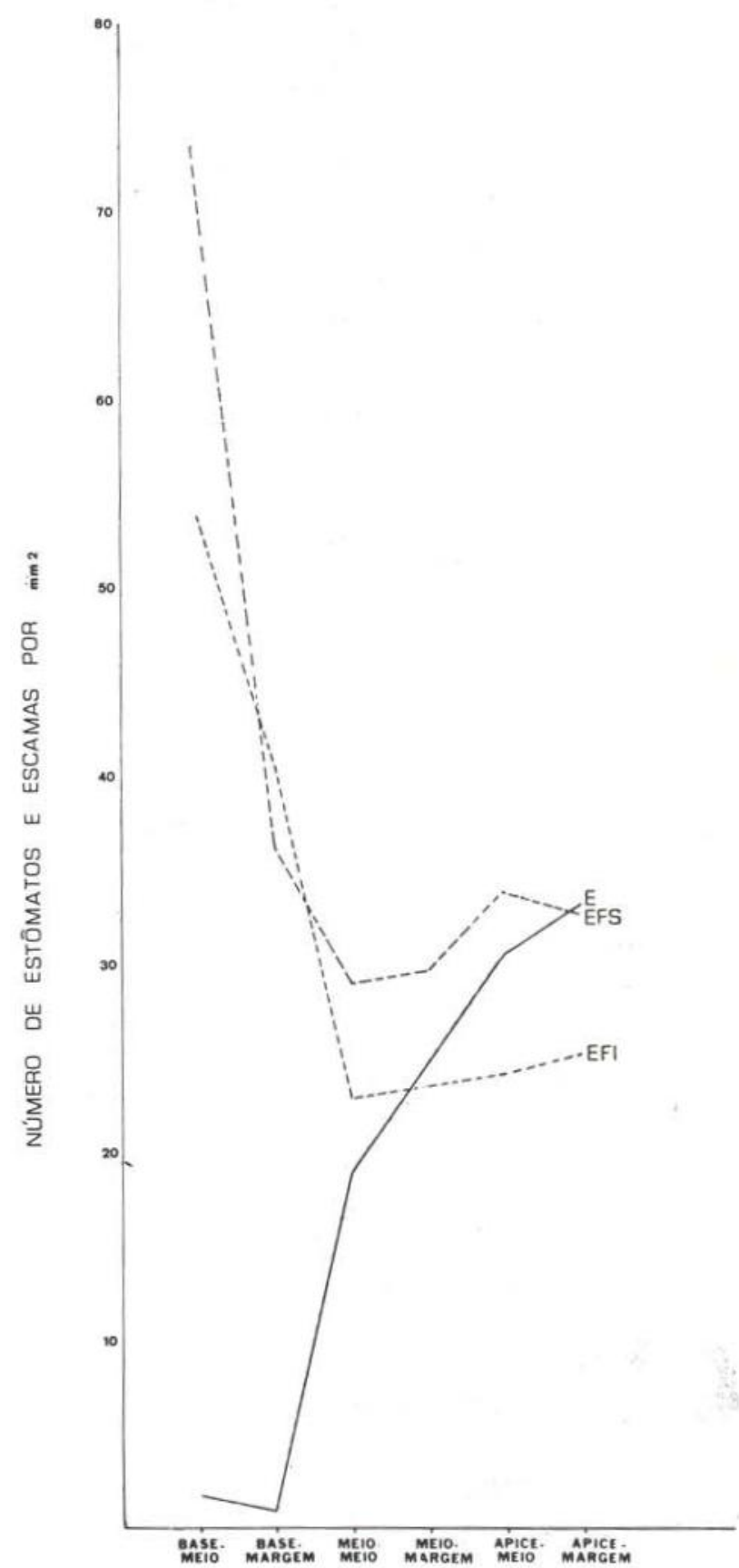

Gráfico 5 - Tillandsia adpressiflora. E - média do número de estômatos, EFS - média do número de escamas da face superior e EFI - média do número de escamas da face inferior. 
ESCAMAS: VISTA FRONTAL

E CORTE TRANSVERSAL

A observação de escamas em vista frontal, mostra uma diferença marcante entre as regiões base-meio e base margem e as demais regiões.

As escamas da região da base são pequenas, tendo, mais ou menos, metade do tamanho das escamas do meio e ápice. Possuem quatro células centrais, oito células pericentrais e logo após as células periféricas (Fig. 144). Nota-se nas células pericentrais um grande espessamento na parede externa, este pode faltar em algumas destas células. As células da periferia apresentam em conjunto um contorno muito irregular com grandes reentrâncias, quando se trata de escamas da margem, e o contrário, quando se trata de escamas do meio (Fig. 144, 145 e 146).

Em vista frontal, não se observam saliências ou depressões nas células destas escamas (Fig. 146 e 147).
Em corte transversal, as escamas mostram-se constituídas de: uma célula basal, quatro células do pedículo e células do escudo (Fig. 148), pode-se constatar também o espessamento das paredes externas das células pericentrais.

As escamas do meio e ápice são grandes. arredondadas ou um pouco irregulares (Fig. 149). Apresentam quatro células centrais, oito pericentrais, dezesseis subperiféricas e células periféricas. Estas últimas são bem uniformes e possuem cavidades em toda a su. perfície que, à primeira vista, parecem ser saliências.

As figuras 150 e 151 mostram detalhes das células centrais, pericentrais e subperiféricas respectivamente.

Em corte transversal, mostram uma ou duas células basais, quatro células do pedículo e células do escudo, nestas verificam-se as cavidades das células periféricas (Fig. 152, 153 e 154).

\section{Vriesea splitgerberi $(M e z)$ L. B. Smith \& Pittendrigh}

\section{EPIDERME SUPERIOR}

REGIÃO MEIO-MEIO :

A epiderme superior da folha de Vriesea splitgerberi é provida de escamas (Fig. 155).

As células epidérmicas estão dispostas em fileiras regulares com o eixo maior disposto no mesmo sentido do comprimento da folha. Têm a forma retangular alongada. As paredes anticlinais das células são pouco espessas e, às vezes, pouco onduladas (Fig. 155) .

As escamas estão distribuídas em filas quase regulares, mas com variações no espaço entre duas filas vizinhas e entre duas escamas da mesma fila.

O número médio de escamas por milímetro quadrado de superfície epidérmica é de 7,36 .

OUTRAS REGIÕES :

Em meio-margem, o aspecto da epiderme é como em meio-meio. O mesmo observa-se para ápice-meio e ápice-margem. Na base. meio e base-margem, as células epidérmicas têm, geralmente, a forma quadrada e são pequenas (Fig. 156). Nestas regiöes, as escamas ocorrem muito próximas sem formar fileiras (Fig. 157). Observa-se a presença de corpos silicosos esféricos-espinhosos no lume das células.

O número de escamas é maior na base e menor no meio (Gráfico 6) .

\section{EPIDERME INFERIOR}

REGIÃO MEIO-MEIO :

A epiderme inferior da folha de Vriesea splitgerberi é provida de escamas e estômatos.

As células epidérmicas possuem características semelhantes àquelas citadas para a epiderme superior. Estão dispostas em faixas de 

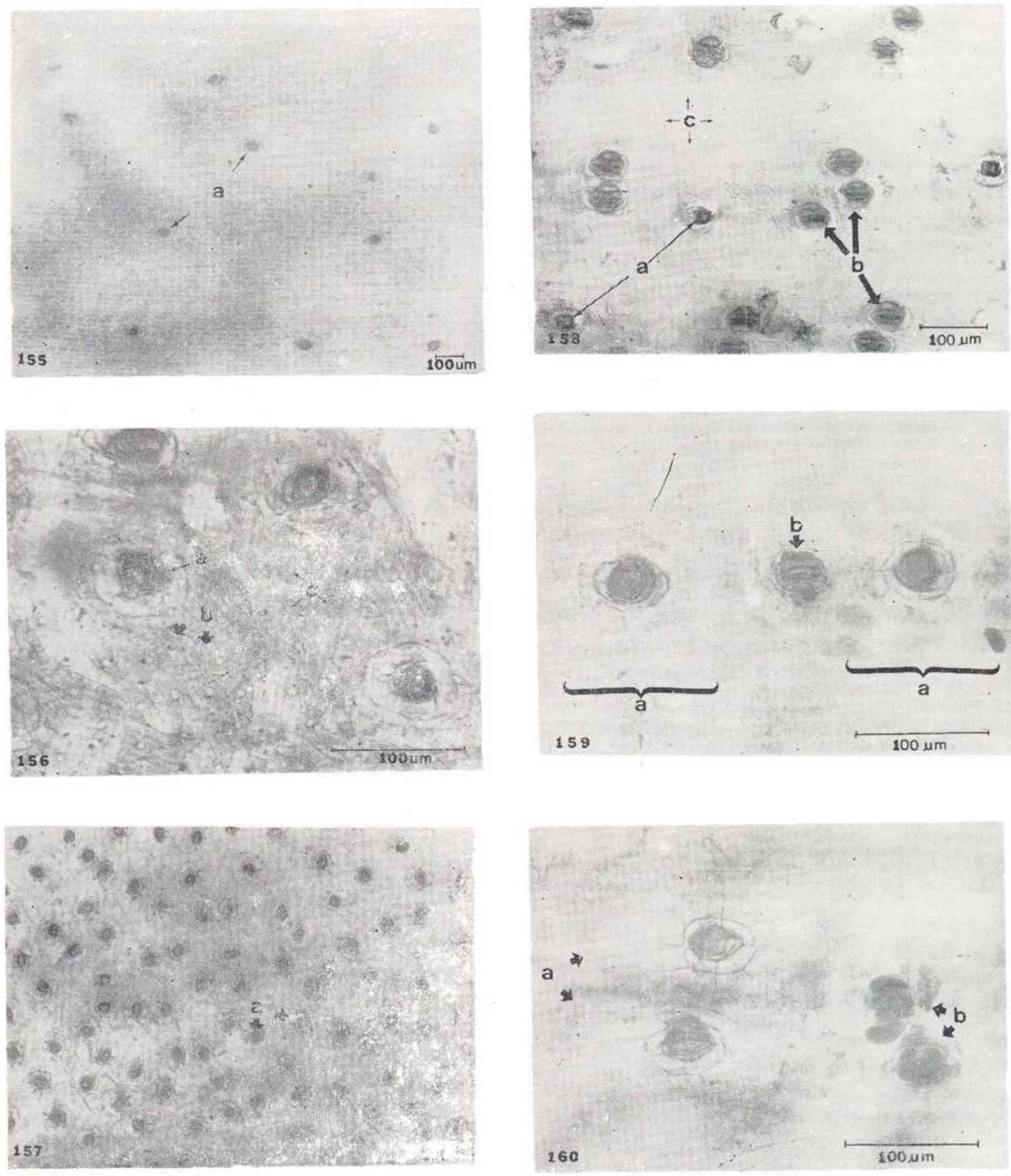

Fig. 155-157 - Vriesea splitgerberi. Epiderme superior em vista frontal. Fig. 155 - Meio-meio. a escamas. Fig. 156 - Base-margem. a - centro do escudo de uma escama, b - escudo de uma escama e c - corpos silicosos. Fig. 157 - Base-meio. a - escamas.

Fig. 158-160 - Vriesea splitgerberi. Epiderme inferior em vista frontal. Fig. 158 - Meio-margem. a - escamas, b - estômatos e c - células epidérmicas. Fig. 159 - Ápice-meio. a - escamas e b estômatos. Fig. 160 - Ápice-meio. a - escamas e b - estômatos. 
somente células epidérmicas e em faixas com escamas e estômatos. As células das faixas de células epidérmicas são geralmente alon. gadas, enquanto aquelas das faixas de escamas e estômatos são quadradas ou retangulares.

As faixas de estômatos e escamas são mais ou menos irregulares. Os estômatos dispõem-se, principalmente, em grupos de dois a cinco, entre duas escamas consecutivas de uma mesma faixa.

Apesar de as escamas não se encontrarem muito próximas dos estômatos, pode-se obser. var que, pelo tamanhio dos seus escudos, essas chegam, às vezes, a cobrí-los, mas nem sem. pre.

A média do número de escamas é de 14,52 escamas por milímetro quadrado e a mesma relaçäo para estômatos é de 38,3 .

\section{OUTRAS REGIÕES :}

Meio-margem, ápice-meio e ápice-marger.ı mostram características similares a meio-meio (Fig. 158). Os escudos das escamas ora cobrem os estômatos, ora não (Fig. 159 e 160) sendo este último aspecto mais constante.

$\mathrm{Na}$ base-meio e base-margem, não se nota a formação de faixas de estômatos, escamas e células epidérmicas (Fig. 161 e 162).

A média do número de escamas é maior na base e menor no meio; a média do número de estômatos decresce do ápice para a base (Gráfico 6) .

\section{REGIÃO MEIO-MEIO DA FOLHA EM CORTE} TRANSVERSAL (Fig. 163)

A epiderme superior, em corte transversal, mostra-se constituída de uma camada de células pequenas, pentagonais ou irregulares, com paredes periclinal interna e anticlinais pouco espessas e periclinal externa delgada e lume grande.

A hipoderme organiza-se com uma camada de células de tamanho médio, forma retangliar, pentagonal hexagonal ou irregular, paredes um pouco espessas e lume grande. A esta camada, segue-se o parênquima aqüífero - três a quatro camadas de células grandes ou médias, arredondadas, de paredes delgadas. Entre as células do parênquima aqüifero en. contramos feixes de fibras esclerenquimáticos (Fig. 163), em que as fibras se dispõem lado a lado uma das outras, margeando a superfície da folha. Estas fibras podem ocorrer também isoladamente, em grupos de duas, três ou mais no meio do parênquima aqüífero ou na base deste.

O parênquima clorofiliano ocorre com dois tipos celulares distintos: células do parênquima clorofiliano propriamente dito e células braciformes. As células do parênquima clorofiliano propriamente dito revestem lateralmente os feixes vasculares e se dispōem em duas ou três camadas abaixo do parênquima aqüifero nas regiões entre feixes vasculares; suas células são pequenas, geralmente arredondadas ou alongadas e com paredes delgadas.
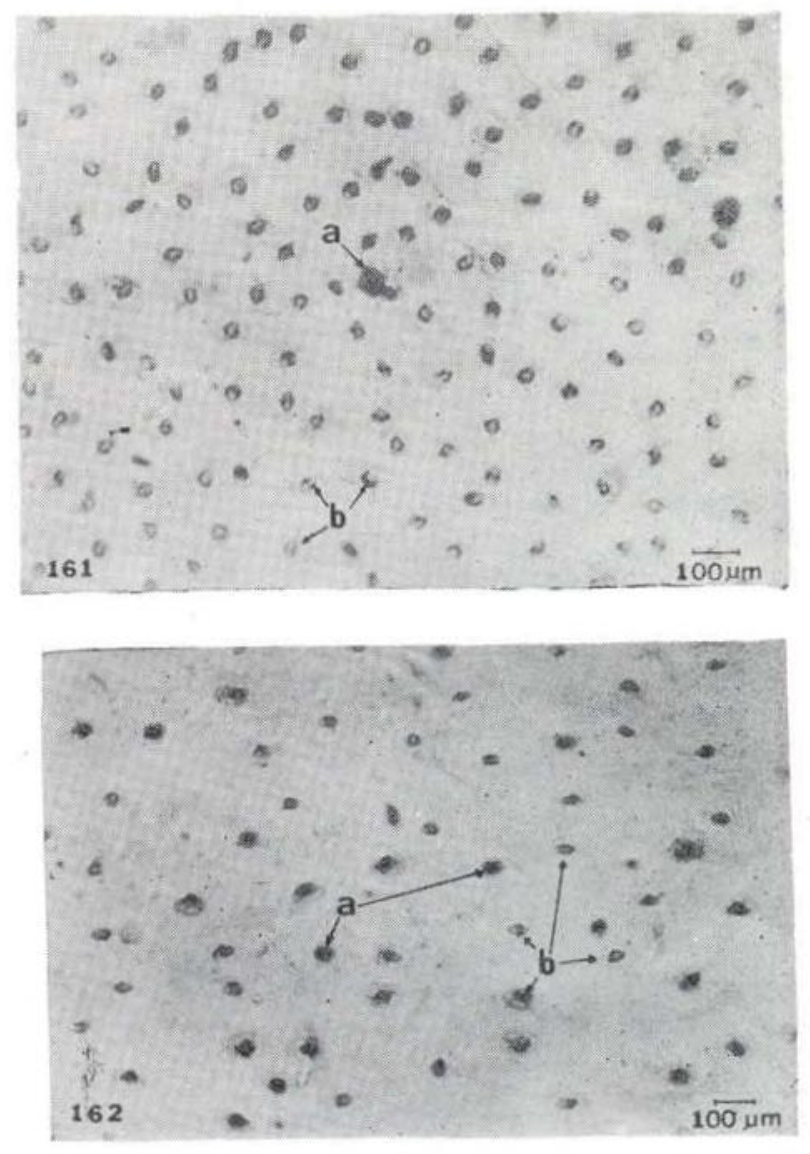

Fig. 161-162 - Vriesea splitgerberi. Epiderme inferior em vista frontal. Fig. 161 - Base-meio. a estômato e b - escamas. Fig. 162 - Base-margem. $\mathrm{a}$ - estômatos e b - escamas. 

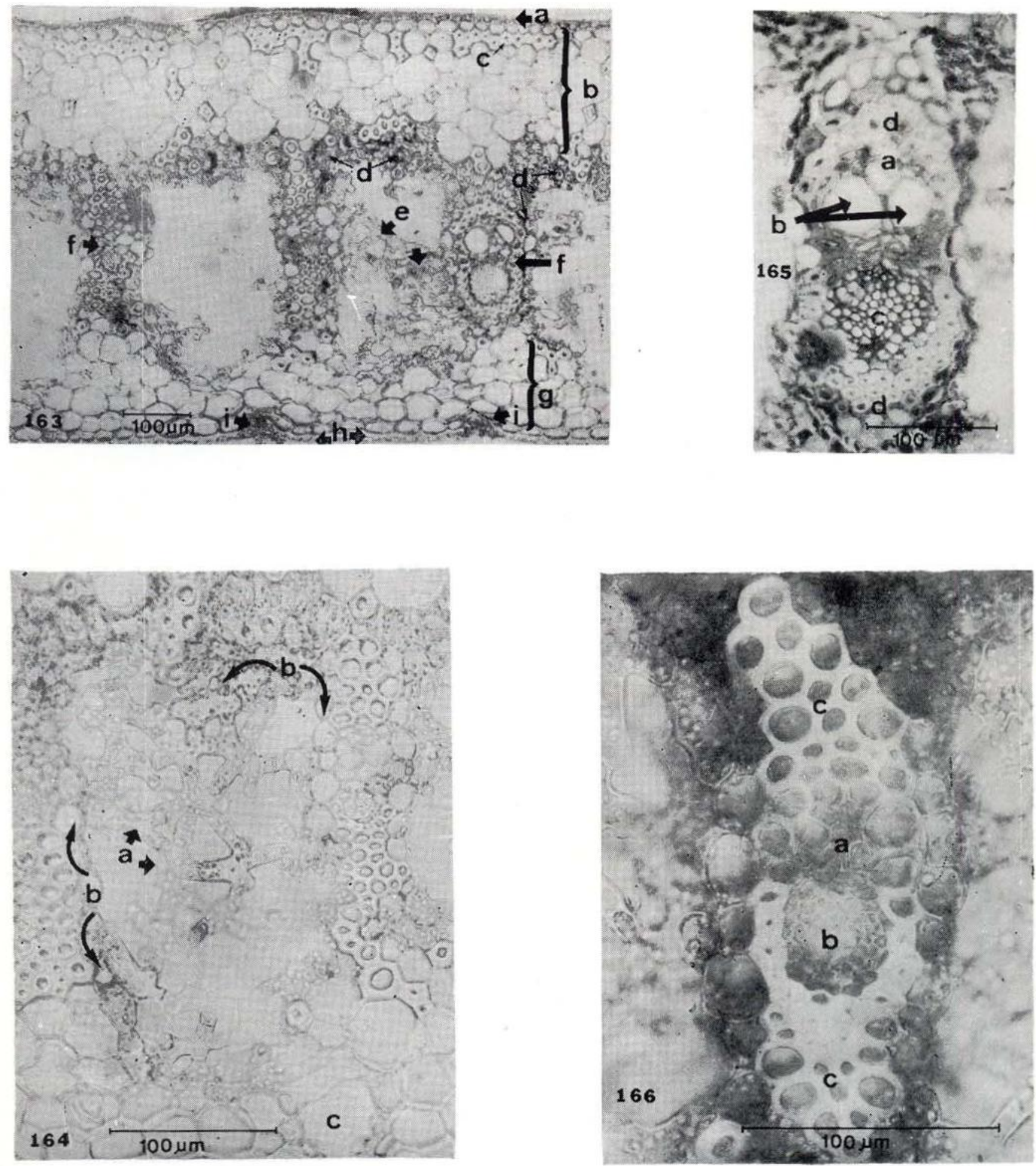

Fig. 163-166 - Vriesea splitgerberi. Corte transversal da região meio-meio. Fig. 163 - Aspecto geral. a epiderme superior, b - parênquima aqúifero, c - reforço esclerenquimático, d - parênquima clorofiliano, e - parênquima braciforme, $\mathrm{f}$ - feixes vasculares, $\mathrm{g}$ - parênquima aqüifero inferior, $\mathrm{h}-\mathrm{epiderme} \mathrm{in-}$ ferior e i - escamas. Fig. 164 - a - parênquima braciforme, b - parênquima clorofiliano e c - câmara subestomática. Fig. 165 - Feixe vascular principal. a - elementos de vasos do protoxilema, b - elementos de vasos do metaxilema, c - floema e d - reforço esclerenquimático. Fig. 166 - Feixe vascular secundário. a - xilema, b - floema e $\mathrm{c}-$ reforço esclerenquimático. 
As células do parênquima braciforme ocupam o espaço restante situado entre os feixes vasculares. Suas células possuem cerca de cinco a seis braços, paredes delgadas e muitos cloroplastos (Fig. 164). Na região onde ocorrem estômatos, existe um verdadeiro "canal de células braciformes que comunicam os es. paços do parênquima braciforme com a câmara subestomática.

Os feixes vasculares estão dispostos paralelamente um ao outro; lado a lado distribuem-se feixes mais desenvolvidos (feixes principais) e feixes menos desenvolvidos (feixes secundários). Um feixe principal tem o aspecto característico de um "oito". O "oito" propriamente dito é constituído de fibras esclerenquimáticas de diâmetro grande ou pequeno, lume diminuto naquelas fibras internas das extremidades superior e inferior e lume maior naquelas fibras que separam o xilema do floema. O xilema é composto de um ou dois elementos de vasos do protoxilema e dois elementos de vasos do metaxilema envolvidos por uma camada de células parenquimáticas (Fig. 165) .

Feixes secundários (Fig. 166) possuem um reforço maior nas extremidades.

Abaixo da região dos feixes, encontramos um parênquima cujas células são similares no que se refere ao tamanho e forma às do parênquima aqüifero. As camadas de células desse parênquima são interrompidas pelos "canais" aéreos que vão até os estêmatos.

A hipoderme e epiderme inferior têm 0 mesmo aspecto que as correspondentes superiores.

REGIÃo MEIO-MARGEM EM CORTE TRANSVERSAL (Fig. 167)

O aspecto estrutural da região meio-margem é como de meio-meio, sendo que nesta os feixes de fibras esclerenquimáticas, que margeiam a superfície superior, geralmente, estão contínuos com os feixes vasculares. $\mathrm{Na}$ margem propriamente dita, os parênquimas aqüiferos superior e inferior se unem num só.
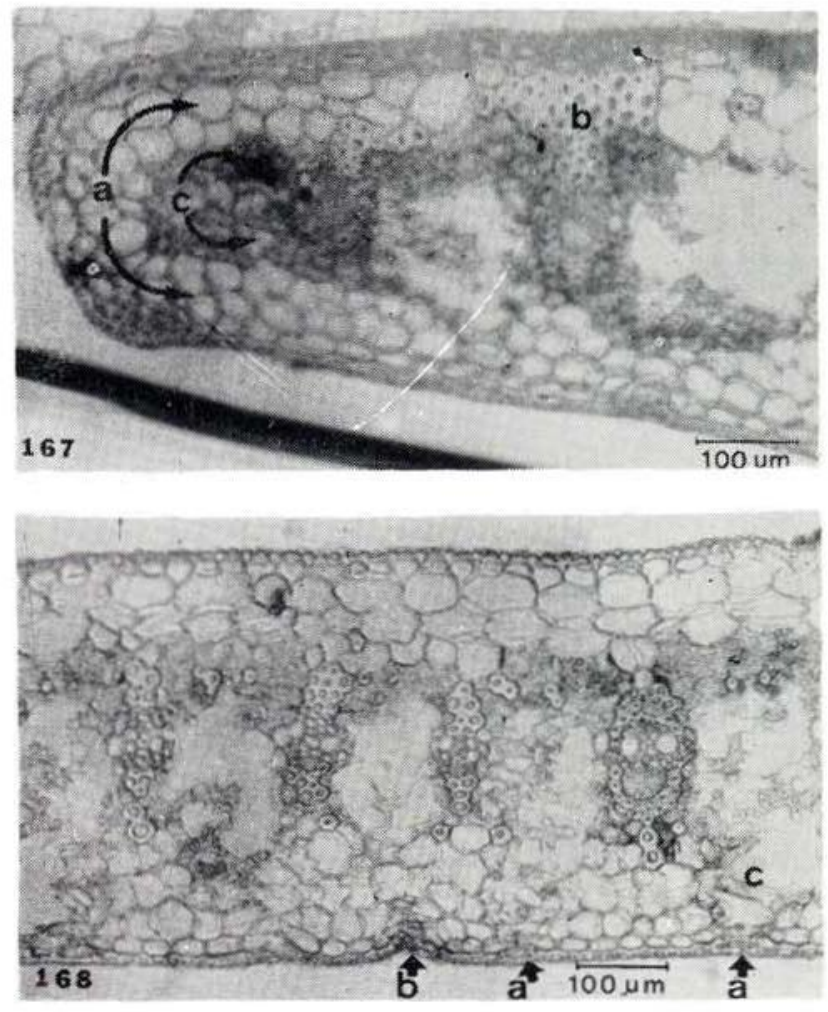

Fig. 167-168 - Vriesea splitgerberi. Fig. 167 - Corte transversal da região meio-margem. a - parênquima aqüífero, $\mathrm{b}$ - reforço esclerenquimático e c - parênquima clorofiliano. Fig. 168 - Corte transversal da região ápice-meio. Aspecto geral. a - estômato, b - escama e c - "canal" que liga os espaços do parênquima braciforme com a câmara subestomática.

\section{REGIÃO ÁPICE-MEIO EM CORTE TRANSVERSAL} (Fig. 168) .

Esta região apresenta uma diferença marcante da região meio-meio: não apresenta fibras esclerenquimáticas no parênquima aqüífero abaixo da epiderme superior.

\section{REGIP̃O BASE-MEIO EM CORTE TRANSVERSAL}

Na região base-meio, as células da epiderme superior e inferior são bem menores que as do meio-meio e do ápice, apresentam um iume pequeno, bem menor que das células cor respondentes da região meio-meio e este é por. tador de um corpo silicoso esférico-espinhoso. 

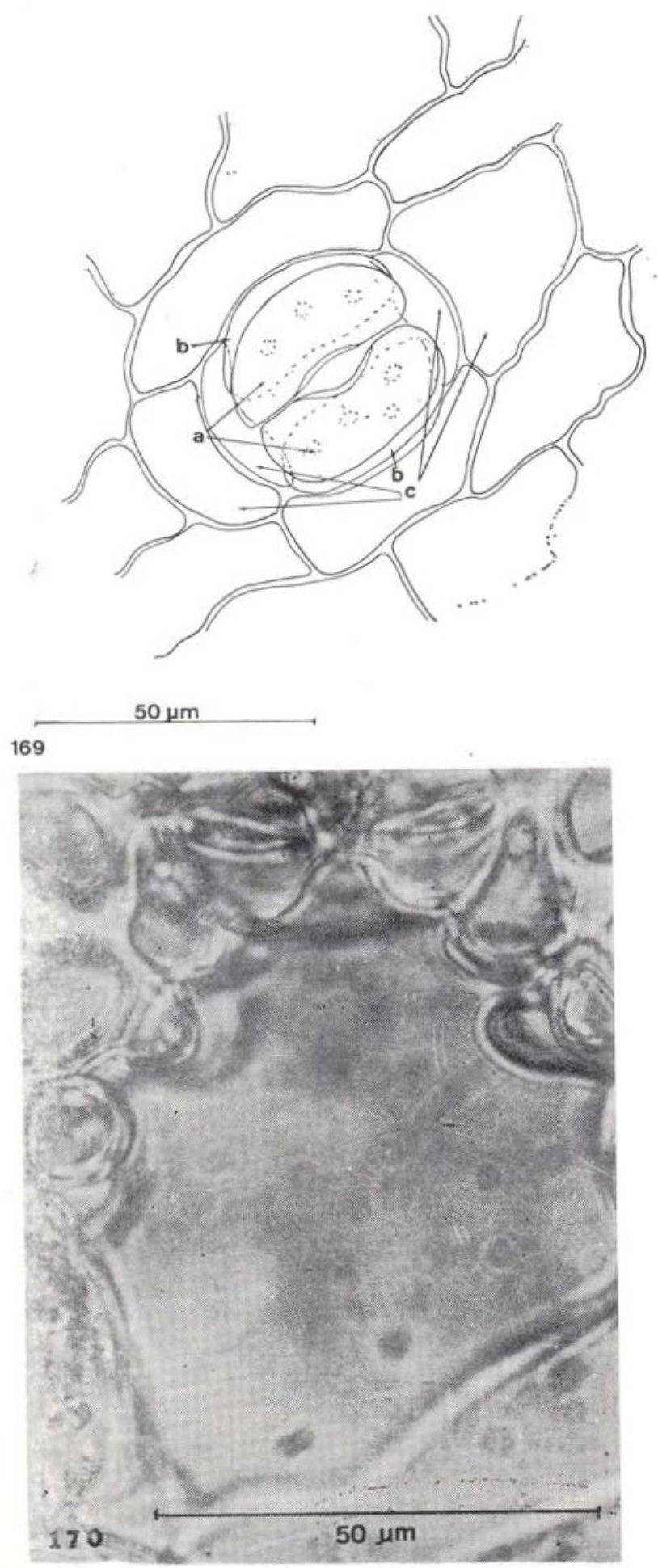

Fig. 169-170 - Vriesea splitgerberi. Estômatos. Fig. 169 - Epiderme inferior. Meio-meio. Vista frontal de um estômato. a - células-guardas, b - células subsidiárias e c - células vizinhas. Fig. 170 - Corte transversal das células-guardas de um estômato, em sua região mediana. Meio-meio. a células-guardas, b - células subsidiárias e c - células vizinhas.
As células do parênquima aqüifero inferior dispõem-se continuamente sem interrupções, tanto como no parênquima aqüífero superior.

Não ocorrem fibras esclerenquimáticas isoladas nem em grupo.

Observam-se, às vezes, feixes vasculares atravessando o parênquima braciforme e unindo feixes paralelos.

A camada de células sobre a epiderme inferior apresenta células com paredes espessas. pontuações e o lume grande.

\section{ESTÔMATOS: vISTA FRONTAL E CORTE TRANSVERSAL E LONGITUDINAL}

Os estômatos de Vriesea splitgerberi, em vista frontal, mostram-se envolvidos por quatro ou mais células vizinhas, que, normalmente, possuem paredes menos onduladas que as demais células epidérmicas (Fig. 169).

Em corte transversal, pode-se observar a posição das células subsidiárias (Fig. $170 \mathrm{e}$ 171) e constatar que o lume das células-guar-

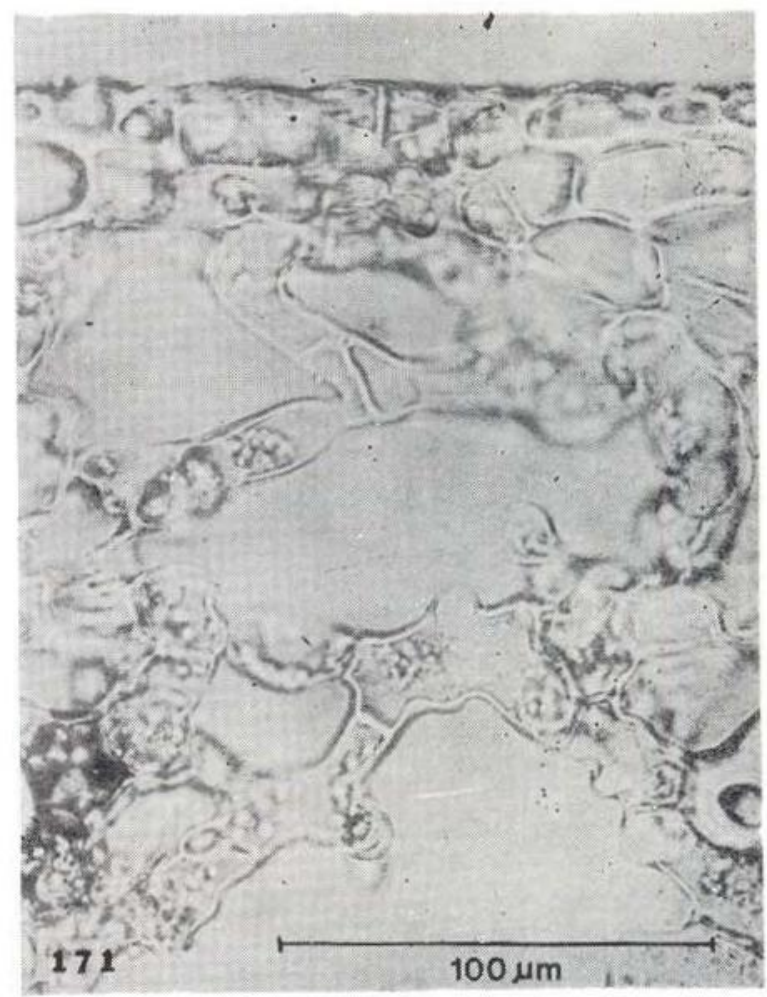

Fig. 171 - Vriesea splitgerberi. Corte transversal das células-guardas de um estômato em sua região polar. Ápice-meio. 

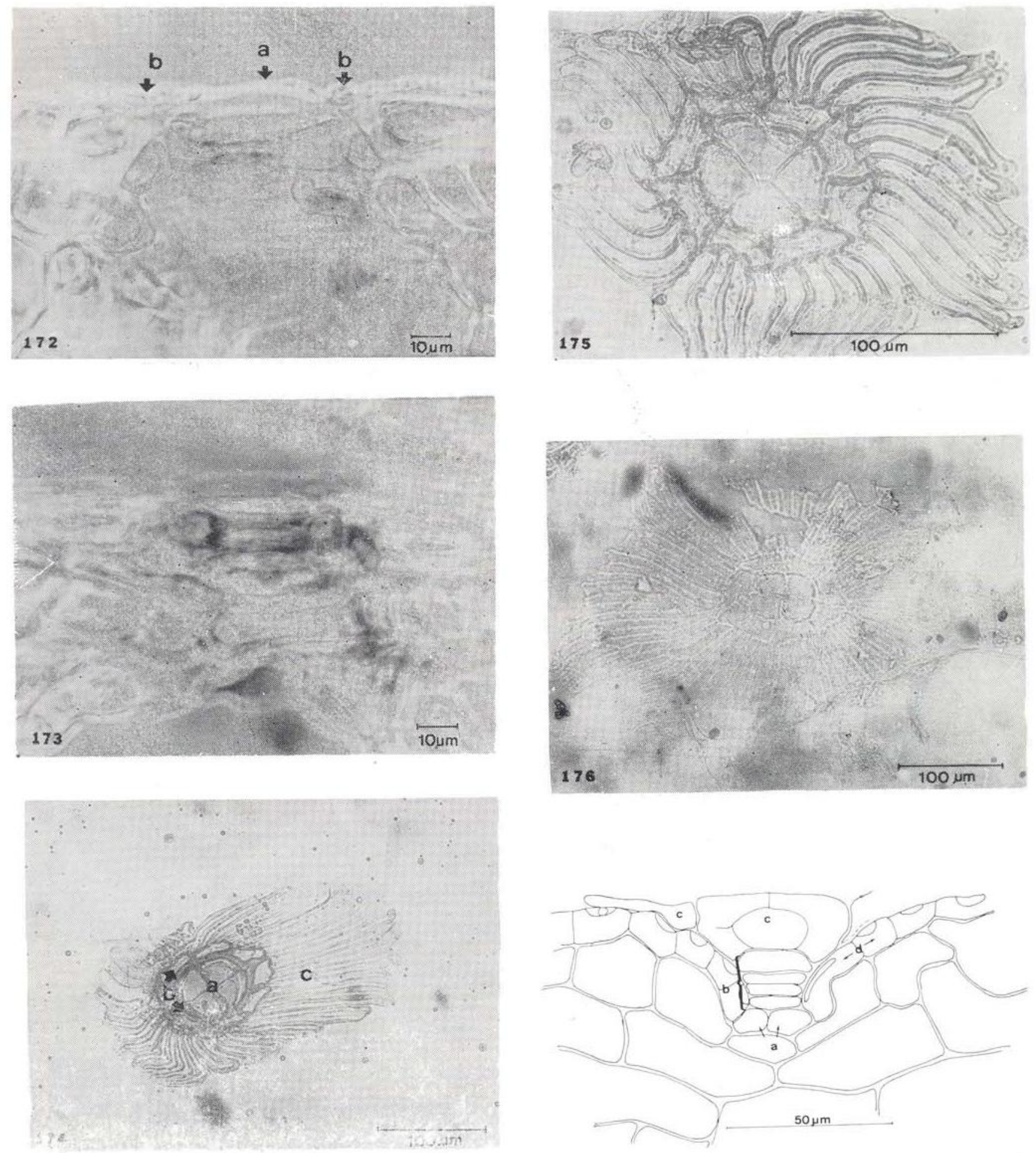

Fig. 172-173 - Vriesea splitgerberi. Meio-meio. Estômato, Fig. 172 - Corte longitudinal da célula-guarda de um estômato próximo à parede lateral externa da célula-guarda. a - célula-guarda e b - células vizinhas. Fig. 173 - Corte longitudinal da célula-guarda de um estômato próximo à parede lateral interna da mesma. Fig. 174-177 - Vriesea splitgerberi. Escamas em vista frontal. Fig. 174 - Epiderme inferior. Base-meio. a - células centrais, b - células pericentrais e c - células periféricas. Fig. 175 - Epiderme inferior. Base-margem. Fig. 176 - Epiderme superior. Meio-meio. Fig. 177 - Escama. Epiderme superior. Base-meio. Corte transversal. a - células basais, b - células do pedículo, c - células do escudo e d - células epidérmicas. 
das lembra uma lente biconvexa, quando o corte destas é mediano, quando o corte é na região polar o lume toma uma forma triangular.

Um corte longitudinal da célula-guarda (Fig. 172 e 173) mostra o estreitamento que sofre o lume da célula na região mediana da mesma.

ESCAMAS: VISTA FRONTAL E CORTE TRANSVERSAL

As escamas, em vista frontal, mostram algumas diferenças quanto à região de ocorrência; assim sendo, observa-se que uma escama da região base-meio (Fig. 174) tem a forma irregular mas sem apresentar grandes reentrâncias em sua periferia; possui quatro células centrais, oito pericentrais e células pe. riféricas, sendo que as células pericentrais mostram as paredes anticlinal interna $e$ as anticlinais laterais muito espessas.

Uma escama da região base-margem já mostra uma forma irregular com grandes reentrâncias na periferia (Fig. 175); possui quatro células centrais, oito pericentrais e células periféricas, mas as pericentrais não apresentam espessamento algum em suas paredes.

As escamas das regiões meio e ápice têm a forma arredondada irregular sem reentrâncias (Fig. 176). A área que cobrem é quase duas vezes maior que as escamas da base. $O$ número de células centrais e pericentrais é semelhante ao daquelas.

O corte transversal de uma escama mostra que esta apresenta uma ou duas células basais, quatro células do pedículo e células do escudo (Fig. 177).

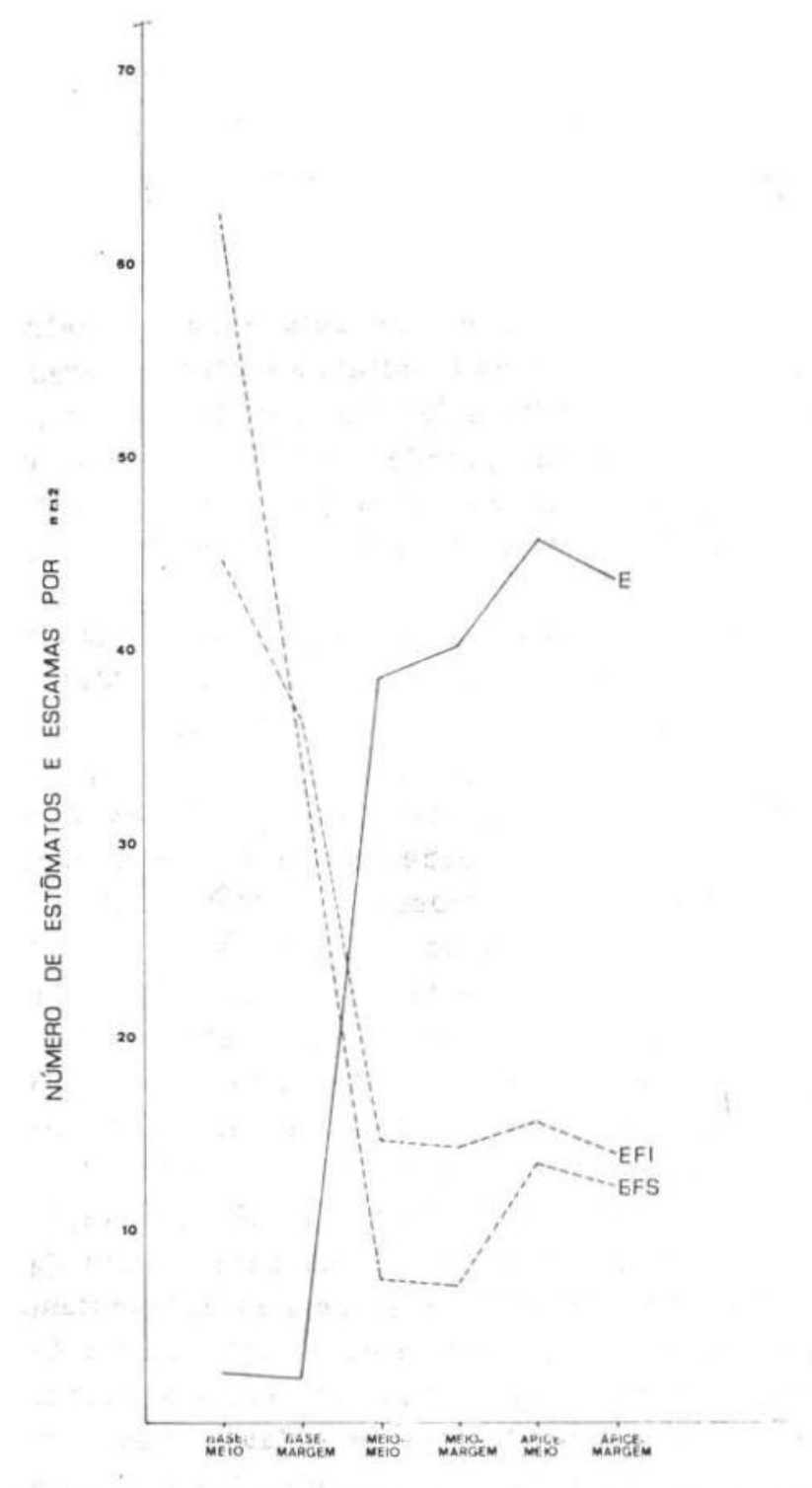

Gráfico 6 - Vriesea splitgerberi. E - média do número de estômatos, EFS - média do número de escamas da face superior e EFI - média do número de escamas da face inferior. 


\section{DISCUSSÃO E CONCLUSÕES}

Verificou-se que, nas seis espécies estudadas, as epidermes mostram a estrutura carac. terística para toda a família: parede periclinal externa delgada. parede periclinal interna e anticlinais espessas, lume geralmente pequeno e portador de corpo silicoso esférico (Tomlinson, 1969).

Krauss (1949) comenta que as células da epiderme de Ananas comosus (L.) Merr. apresentam seu diâmetro maior disposto em ângulo reto em relação ao eixo longitudinal da folha. Menciona também vários autores que trataram de outras espécies de Bromeliaceae, inclusive Ananas comosus (L.) Merr., para os quais este fato passou despercebido ou foi ignorado. Isto não está de acordo com os dados obtidos neste trabalho, pois em todas as espécies estudadas, inclusive uma espécie de Ananas, as células epidérmicas apresentaram seu diâmetro maior disposto na mesma direção do comprimento da folha. A observação de Kráuss poderia ser correta para a base da folha, onde geraimente as células apresentamse pequenas ou irregulares e, principalmente para a margem das folhas com acúleos quando estes ocorrem. Na margem das folhas com acúleos, as células têm seu eixo maior disposto em ângulo reto em relaçăo ao comprimento $\mathrm{da}$ folha, o que pode ser visto freqüentemente, também, na base das folhas.

Nas espécies tratadas neste trabalho, observa-se que Ananas ananassoides e Streptocalyx poeppigii apresentam, em toda a epiderme superior da folha, células epidérmicas pequenas, quadradas ou retangulares; Aechmea setigera e Vriesea splitgerberi possuem células pequenas apenas nas regiões base-meio $e$ base-margem e Aechmea mertensii e Tillandsia adpressiflora têm apenas as células da basemargem pequenas. Ananas ananassoides apresenta, além das características citadas acima, as células da margem um pouco alongadas, o que foi observado também por Krauss (1949) em Ananas comosus (L.) Merr. .
Foi observado que as células localizadas entre escamas próximas e entre escamas e estômatos apresentam o tamanho reduzido e forma irregular; na região basal, onde geralmente o número de escamas é maior, as células têm o tamanho pequeno e forma irregular normalmente. Isto mostra que o tamanho médio das células e a forma regular ou irregular estão intimamente ligados ao número de escamas. Neste caso, acredita-se que as escamas !imitam o crescimento das células. Por outro lado, comparando-se espécies diferentes, as que apresentaram as células de maior tamanho médio não foram aquelas que possuiam - menor número de escamas. Isto permite supor que o número de escamas pode influenciar o crescimento das células epidérmicas apenas dentro da mesma folha, não sendo porém, o responsável direto peìo tamanho das células epidérmicas numa determinada espécie. Outros fatores poderiam estar influenciando.

As únicas relações encontradas entre o tamanho menor das células e espécies, foram de que estas espécies são provavelmente esjécies menos evoluídas e são as únicas espécies em que as escamas estão distribuídas em filas mais ou menos regulares em todas as regiōes da folha.

Considerando o aspecto ondulado das paredes, De Bary (1884) comenta que dentro de uma planta e plantas diferentes da mesma esगécie, o grau de ondulação das paredes celulares varia rom as condiçôes ambientais. São lisas em regiões secas e mais onduladas nas regiões mais úmidas.

De um modo geral, todas as plantas estudadas apresentaram alto grau de ondulação das paredes celulares anticlinais; levando em consideração que na campina a umidade relativa é de $81 \%$ e $90 \%$ e na campinarana é de $91 \%$ e $97 \%$, reforça-se a hipótese de De Bary. 
Contudo, a espécie que possui paredes menos onduladas é Vriesea splitgerberi, que se encontra próxima à campinarana, onde a umidade é maior que na campina.

Em relação à espessura da parede periclinal interna, Wittmack (1888), Richter (1891) e Linsbauer (1911) acreditavam que esta varia de acordo com o habitat das espécies, com: paredes mais espessas em espécies de habitat muito seco, de forma que tal espessamento protege os tecidos internos em ambientes desfavoráveis

Com exceção de Vriesea splitgerberi, todas as espécies da campina e limites desta com campinarana mostraram tais paredes muito espessas. Observando os dados sobre umidade, pode-se notar que no caso não haveria necessidade de tal espessamento.

Talvez o espessamento da parede represente uma proteção contra o excesso de iluminação, o que justifica Vriesea splitgerberi ter paredes menos espessas e desenvolver-se à sombra

No que se refere à presença de corpos silicosos, encontrados nos lumes das células epidérmicas, muitos autores têm-na relacionada, em outras espécies de monocotiledôneas, com uma redução da perda de água (Yoshida, Ohnishi \& Kitagishi, 1962). Desta forma, podese pensar que a estrutura foliar de Bromeliaceae é um complexo de organização altamente adaptada a problemas hídricos, associando-se à presença de corpos silicosos outros fatores já relacionados anteriormente.

Krauss (1949) comenta que corpos silicosos são altamente refrativos. Baumert (1907) acreditava que os corpos silicosos poderianı servir na dispersão da luz; pensou ter descoberto uma possível função para os corpos sil:cosos: proteção contra muita iiuminação, não pode porém, comprovar tal hipótese como ver. dadeira. Na campina, Ananas ananassoides. que possui corpos silicosos grandes, é encontrado à sombra. Contudo, uma vez que esta espécie ocorre em lugares fora da campina, muito expostos à iluminação e desenvolve-se bem, pode-se pensar que sua ocorrência na campína, à sombra, seja um habitat secundárıo.
Solereder e Meyer (1929) referem-se à sílica ausente de paredes de células epidérmicas finas em espécies de Canistrum, Guzmania, Pitcairnia, Tillandsia e Vriesea. Nas espécies tratadas açui a presença de corpos silicosos is praticamente constante em espécies com células epidérmicas de paredes espessas. Vriesea splitgerberi possui na região basal as paredes anticlinais e periclinal interna espessas e tem corpo silicoso. Na região do meio e ápice, as células têm as referidas paredes espessas, mas como o tamanho da célula é maior, o lume tamibém o é e não tem corpo silicoso. É possível que mais do que o espessamento, a pre sença do corpo silicoso estaria relacionada com o tamanho do lume das células epidérmicas.

Nas folhas de Aechmea setigera, a ocorrência de corpos silicosos nas células da epiderme mostra-se um tanto irregular. Os corpos silicosos são encontrados em todas as regiões da folha, mas principalmente nas células localizadas próximas às escamas e estômatos. Em corte, as células epidérmicas de Aechmea setigera apresentam paredes muito espessas, lume muito pequeno, portanto, se a teoria da relação entre espessura da parede e lume e presença de corpo silicoso fosse correta deveriam conter corpo silicoso, o que não acontece. Não foi possível nesta espécie fazer uma correlação entre a ocorrência de corpos silicosos e um fator que a delimitasse.

Quanto à disposição, número, tamanho e estrutura das escamas, em relação às regiões delimitadas dentro da folha, observa-se que Ansnas ananassoides e Streptocalyx poeppigii apresentam escamas dispostas em fileiras quase que invariavelmente em toda a extensão foliar; Aechmea setigera, Aechmea mertensii e Vriesea splitgerberi têm suas escamas distribuídas em fileiras apenas no ápice e no meio e Tillandsia adpressiflora não tem suas escamas em filas; a distribuição destas não obedece a uma padronização que pudesse ser observada.

Dentro da folha de cada espécie, verificase que a região que gerailmente mostra maior número de escamas é a região basal. Poderia ser que dentro de uma folha a organização das 
ascamas em fileiras estivesse ligada ao número de escamas.

Entre espécies diferentes, nota-se que Tillandsia adpressiflora tem maior número em toda a extensão foliar do que nas outras espé. cies e não possui a típica distribuição das escamas em fileiras. Aechmea mertensii possui em todas as regiões da folha o número de escamas menor que das folhas de Ananas ananassoides $\in$ Streptocalyx poeppigii e só possui escamas em fileiras nas regiōes do meio e ápice da folha, enquanto estas duas últimas espécies mantêm uma organização mais ou menos constante em relação às fileiras.

Quanto ao tamanho e estrutura, verifica-se que a tendência é haver especialização funcional das escamas, conforme a região em que se cncontram. Em Aechmea setigera, Tillandsia adpressiflora e Vriesea splitgerberi as escamas da base têm geralmente a metade do tamanho daquelas do meio e ápice. Nas demais espécies, este tamanho é mais ou menos semielhante entre as regiões. Tomlinson (1969) diz que de um modo geral as escamas da base são maiores que as escamas das outras partes da folha.

Além disso, nota-se uma grande diferença estrutural, principalmente, em Tillandsia adpressiflora e Vriesea splitgerberi entre escamas da base e meio/ápice. Nas escamas da base da folha de Tillandsia adpressiflora, ocor$r \in$ menor número de células do escudo e com espessamento na parede externa das células pericêntricas, já nas escamas do meio e ápiç o número de células do escudo é maior e apresentam cavidades nas células periféricas. As escamas da base-meio de Vriesea splitgerberi têm as paredes internas das células pericêntricas espessadas.

Relacionando-se tais dados com as possiveis funções realizadas pelas escamas nota-se que :

- se as escamas estiverem relacionadas com a absorção de água (Schimper, 1884) e esta acumula-se na região basal da folha, pode-se pensar que as escamas desta região, que por mais tempo =permanecem em contato com a água sejam mais adaptadas a esta função do que as demais;
- se a função de absorção de água pelas escamas é feita principalmente por suas células vivas e se estas são as células centrais do escudo, células do pedículo e células basais então o caráter adaptativo à função de absorção seria desenvolvido nestas células. Neste caso, as escamas da base não precisariam ter um grande escudo, o que na realidade não pos. suem, mas sim aumentar a superfície de absorção, que seria representada pelo maior número de escamas, o que ocorre na região basal da folha.

Considerando-se ainda o espessamento das paredes externas das células pericentrais, tem-se a impressão de que na região basal da folha a absorção de água ocorre diretamente pelas células centrais, passando destas para o pedículo e não lateraimente pelo espaço entre escudo e epiderme.

Já as escamas da regiăo do meio e ápice da folha poderiam estar mais adaptadas a outras funções, como proteção. Assim sendo, estas escamas não necessitariam ocorrer em grande número, desde que representassem uma cobertura eficiente sobre a epiderme.

No caso de Tillandsia adpressiflora, as céiulas periféricas do escudo possuem cavidades sobre cuja função nada se sabe. Tomlinson (1969) encontrou em Tillandsia recurvata uma estrutura de aspecto semelhante à qual se refere como "verrugas" (warts). Em Tillandsia adpressiflora, a primeira impressão que se tem é de que as células dos escudos estão cobertas por papilas. Uma revisão detalhada da es:rutura em níveis sucessivos de focalização e em cortes, revelou que na realidade as "papilas" nada mais são do que cavidades.

Tomlinson (1969) notou que Tillandsia re. curvata, num experimento de Baumert, aprescntou a maior resistência à insolação. Se a estrutura descrita por Tomlinson para as escamas distais da folha de Tillandsia recurvata for semelhante à encontrada em Tillandsia adpressiflora então suas funções devem ser semeIhantes.

Em todas as espécies estudadas, verificou-se que o número de escamas é maior no meio da foiha e menor na margem. 
A estrutura das células da epiderme inferior das folhas é semelhante à estrutura das células da epiderme superior.

Em Ananas ananassoides, Streptocalyx poeppigii, Aechmea setigera e Vriesea splitgerberi, os estômatos e escamas estão distribuídos em faixas na região do meio e do ápice da folha, porém, na base dispõem-se em filas.

Aechmea mertensii possui os estômatos e escamas dispostos em filas, praticamente em todas as regiões da folha, já em Tillandsia adpressiflora, a distribuição de escamas e estômatos não é padronizada.

Em Aechmea mertensii e Vriesea splitgerberi, (menos freqüentemente) os escudos das escamas não cobrem os estômatos.

Devido ao relacionamento estrutural entre escamas e estômatos, que ocorre em Ananas ananassoides, Aechmea setigera, Streptocalyx poeppigii e Tillandsia adpressiflora, pode-sa supor que haja também um relacionamento funcional de proteção contra transpiração, função esta já citada por vários autores.

Assim, caso todas as espécies fossem do tipo de metabolismo ácido crassuláceo, como ocorre normalmente em Bromeliaceae, teriam seus estômatos abertos à noite. Para que tal ocorresse, seria necessário que as escamas mantivessem seus escudos levantados, o que exigiria uma certa quantidade de água (as escamas mantêm-se colapsadas contra a superfície epidérmica, quando estão secas). $\mathrm{Na}$ campina, à noite, com uma pequena baixa de temperatura, condensa-se vapor d'água e as superfícies foliares ficam completamente molhadas. isto seria o suficiente para permitir que os escudos das escamas se levantassem, desobstruindo a entrada para a penetração do ar. Durante o dia as escamas estariam colapsadas, impedindo que ocorresse transpiração através dos estômatos.

$\mathrm{Na}$ maioria das espécies, existem projeçōes laterais das células da margem da câmara subestomática em direção à entrada da mesma no sentido de obstruí-la, impedindo a perda de água. No caso de Ananas ananassoides, as céiulas da epiderme vizinhas do estômato penetram pela região polar dos mesmos, de for- ma que fecham parcialmente a entrada da câmara subestomática. Tomlinson (1969) também observou este aspecto em Ananas bracteatus.

Em Aechmea mertensii, onde as escamas não cobrem os estômatos, estes possuem projeções esclerificadas provenientes da margem da câmara subestomática, como uma obstrução permanente, ou quase permanente.

O número de estômatos, em todas as espécies, cresce da base para o ápice, havendo uma pequena variação entre o número da margem e do meio de uma mesma região.

Como a base das foihas acumula água e os estômatos não efetuam muitas trocas gasosas nestas condições, há poucos estômatos nesta regiào. O número de estômatos cresce em direção ao ápice, onde a água absorvida, principalmente na base, seria transpirada.

A relação média de estômatos para escamas na epiderme inferior em cada espécie é:

\section{- Aechmea mertensii \\ - Ananas ananassoides \\ - Streptocalyx poeppigii \\ - Atchmea setigera \\ - Vriesea splitgerberi \\ - Tillandsia adpressiflora}

$\begin{array}{ccc}\text { Estômato } & \text { Escama } \\ 2,98 & : & 1 \\ 1,53 & : & 1 \\ 1,53 & : & 1 \\ 1,50 & : & 1 \\ 1,24 & : & 1 \\ 0,57 & : & 1\end{array}$

Segundo Tomlinson (1969), esta proporção é maior em P.tcairnioideae e Bromelioideae e menor em Tillandsioideae, decrescendo das menos especializadas (terrestres) para as mais especializadas (epífitas).

$\mathrm{Na}$ relação anterior, vê-se que a ordem está mais ou menos dentro da observação de Tomlinson, com exceção de Aechmea mertensii e Vriesea splitgerberi. Aechmea mertensii com maior número de estômato por escama, é uma espécie muito encontrada na campina como epífita, só ocorrendo como terrestre acidentalmente, quando o ramo da árvore, sobre o qual se encontra, cai. Uma vez que nesta espécie as escamas não estăo estruturalmente relacionadas com os estômatos, o que justifica, em parte. o fato de possuir maior número de estômatos por escamas, pode-se supor que as projeções esclerificadas, que obstruem a en- 
trada da câmara subestomática, sejam rea!mente eficientes no que se refere à proteção contra perda de água.

Caso semelhante ocorre com Vriesea splitgerberi, onde a relação de estômato por escama é quase de $1: 1$, a qual, no entanto, é encontrada, principalmente, como terrestre. Como os escudos de suas escamas não cobrem totalmente os estômatos, a proporção de estômatos para escamas não é uma relação importante para caracterizar o hábito da planta.

Em Ananas ananassoides, ocorrem estruturas semelhantes a estômatos na região basemeio das folhas, como não foi possível verificar a verdadeira natureza dessas estruturas através de cortes e devido à sua pequena ocorrência, não as discutimos aqui.

Sobre a estrutura da folha, organização e desenvolvimento de seus tecidos, observa-se que Aechmea setigera, Ananas ananassoides e Streptocalyx poeppigii apresentam as camadas de células superficiais esclerificadas. $\mathrm{Na}$ região basal da folha de Aechmea setigera, a hipoderme superior possui paredes delgadas. Em Tillandsia adpressiflora, somente a hipoderme inferior é esclerificada, o mesmo ocorrendo em Vriesea splitgerberi. Nas folhas de Aechmea mertensii, parece que o espessamento das paredes das células epidérmicas prolonga-se entre as células da camada adjacente, mas não se nota um nítido espessamento das paredes destas células.

Tietze (1906) considera a presença de camadas de células superficiais esclerificadas como característica de espécies terrestres não especializadas.

Tomlinson (1969) cita a ocorrência de camadas superficiais esclerosadas em espécies de Ananas, Streptocalyx e outros gêneros. Para Aechmea, indica a ocorrência de camada adaxial esclerótica contínua, uniforme ou algumas vezes com filas de células curtas abaixo de filas de escamas epidérmicas. Em Tillandsia e Vriesea, a hipoderme superior e inferior não se mostra normalmente com espessamento.

$\mathrm{O}$ parênquima aqüífero apresenta-se muito desenvolvido nas espécies Ananas ananassoides e Aechmea mertensii. Nas demais espé- cies, tem-se a impressão de que há uma redução estrutural acompanhada de duplicidade funcional dos parênquimas. Assim sendo, a função de reservar água estaria sendo desenvolvida pelo parênquima clorofiliano. Observa-se que de um modo geral as células do parênquima clorofiliano (com exceção das braciformes) possuem número reduzido de cloroplastos em relação ao volume da célula. Na campina onde a intensidade luminosa é muito alta, a distribuição da água armazenada por toda a folha talvez fizesse com que os raios luminosos fos$\mathrm{sm}$ filtrados. Nota-se que espécies, como Aechmea mertensii, sujeitas à muita exposição à luz solar, têm poucos cloroplastos e estes estão muito espalhados.

Em folhas de Tillandsia adpressiflora e Vriesea splitgerberi, o parênquima aqüífero ocupa as camadas superior e inferior do mesófilo, o parênquima clorofiliano (com exceção do braciforme) situa-se num espaço muito restrito, em compensação suas células estão repletas de cloroplastos.

As espécies que têm reforço de fibras esclerenquimáticas são Ananas ananassoides, Streptocalyx poeppigii (na base), Aechmea setigera e Vriesea splitgerberi (meio e ápice). Nas espécies com folhas mais espessas, este reforço é constituído por feixes de fibras, com aspecto de "ninhos" em corte transversal. Enı Vriesea splitgerberi, o reforço apresenta-se sob a forma de fibras isoladas ou agrupadas em taixas, principalmente como um esqueleto de sustentação sobre e, às vezes, sob o parênquima braciforme e no parênquima aqüífero superior.

Aechmea mertensii tem folhas relativamente finas e năo possui reforço extravascular. inclusive o reforço nos feixes vasculares é menos desenvolvido do que o de outras espécies. Em Tillandsia adpressiflora, não ocorre reforço de fibras além daquele dos feixes vasculares, em compensação estes são bem desenvoividos.

O parênquima braciforme é muito desenvolvido, em relação ao volume da folha em Tillandsia adpressiflora e Vriesea splitgerberi. Em corte transversal, verifica-se que estes es. tão em contato direto com a câmara subesto- 
mática. Tomlinson (1969) comenta que este tecido é pouco desenvolvido em epífitas extremas do gènero Tillandsia. Em Aechmea mertensii, este parênquima é pouco desenvolvido, nas demais espécies é mais ou menos proporciona! ao volume foliar.

Os feixes vasculares, em todas as espécies, mostram num mesmo corte uma variação no tamanho dos feixes vasculares e no reforço de fibras.

Nota-se que a região dentro da folha que mais variações apresenta, quando comparáda com a região meio-meio, é a base. Nesta podese constatar uma função específica na maioria dos casos: a de armazenamento de amido.

De um modo geral, observa-se que:

- Ananas ananassoides mantém um padrão estrutural mais ou menos semelhante ao observado nas outras espécies de Ananas. Tem uma estrutura com garantias de sobrevivência num ambiente xerofítico, principalmente pela pre. sença do parênquima aqüífero desenvolvido pelos estômatos em cavidades com câmara subestomática parcialmente obstruída por células epidérmicas portadoras de corpos silicosos. Segundo Smith (1971), Ananas ananassoides ocorre em terras pobres e sobre pedras, em condiçôes realmente xerofíticas;

- Streptocalyx poeppigii e Aechmea setigera estão bem adaptadas estruturalmente ao hábito epifítico e podem se desenvolver bem na cam- pina, pois, ainda que não tenham escamas muito especializadas para a absorção de água, têm condições de coletar água da chuva, armazenando-a na base das folhas e evitando transpiraçäo excessiva através de estômatos cobertos por escamas. Como epífitas, não são muito especializadas, por serem plantas grandes, com folhas espessas. Possuem ainda um número de estômatos em relação ao de escamas muito grande, em comparação com Ananas ananassoides, que é terrestre:

- Tillandsia adpressiflora e Vriesea splitgerberi mostram caracteres anatômicos muito evoluídos, principalmente pela diferenciação estrutural e, provavelmente, funcional das escamas;

- Aechmea mertensii parece ser uma das espécies mais adaptadas às condições em que se encontra, pois sem possuir proteção de escamas sobre os estômatos, ocorre em grande escala. Tem uma diferença principal das outras espécies: as projeções laterais esclerificadas, que obstruem a entrada da câmara subestomática.

Todas as espécies vivem bem na campina. Se alguma espécie possui adaptações anatômicas especiais para este ambiente, não foi possível verificar devido à falta de elementos para comparação. Seria interessante para o futuro fazer análise semelhante de indivíduos dessas mesmas espécies, que fossem encontrados em ambientes diferentes. 


\section{$S U M M A R Y$}

A study was made of the leaf anatomy of six species of Bromeliaceae found in an Amazonia campina. An attempt was made to correlate anatomical structure with the campina enviranment.

Six species were studied: Aechmea mertensii (Meyer) Schult., Aechmea setigera Mart. ex Schult., Ananas ananassoides (Baker) L. B. Smith, Streptocalyx poeppigii Beer, Tillandsia adpressiflora Mez e Vriesea splitgerberi (Mez)

L. B. Smith \& Pittendrigh.

Leaves from the rosette periphery were removed and histological sections were prepared of four regions of each leaf: base-middle, center-middle, marginal-middle and apicalmiddle.

The epidermis was dissociated from six regions of the leaves: base-middle, basemargin, center-middle, center-margin, apex-middle and apex-margin.

Scales were obtained by scraping the leat surface in the same six regions used for the epidermal dissociations. Fresh sections were made to test for starch and for a better understanding of the structures.

Descriptions of the structures, photo. micrographs and schematic drawings were made using the material thus obtained.

Also, the number of stomata and the scales were counted in the upper and lower epidermis.

In the six species studied, the epidermal structure was found to be typical of the Bromeliaceae: "Epidermal cells in surface view with markedly sinuous walls; inner wall much thicker than outer, each cell usually including a large silica-body" (Tomlinson, 1969).

The smallest cells were observed in Ana. nas ananassoides and Streptocalyx poeppigii. The other four species presented small epidermal cells only at the leaf base.
It can be said, based on the data obtained, that the number of scales within a single leaf seemed to influence the size of the cells within that leaf.

in general, the anticlinal walls of the cells were sinuous. This may be related to the amount of humidity. The thickness of the internal anticlinal and periclinal walls may be related to the temperature and light found in the campina.

The occurrence of silica-body was more or less constant. Silica-bodies were not observed regularly in the middle and apical regions of the leaves of Vriesea splitgerberi and Aechmea setigera.

Scales in rows were found throughout the leaf on the upper epidermis of Ananas ananassoides and Streptocalyx poeppigii, while in Aechmea setigera, Aechmea mertensii and Vriesea splitgerberi scales in rows were found in the middle and apical regions only. In Tillandsia adpressiflora scales were not arranged in rows on any part of the leaf.

The largest number of scales were found in the basal region for all species examined.

The structural specialization of scales was observed primarily in Tillandsia adpressiflora and Vriesea splitgerberi.

Ananas ananassoides, Streptocalyx poeppigii, Aechmea setigera and Vriesea splitgerberi had scales and stomata distributed in bands in the middle and apical region of the leaf. At the base the scales and stomata were found in rows. The stomata and scales in Aechmea mertensii were always in rows, while in Tillandsia adpressiflora their distribution was irregular.

In Aechmea mertensii and Vriesea splitgeıberi were the stomata not covered by scale shields. In the other species, scales probably help to avoid water-loss through the stomata. 
Projections of the lateral cells of the supstomatic chamber occured in such a way as to almost close it. In Aechmea mertensii these projections were completely sclerified.

The number of stomata increased from the base of the leaf to the apex. This was found to be true for all species studied.

The ratio of stomata number to number of scales was greatest in Aechmea mertensii while in Tillandsia adpressiflora it was the lowest. According to Tomlinson (1969) the ratio is greatest in terrestrial plants and least in epiphytes.

In Aechmea mertensii the stomata were not structurally and functionally related with scales, which may be because this species is an epiphyte and nas a high ratio of stomata to scales.

In Aechmea setigera, Ananas ananassoides and Streptocalyx poeppigii it was observed that the superficial layers of cells were sclerified. in Tillandsia adpressiflora and Vriesea splitgerberi sclerotics layers were found only beneath the lower epidermis.
In Ananas ananassoides and Aechmea mertensii the aquiferous parenchyma was well developed. In the other species the chlorenchyma also seemed to have a water storage function.

Sclerotic fibers re-inforce the leaves of Ananas ananassoides, Streptocalyx poeppigii. Aechmea setigera and Vriesea splitgerberi.

Branched parenchyma celis were more highly developed in the leaves of Tillandsia adpressiflora and Vriesea splitgerberi.

The vascular strands in all species showed a variation in size and fiber reinforcement.

The base of the leaves were observed to function as specific starch storage areas.

The structural conditions of all the species which were studied are such as to allow them to live in the campina environment, however. due to insufficient data it was impossible to verify that these structures were specific to the campina environment. 
BAUMERT, $K$.

1907 - Physiologische Bromeliaceen-studien. III - Experimentelle Untersuchungen über Lichschutzeinrichtungen an grünen Blät. tern. Inaug. Diss. Erlangen, apud Krauss, B. H. - Anatomy of the vegetative organs of the pineapple, Ananas comosus (L.) Merr. II. The leaf. Bot. Gazette, 110(3) : 333-404. 1949.

DE BARY, A.

1884 - Comparative Anatomy of the Vege. tative Organs of the Phanerogams and Ferns. Clarendon Press, Oxford, apud Krauss, B.H. - Anatomy of the vegetative organs of the pineapple, Ananas comosus (L.) Merr. II. The leaf. Bot. Gazette, 110 (3) : 333-404. 1949.

Krauss, B.H.

1949 - Anatomy of the vegetative organs of the pineapple, Ananas comosus (L.) Merr. II. The leaf. Bot. Gazette, 110(3): 333-404

LINSBAUER, $\mathrm{K}$.

1911 - Zur physiologischen Anatomie der Epidermis und des Durchlüftungsapparates der Bromeliaceen. Sitzungsber. Kais. Akad. Wiss. Wien (Math.-naturwiss. Klasse) 120:319-348, apud Klauss, B.H. - Anatomy of the vegetative organs of the pineapple, Ananas comosus (L.) Merr. II. The leaf. Bot. Gazette, 110(3): 333-404. 1949.

LISBÔA, P.

1975 - Estudos sobre a vegetação das Campinas Amazônicas - III. Observações gerais e revisão bibliográfica sobre as Campinas Amazônicas de areia branca. Acta Amazonica, Manaus, 5(3):211-223.

LIsBôA, R.

1975 - Estudos sobre a vegetação das Campinas Amazônicas - V - Brioecologia de uma campina amazônica. Acta Amazonica, 6(2):171-191.

Ribeiro, M.N.G. \& SANTos, A. DOS

1975 - Observações microclimáticas no ecossistema Campina Amazônica. Acta Amazonica, 5(2):183-189.

RICHTER, P.

1891 - Die Bromeliaceen vergleichend anatomisch betrachtet. Inaug. Diss. Berlin (Lubben), apud Krauss, B.H. - Anatomy of the vegetative organs of the pineapple, Ananas comosus (L.) Merr.
II. The leaf. Bot. Gazette, 110(3):333-404. 1949.

SASs, J.E

1951 - Botanical Microtechnique. Iowa, the Iowa State College Press. 2. ed.: 1-228.

SCHIMPER, A.F.W.

1888 - Botanisch Mittheilungen aus den Tropen. II. Die epiphytische Vegetation Amerikas. Jena, Gustav Fischer, apud Krauss, B.H. - Anatomy of the vegetative organs of the pineapple, Ananas comosus (L.) Merr. II. The leaf. Bot. Gazette, 110(3):333-404, 1949.

SМтTH, L.B.

1971 - Flora de Venezuela. Bromeliaceae. Caracas, Inst. Bot. Caracas, 12(1):1-361.

SOLFREDER, H. \& MEYER, F.J.

1929 - Bromeliaceae in Systematische Anatomie der Monokotyledonen, Berlin, 80-129, apud Krauss, B.H. - Anatomy of the vegetative organs of the pineapple, Ananas comosus (L.) Meer. II. The leaf. Bot. Gazette, 110(3):333-404. 1949.

TIETZE, M.

1906 - Physiologische Bromeliaceen-studien II. Die Entwicklung der wasser-aufnehmenden Bromeliaceen-Trichome, $\boldsymbol{Z}$. Naturw., 78:1-51, apud Tomlinson, P.B. - Anatomy of the Monocotyledons. III. Commelinales-Zingiberales. Oxford, Oxford University Press: 193-294. 1969

TOMLINSON, P.B.

1969 - Anatomy of the Monocotyledons. III. Commelinales-Zingiberales, Oxford, Oxford University Press: 193-294.

WITTMACK, L.

1888 - Bromeliaceae in Engler and Prantl's Die naturlichen Pflanzen-familien, 2(4): 32-59, apud Krauss, B.H. - Anatomy of the vegetative organs of the pineapple, Ananas comosus (L.) Merr. II. The leaf. Bot. Gazette, 110(3): 333-404. 1949 .

Yoshida, S.; OHNIShI, Y. \& Krtagishi, K.

1962 - Histochemistry of silicon in the rice plant, III. The presence of a cuticle-silica double layer in the epidermal tissue. Soil. Sci. Pl. Nutr., 8(2):1-5, apud Sangster, A.G. e Parry, D.W. - Silica deposition in the Grass Leaf in Relation to Transpiration and the Effect of Dinitrophenol, Ann. Bot., 35:667-677. 1971. 